Florida International University FIU Digital Commons

8-13-1996

\title{
The effects of Chinese painting appreciation education on the artistic achievement of junior high school students in Taiwan
}

Hsiu-Hsiung Chen

Florida International University

DOI: $10.25148 /$ etd.FI14060163

Follow this and additional works at: https://digitalcommons.fiu.edu/etd

Part of the Curriculum and Instruction Commons

\section{Recommended Citation}

Chen, Hsiu-Hsiung, "The effects of Chinese painting appreciation education on the artistic achievement of junior high school students in Taiwan" (1996). FIU Electronic Theses and Dissertations. 2131.

https://digitalcommons.fiu.edu/etd/2131 
FLORIDA INTERNATIONAL UNIVERSITY

Miami, Florida

THE EFFECTS OF CHINESE PAINTING APPRECIATION EDUCATION ON THE ARTISTIC ACHIEVEMENT OF JUNIOR HIGH SCHOOL STUDENTS IN TAIWAN

A dissertation submitted in partial satisfaction of the requirements for the degree of DOCTOR OF EDUCATION

in

CURRICULUM AND INSTRUCTION

by

Hsiu-Hsiung Chen

1996 
To: Dean I. Ira Goldenberg

College of Education

This dissertation, written by Hsiu-Hsiung Chen, and entitled, The Effects of Chinese Painting Appreciation Education on the Artistic Achievement of Junior High School Students in Taiwan, having been approved with respect to style and intellectual content, is referred to you for judgment.

We have read this dissertation and recommend that it be approved.

Paul A. Rendulic

$\overline{\text { Judith J. Slater, Co-Major Professor }}$

$\overline{\text { Stephen M. Fain, Co-Major Professor }}$

Date of Defense: August 13, 1996

The dissertation of Hsiu-Hsiung Chen is approved.

Dean I. Ira Goldenberg

College of Education

Dr. Richard L. Campbell

Dean of Graduate Studies

Florida International University, 1996 
COPYRIGHT $₫ 1996$ by Hsiu-Hsiung Chen

All rights reserved 
I dedicate this dissertation to my family whose support enabled me to complete this dissertation. 


\section{ACKNOWLEDGMENTS}

I would like to express my thanks to the committee members of this

dissertation. Dr. Stephen M. Fain and Dr. Judith J. Slater always provided me with time, modified my dissertation draft with patience and encouragement. I would like to thank Dr. Paul Rendulic, who was willing to help me many times to guide me through the statistical analysis required by this study. I wish to thank Dr. Thomas K. Skalko for guiding me in this study's special field.

I would like to thank so many people for the inspiration and support they provided me with as I persevered to complete this dissertation. To Professor Feng-Mei Kang, the professor at National Taiwan Normal University, Professor Mao-Sen Liang, the professor at National Kaohsiung Normal University, thank for their help and encouragement.

Greatest thanks to my mother, brothers, sisters, my daughters and sons, and especially my wife, for their continued support, encouragement and contributions. Thanks to you all. Then I wish to thank many other persons: my relatives and friends. They always supported and provided for me, too. Thank you so much again. 


\section{ABSTRACT OF THE DISSERTATION \\ THE EFFECTS OF CHINESE PAINTING APPRECIATION EDUCATION \\ ON THE ARTISTIC ACHIEVEMENT OF JUNIOR HIGH SCHOOL STUDENTS \\ IN TAIWAN \\ by \\ Hsiu-Hsiung Chen}

For the Chinese, fine art is one of the most important items in human life. The goals of fine arts education enhance the student so that s/he can make reasonable judgments about work, gain knowledge of color and understand the process of designing environmental layouts. Related technique and creativity training are offered students in accordance with individual differences and social expectations.

Traditionally, Taiwan's junior high school fine art program teaches mainly painting technique. The Ministry of Education in Taiwan determines the curriculum of junior high school fine art education. The purpose of this study was to determine the effects of teaching Chinese painting appreciation on the artistic achievements of junior high school students in Taiwan. The subjects were seventh grade students who had never learned Chinese painting before. Two classes were randomly chosen from each target school and were designated as the experimental or control group. Instruction in all groups was delivered by the researcher himself. At the end of the study, data about subjects' related knowledge, creative technique, and feeling toward Chinese painting were systematically collected and analyzed. 
The result of the study was that students in the experimental group were more motivated to learn Chinese painting than were the students in the control group.

Students in the experimental group made better progress in the development of creative skill, had better critical ability, and demonstrated better performance in Chinese painting form, set up, stroke and color of related knowledge than did students in the control group. It was therefore concluded that Chinese painting appreciation education can promote better artistic achievement and that this approach should be used in other areas of art education. 


\section{TABLE OF CONTENTS}

CHAPTER ONE: INTRODUCTION $\ldots \ldots \ldots \ldots \ldots \ldots \ldots \ldots$

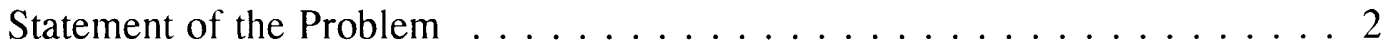

Statement of the Purpose . . . . . . . . . . . . . . . . 3

The Research Questions and Hypotheses . . . . . . . . . . . . . . . 3

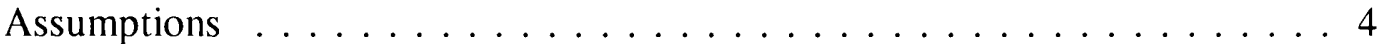

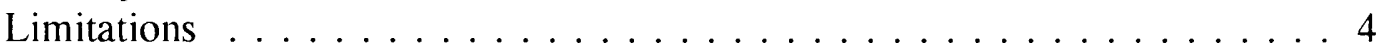

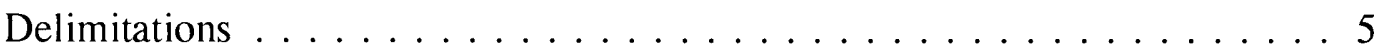

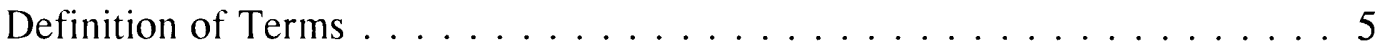

Summary ....................... 6

CHAPTER TWO: REVIEW OF THE LITERATURE . . . . . . . . . . . 9

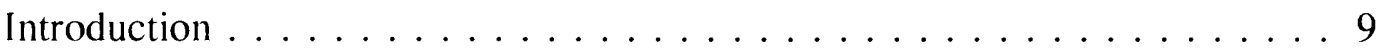

Basic Theories in the Learning of the General Arts . . . . . . . . . . . . 9

The Psychological Aspect . . . . . . . . . . . . . . . 10

The Aesthetic Aspect . . . . . . . . . . . . . . . . . . . 15

Eisner and the Relationship Between Art and Psychology . . . . . . . . 17

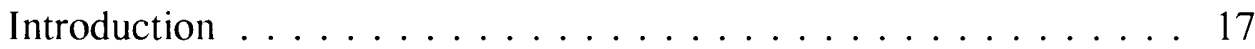

Theory of Six Methods of Hsieh Ho . . . . . . . . . . . . 20

Course of Chinese Painting . . . . . . . . . . . . . . . 23

The Allocation of Teaching Hours . . . . . . . . . . . . 24

Summary . . . . . . . . . . . . . . . . . . . . . . 29

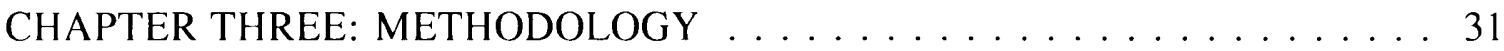

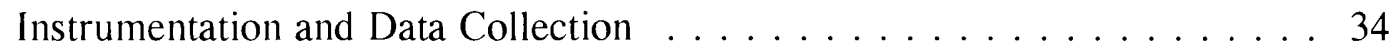

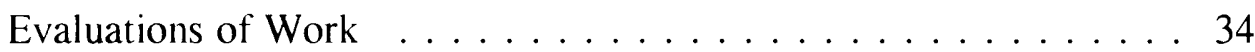

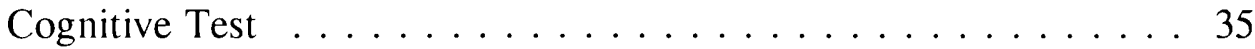

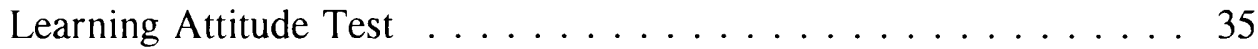

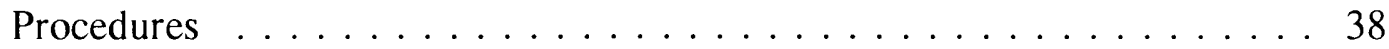

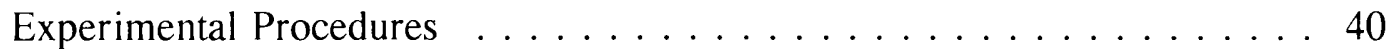

Preparation Stages . . . . . . . . . . . . . . . 40

Administrative Coordination and Pre-Learning Tests . . . . . . . . 40

Experiment in Process . . . . . . . . . . . . . . 41

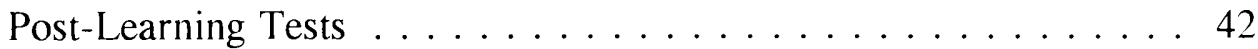

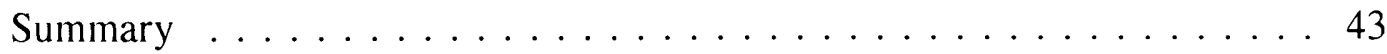

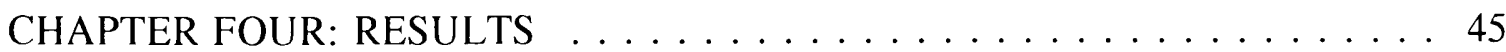

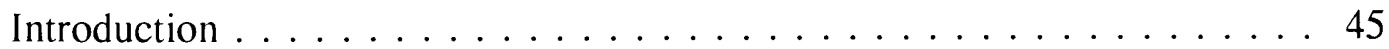

Results of the Pretest and Posttest of Student Art Work . . . . . . . . . 46

Pretest Art Work Result . . . . . . . . . . . . . . 46

Posttest Art Work Result . . . . . . . . . . . . . . . . . . . . 48 
Knowledge Achievement ................ 51

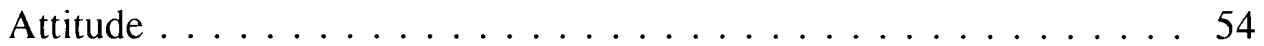

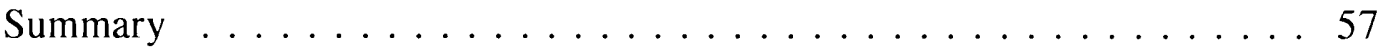

CHAPTER FIVE: RESULTS AND RECOMMENDATIONS . . . . . . . . . . . 59

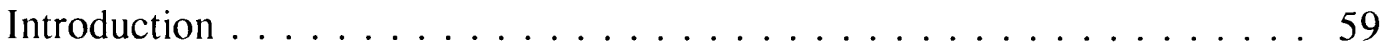

Conclusion ....................... 63

Recommendations for Further Study . . . . . . . . . . . . . . . . 64

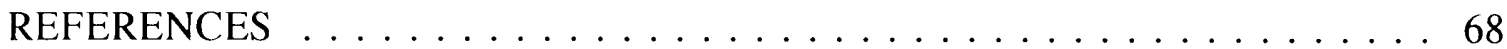

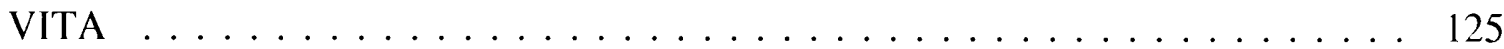

APPENDICES:

A: Design List of Teaching Activities for Traditional Painting Skills:

First School Year, Control Section . . . . . . . . . . . . . . . 72

B: Design List of Teaching Activities for Traditional Chinese Painting:

First School Year, Control Section . . . . . . . . . . . . . . . 78

C: Activity Table for the First Year Student Experimental Group

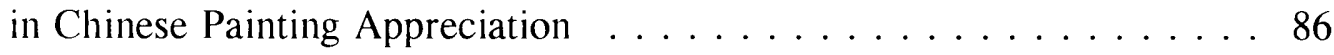

D: The Posttest of Knowledge . . . . . . . . . . . . . . . 105

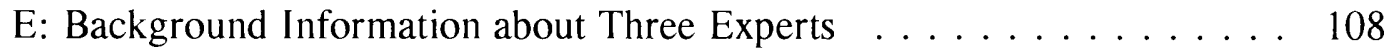

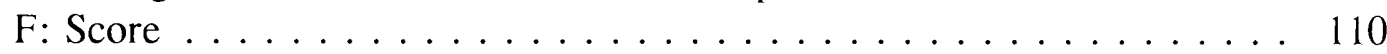

G: The Works of Students . . . . . . . . . . . . . 117

TABLES:

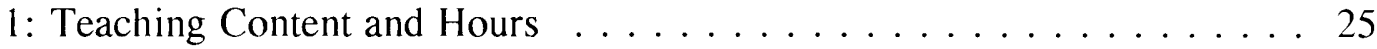

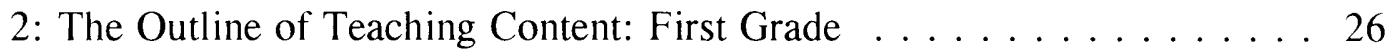

3: The Outline of Teaching Content: Second Grade . . . . . . . . . . . . 27

4: The Outline of Teaching Content: Third Grade . . . . . . . . . 28

5: Students' Distribution of Each Group . . . . . . . . . . . . . 32

6: Analysis of Number of Students . . . . . . . . . . . . 33

7: Means and Standard Deviations- Pretest Art Work . . . . . . . . . 47

8: Oneway Analysis of Variance- Pretest Score . . . . . . . . . . . . 47

9: Means and Standard Deviations- Posttest Art Work . . . . . . . . . . . . 49

10: Factorial Analysis of Covariance-Quality of Art Work Posttest . . . . . 50

11: Results of Post Hoc Multiple Comparisons Tests on Quality of Art Work

Posttest by School . . . . . . . . . . . . . . . . . . 51

12: Means and Standard Deviations of Tests of Knowledge by Group . . . 52

13: Analysis of Variance Tests of Significance for Knowledge Using Unique Sums of Squares 
14: Means and Standard Deviations- Students' Attitude . . . . . . . . 55

15: Analysis of Covariance of Students' Attitude Toward Art . . . . . . 56

16: Results of Three Posttests . . . . . . . . . . . . . . . 58

17: The Combined Mean of Two Tests of Each Group . . . . . . . . . . 61

\section{FIGURES:}

1: The Comparisons between Child Development Theories of Piaget,

Lowenfeld and Eisner . . . . . . . . . . . . . . . . 11

2: Designed Experimental Model . . . . . . . . . . . . . . 39

3: The Teaching Schedules for Each Group . . . . . . . . . . . . . 43

4: Interaction Effect on Student Knowledge Group by School . . . . . . . 54

5: Interaction Effect- Attitude Group by School . . . . . . . . . . . 57 


\section{CHAPTER ONE}

\section{INTRODUCTION}

In recent years, many art educators have advocated the importance of art appreciation education (Chao, 1989; Wang, 1992). At the same time, they also proposed appreciation as the main theme of art education. The reason behind this is because art education in the past for elementary and high school students has been focused mainly on creation instead of cultivating the capability for art appreciation. That is to say, the development of art appreciation has not been taken seriously. As Eisner (cited in Wang, 1986, p.202) advocated, art curricula must include three levels of learning: (1) creation, (2) evaluation, and (3) culture. Art learning mainly develops the student's: (1) capability to create art forms, (2) sense of beauty, and (3) ability to understand art through cultural phenomena. Moreover, there are the four art learning areas expressed by the Discipline-Based Art Education (DBAE) (Chao, 1989, p.5) in the United States. They are: art creation, art history, art evaluation and aesthetics (Wang, 1990, p. 194).

Art history, art evaluation and aesthetics are all related to art appreciation. We can see that in addition to learning how to create, a complete art curriculum must also include learning how to appreciate. These two must complement each other without partiality. Especially during the creation process, appreciation skills provide the creator with more perception on media, materials and techniques. These complicated 
wondrous feelings, so important in art, cannot be expressed verbally, so the creation process is one way of developing the ability to appreciate. On the other hand, art appreciation can also act as the foundation for developing the students' artistic creativity. In other words, "appreciation" is the necessary condition for sensing beauty, analyzing form correlation, and judging self-creations for students involved in creative activities (Huang, 1993, pp.83-104). Aside from learning creative techniques, it is even more necessary to have a rich foundation of art knowledge in the background so that creative education will not be limited only to the development of the ability to "produce," or to the provision of sparse knowledge on topics related to art. Appreciation is essential if there is to be advancement in the quality of creation. Therefore this study proposes to investigate the differences in affective and cognitive learning and product creation resulting from teaching Chinese painting appreciation.

\section{Statement of the Problem}

Art education is required in the curriculum of Junior High School throughout Taiwan. This course is taught in accordance with traditions and customs which are ancient in origin. It may be that the ancient approach worked well when it was developed. However, today students in modern schools in Taiwan are forced to learn many new subjects and the focus tends to be on learning specific skills rather than acquiring cultural understanding. 
The purpose of this study was to raise the question of the impact of cultural and artistic appreciation on both learning and skill development of contemporary students in Taiwan. This study was directed toward considering the impact of the teaching of Chinese art and culture in the modern Junior High School in the area of Chinese painting.

\section{Statement of the Purpose}

This study investigated the differences in artistic preference between Taiwanese Junior High School students who received art appreciation instruction concerned with skill and technique instruction as compared to students who only received skill and technique instruction.

\section{The Research Questions and Hypotheses}

The following research hypotheses were the focus of this study:

1. There will be a significant difference in the art works (painting works) produced by Taiwan Junior High School students who receive instruction in Chinese painting appreciation as compared with students who do not receive this instruction.

2. There will be significant differences in art achievement (knowledge) between Taiwan Junior High School students who receive instruction in Chinese painting appreciation as compared with students who do not receive this instruction. 
3. There will be significant differences in the attitude towards art between Taiwan Junior High School students who receive instruction in Chinese painting appreciation as compared with students who do not receive this instruction.

\section{Assumptions}

It is assumed that Chinese painting is an integral part of ancient Chinese culture and as such the effective teaching of Chinese painting is significant in the education of young Chinese students.

It is further assumed that serious consideration will be given to modern approaches to teaching if they can be shown to be effective in teaching modern and ancient subjects.

Finally, it is assumed that teachers of Chinese art in Taiwan in particular will be very interested in finding more effective ways to teach their subjects.

\section{Limitations}

Because the intervention has been designed and implemented by an expert in the field of Chinese painting, results may not be replicable to other teachers of Chinese painting.

Given the status of the course instructor, a university professor of Chinese painting, a novelty effect must be considered when reviewing the findings of this study. 


\section{Delimitations}

The instructional materials used in this study by both the experimental and control groups were identical but were different from the materials normally available for teachers of Chinese painting at regular schools.

\section{Definition of Terms}

Color: It is the meaning of coloring or dyeing colors. In Chinese painting, colors are usually based on natural sceneries and objects. This is what one of Shieh Ho's six Laws meant by "Follow the type in giving color." The color in Chinese painting is based on black ink. Black ink can be various in exerting dry, wet, dark, light, or black so that there is a great variety of colors. These colors can be mixed by using water or resin on the brush or palette (Chen, 1988, p. 152).

Form: It is the drawing of form. Form is the center of Chinese painting. It depicts the life as well as styles of painting. The former includes objects, and the latter is more significant. Form itself is a combination of life and form (Chen, 1988, p. 45). Gongbi: Use of different light black lines to draw objects without other colors.

Nothing but light ink coloring is allowed; otherwise, you may use lines to draw the outlines of the object and then add colors.

Pen strokes: It is the method of using the pen. In Shieh Ho's 6 Laws, the "Using the Pen by Bones" (Chen,1988, p.74) explained its importance. For example, the different 
strokes used in mountain and water paintings, and human paintings are expressions of different methods for drawing strokes.

Set Up: It is the structure diagram and refers to the selection and combination of scenery and object seen to be expressed in the painting after thinking. This is the "selling point" (Chen, 1988, p. 29) referred to in Shieh Ho's Six Laws. In the set up arrangement, one must pay attention to distance, realism, main object, overlap, and direction.

Xieyi: Use of colors to form and draw directly without using lines, or to describe the form, structure and meaning of the object by using simple strokes to draw expressions.

\section{Summary}

Man is a lover of beauty. After satisfying his need for material fulfillment, he will look for higher living quality. As modern psychologist Maslow (Good, \& Brophy, 1990, pp.364-365) pointed out, man's instinct for life is based on his survival (both physical satisfaction and personal security) and then he who secures the fundamental requirements will further search for knowledge and art (beauty). That is when a person's survival needs are fulfilled; he will long for higher living and art standards. But art activities are passed to the viewers in forms, symbols and media materials, and the viewers, in turn, experience the beauty inspired by the creators through art activities or objects. The experience of beauty is lastingly stable, relatively self-fulfilling and widespread in nature. These characteristics must be perfected through 
education. The most important thing in the education of beauty appreciation is to motivate the students to search for experience in sensing beauty, that is, the interactive experience with art objects for spiritual satisfaction and value. It covers the experience in appreciating art objects and guides the viewer's value in enjoying the sense of beauty. With the emphasis on the sense of beauty, education in art appreciation is widely recognized by scholars. Its importance in art education is significantly necessary.

Chinese painting, the oldest living art in the world, has much to offer artists and art lovers in both the east and west. Rooted in a rich tradition of over two thousand years yet exceedingly contemporary, Chinese art possesses a beauty that transcends time which signified cultivation from the environment and preoccupied resources from your mind. A celebration of nature, Chinese painting is orderly yet mysterious, reflecting its source. The highly developed principles and refined techniques, so ingenious and so logical, are totally absorbing and always fascinating. This is due to the similar origins between literature and painting from ancient Chinese society which united lyrical description and exertion of calligraphy to react and distinguish the influence of art characteristics. Pen, ink, paper, color, ink-slab, and so on are the tools and materials which are used in drawing and Chinese painting especially (China Artistic Dictionary Compiler Committee, 1987, p. 3).

In Chinese painting, nature provides the wellspring of inspiration. Its infinite variety of forms and patterns are unsurpassed. "Many of the subjects have acquired 
symbolic significance through the ages, thus further contributing to their wealth of meaning" (Yu, 1981, p.1). Therefore, students as part of their education, should be exposed to the elements and techniques of Chinese Painting. 


\section{CHAPTER TWO \\ REVIEW OF THE LITERATURE \\ INTRODUCTION}

Both curriculum development and teaching methods are aimed at proving students learning. Therefore, the theories of each must be based, at least in part, on an understanding of students knowledge of art curriculum and teaching theory. Since this study focused on the teaching and learning of art, this review will begin by establishing a theoretical base. To this end this review will analyze general theories of teaching and learning and then present an analysis of Eisner's view on learning art and Shieh Ho's Six Laws of Chinese Painting which has been famous for about two thousand years originating in ancient China. Finally, the standards of fine art in Junior High School from the Ministry of Education in Taiwan will be presented.

\section{Basic Theories in the Learning of the General Arts}

There are two aspects to the basic theories surrounding artistic creativity and learning ability of children: 1 . The psycho-analysis of the artistic development in children and its accompanying learning psychology; 2. The study of artistic characteristics and its educational functions from the aesthetic point of view. At present, there are numerous art educators who promote the integration of the two aspects in the establishment of the theories in the learning of the arts. 


\section{The Psychological Aspect}

One basic approach to the question of how children learn is found in cognitive theory. This theory explains that children sketch what they know and as the cognitive abilities of children are immature, therefore, they cannot fully express the form of their subject. When a child's learning matures and gains abundant ideas, his artistic expression becomes more vivid, complicated and accurate (Feldman, 1970, pp. 131-132).

Another school of thought advocates a developmental approach. Piaget, Lowenfeld and Eisner each advocate a developmental basis for teaching and learning art. In fine art education, there are disagreements among the learning theories. The comparisons of those key points of Piaget's cognition theory, Lowenfeld's development theory, and Eisner's fine art learning theory are depicted in Figure 1.

Piaget divided the procedure of child cognition development into four stages. The fourth stage is the formal operation stage, equivalent to twelve to fifteen years of age. Piaget believed that the child in this stage is able to imply hypothesis and abstract thinking and to demonstrate cognition and reasoning. Lowenfeld (cited in Feldman, 1970, pp. 143-147) divided child development in fine art into five stages. His fifth stage is called Pseudo-naturalistic stage, equivalent to age of twelve to fourteen. Lowenfeld concluded that children in this stage move into the time of reasoning and start criticizing their own works. 


\begin{tabular}{|c|c|c|c|c|}
\hline AGE & PIAGET & LOWENFELD & EISNER & $\begin{array}{l}\text { EDUCATION } \\
\text { LEVEL }\end{array}$ \\
\hline 1 & \multirow[b]{2}{*}{ Sensorimotor } & & & \\
\hline 2 & & \multirow[t]{3}{*}{ Scribbling } & \multirow{3}{*}{$\begin{array}{l}\text { Function- } \\
\text { Pleasure }\end{array}$} & \\
\hline 3 & \multirow{5}{*}{ Preoperational } & & & \\
\hline 4 & & & & \\
\hline 5 & & \multirow{3}{*}{ Preschematic } & \multirow{5}{*}{ Pictographs } & Preschool \\
\hline 6 & & & & \\
\hline 7 & & & & \multirow{6}{*}{ Elementary } \\
\hline 8 & \multirow{4}{*}{$\begin{array}{l}\text { Concrete } \\
\text { Operations }\end{array}$} & Schematic & & \\
\hline 9 & & & & \\
\hline 10 & & Drawing & \multirow{5}{*}{$\begin{array}{l}\text { Representa- } \\
\text { tional }\end{array}$} & \\
\hline 11 & & Realism & & \\
\hline 12 & \multirow{4}{*}{$\begin{array}{l}\text { Formal } \\
\text { Operations }\end{array}$} & \multirow[t]{2}{*}{ Pseudorealistic } & & \\
\hline 13 & & & & \multirow{3}{*}{ Junior High } \\
\hline 14 & & \multirow{4}{*}{ Decide } & & \\
\hline 15 & & & \multirow{6}{*}{$\begin{array}{l}\text { Aesthetic- } \\
\text { Expressive }\end{array}$} & \\
\hline 16 & & & & \multirow{3}{*}{ Senior High } \\
\hline 17 & & & & \\
\hline 18 & & & & \\
\hline 19 & & & & \\
\hline 20 & & & & \\
\hline
\end{tabular}

Figure 1. The comparisons between child development theories of Piaget, Lowenfeld, and Eisner (Chao, 1989, p. 62). 
According to Liu (1987, pp. 90-124), Eisner divided the child's development in fine art performance into four stages. Children ages ten to fourteen are in what he calls the representation stage. In this stage the student's performance generally falls short of their unrealistic expectation and they are usually disappointed in their work.

We can conclude that there is a similar age range among Piaget's formal operation stage, Lowenfeld's pseudo-realistic stage, and Eisner's representational stage. From about ten to fifteen year of age the child is in this development. This is where he/she reaches the plateau period of his creative performance and rises to the sense of critic of art work. If we cannot provide students with meaningful fine art programs, then these students will lose their interest in fine art courses (Wang, 1975, pp. 23-26).

To avoid the problem of loss of interest mentioned above, Broudy (Chao, 1989, pp.49-73) suggests that at this specific period fine art education should emphasize instruction in impression skills rather than in expression skills; that the curriculum should emphasize fine art appreciation and/or criticism. Teachers should provide students with opportunities to describe, analyze, and evaluate fine art works to learn the forming structure and content demonstration of a fine art work as well as to meet their cognitive needs (Hardiman \& Zernich, 1981, pp. 171-190). Only when these efforts are done well can we overcome the myth that the goal of fine art education is to create skilled painters. The highest goals of fine art education are to shape humanity, strengthen human potential, and contribute resultant expertise to the nation and society. 
Another theoretical basis for art education is found in psychological theory. Our spiritual activity includes conscious and subconscious parts. The former one is practical and rational thinking and behaviors. In other words, our daily activity is controlled by a conscious ego so our behaviors are compliant with moral standards and decorums. The subconscious id is presumed full of erotic desires but repressed by the conscious ego. Though the desires are hidden in subconsciousness, the desires find their own satisfaction by replacement. Art is one kind of sublimation of subconscious desire and becomes one of the cultural styles (Read, 1956, pp. 171-188). From a psychoanalytical perspective, the motivation and intention of art performance comes from the subsconsciousness. Relief of the desires of id becomes the main source of abundant imagination and vivid expression. This theory presumes that artistic expression is the process in which the subconscious mind brings forth ideas to the conscious mind (Feldman, 1970, pp. 147-152).

Gestalt psychology (Ho, 1985, pp. 156-169) presumes that as man looks at an object, he does not perceive the object as a part of a whole, but as the entirety of his perception or the so called total images that the mind constructs (Feldman, 1970, pp. 152-156; Armheim, 1969, pp. 13-15). We learn from Gestalt Theory the principles of vision, conception, graph and earth, balance, groups, forms, motions and sense of space. It benefits not only art creation but art criticism or aesthetic analysis. According to the theory, the learners could become more sensitive and effective. How 
do people live a life? This is the question which drives humanistic psychology. Children have their need to express themselves and their creation concerns the relationship of their lives with nature and society. In this context art is seen as a vehicle which exposes the ritual of human experience and the expression of man's confrontation with reality. Humanistic psychology recognizes roles art plays in human activities and culture which supports the positive purpose, function and characteristics of art (Feldman, 1970, pp. 157-180).

The behavioristic theories postulate learning behaviors through stimuli and response. This classic theory has been examined and it is now understood that if the response elicited is strong, then this intensifies the connection between the stimuli and the response. This connection may demonstrate learning (Efland, 1979, pp. 22-23). Behaviors produced show that learning can be attained through imitation; for example, children would imitate the intonation or words while their parents are speaking. This applies to art where learners could also learn from their teachers about drawing skills and structures. It is one of the best methods for students to imitate and make progress.

Creative thinking is the highest level of man's spiritual activity. The creative products are the best achievements of mankind. Today most countries all over the world are intentionally cultivating creative students who are able to dedicate themselves to art creation instead of those who study art psychoanalysis. However, it is still at issue that the different definitions of creativity, level, certification and theories would lead to a different result (Liu, 1984, pp. 73-74). 
The different definitions of creativity reflect both interest and uncertainty in this area. Research emphasis includes: (1) emphasis on product, (2) emphasis on the process, (3) emphasis on the experience of creativity, and (4) emphasis on the quality of the problem rather than the solution.

The relationship between learning and thinking need further examination. Thinking is a goal of most education in free societies. The act of thinking is highly motivating and stimulating. It causes a person to clarify ambiguous ideas or problems. Many elements like wisdom, motion, character, family, school and social culture are relevant to creativity. It may be concluded that creativity is one comprehensive science of behaviorism. This creates personality, characteristics of thinking, the process of creativity and the finding of solutions for problems (Lin, 1983, pp.154-177). These are stimulations for molding our thinking, choosing the materials, and orienting our instruction.

\section{The Aesthetic Aspect}

Conceptions of reality and the nature of knowledge are age old issues begun with Plato and Aristotle, and continued by philosophers such as Concord, Schiller and Dewey. They all declared there is an undeniable relationship between art and education as well as the possibility for art appreciation to be a function of education (Efland, 1979, pp. 52-60). 
What is Art? Tolstory indicated that the idea of art is sincerity, to transmit one's feelings, and it is infectious to improve children's art performance (Liu, 1984, p.75). This aesthetic view influenced art education in America. Efland (cited in Liu, 1984, pp. 75-76) makes the following observation: First, art is natural imitation which is considered a success only when the reproduction of the imitative objective is observed and comprehended to the audience. Second, the observers understand and are influenced through art works, their experience is conformed by the interaction between the characteristics of objects and the quality of observers. Third, art works are the expression of artists' feelings, which means art works come from artists' personality formation. Fourth, art works are independent unities, whose form exists paradoxically with complexity inside of unity. Nevertheless, Efland, analyzing aesthetics with psychological behaviorism, concluded that art is a natural imitation, however, learning is the change of behaviors through imitation and modification.

Objects of teaching also make a difference. A teacher should choose his/her own object early before the class and adjust the teaching methods according to the characteristics of the different classes. Therefore, there is not a definite perfect teaching method and verification of the teaching objects with teaching aids seems very important. Art is the expression of feelings; learning is the adjustment to society. Art is an independent unit; learning is the discovery of structure, separation, and unification (Efland, 1979, pp. 23-25). The above artistic research is based on Eisner's 
reunification of modern initial aesthetic and psychologic theories along with the ancient Chinese Shih Ho's Six Laws which will be discussed later in this chapter.

\section{Eisner and the Relationship Between Art and Psychology}

\section{Introduction}

Eisner integrates the principles of the study of art and psychology (cited in Liu, 1984, p. 77) . He builds on Gestalt theory as advocated by Anheimer and cognitive theory advocated by Piaget (cited in Liu, 1984, p.78). In the visual form of expression, Eisner mainly uses the theories of Anheimer and Langet (Liu, 1984, p.78). Eisner connects these theories with Dewey's Application Principle which states that artistic learning explains the special characteristics of artistic activity of a given moment in time.

In terms of development of artistic perceptual ability, Eisner believes that the principles of perceptual differentiation and visual generalization of the Gestalt theory is extremely important to the learning of the arts (Arnheim, 1968, pp. 29-76; Liu, 1984, p.78). He believes that the ability to differentiate quality improves with the maturity of a person; an adult person has a more complicated and sensitive perception compared to that of a child. This kind of visual generalization or visual concept can hinder a person's perception of the special characteristics of an object, a phenomenon called visual constancy. This condition often restricts a person's aesthetic perception. Eisner concurs with Philip Phenix's conception of schooling as a process that should help 
students to learn the application of different resource materials (Liu, 1984, p. 80; Eisner, 1972, pp. 66-69) . Eisner stated that artistic training is like other subjects, it has to be learned for there to be results. The teaching of arts, other than training skills, should help students develop their resource structures in order that they might expand their artistic ideas and know more art forms, thus enhancing their expressive ability.

Eisner, based on the Child Perception Theory of Piaget, states that a child's perception develops (Jean \& Inhelder, 1967; Liu, 1984, pp. 80-81). A child perceives one specific area only and cannot recognize the entire form and the relationship between a part and the whole. Eisner believes that there is a reciprocal relationship between the entirety of the art form or a part of it, and the other parts; if the artist lacks this consciousness, then it will cause the art piece to lack a sense of wholeness or integration. Eisner also considers the following experiences as influential factors that make or obstruct a perception: resource structures, mental set-up, expectations, perceptual constancy. These factors include education, individual feeling, environment, and so on. To overcome these difficulties, one depends on artistic education.

There are two opposing views, as far as art education is concerned, regarding the context of the visual forms expressed. First, students of the arts, e.g. Roger Fry and Clive Bell, tend to lean more on Formalism which is the aesthetic purity of the form and provides the principle of form integrity. Second, Eugene Veron, and Tolstory expostulate the Emotionalist Theory which stresses the subjectivity and 
emotionalism of the Content Connectivity (Liu, 1984, p.81; Stolnitz, 1960, pp. 134190). Eisner incorporated these two views and added Langet's view that a work of art is a form of expression, an expression of the human emotions, which emphasizes the importance of expressiveness (Eisner, 1972, pp. 71-79; Liu, 1984, p. 82).

Eisner also has a unique view of the characteristics of artistic activity (Eisner, 1972, pp. 113-114; Liu, 1984, p. 83). He believes that artistic activity is a form of intellect which people should learn to achieve. Adults and children alike need to use implements or tools, materials, or equipment to transform their thoughts, images or emotional problems; this also means the reciprocity existing in the treatment of form and context, as well as the creativity and control in the use of color, contour and shape. This form of visual art work is a type of intellectual perspective, that takes on deeper meaning when applied to the basic theories in artistic learning.

In conclusion, the following quotation captures Eisner's philosophy:

1.Visual art ability or skill is a result of a quality distinction of man and is a product of his education. Artistic ability needs to be developed with time; the educational process should be able to allow such skill or ability to flourish (Eisner, 1972, pp. 113-115; Liu, 1984, p. 84).

2. In learning the arts, one should pay attention to the intellectual characteristics of the art concerned and to delve more into learning to distinguish quality; these include: (a) Artistic activity has intellectual characteristics (Eisner, 1983, pp. 115-116); (b) Art is the unique form of expressing and comprehending meaning (Eisner, 1981, pp. 466- 
471); (c) Quality distinction is the foundation of the formation of an idea (Eisner, 1983, pp. 22-27; Liu, 1984, pp. 84-86). Eisner thus links art, education and intellectual activity in a way which provides a basis for art education.

\section{Theory of Six Methods of Hsieh Ho}

Hsieh Ho, of the Nan Chih dynasty, is one of the most famous ancient Chinese portrait painters who also demonstrated outstanding painting technique. Catalogs of Ancient Paintings, written by Hsieh (cited in Feng, 1988 p. 141), is the most valuable spiritual property left by remote ancestors and is considered the very first critical literature to exist in Chinese painting history. Hsieh systematically selected twenty seven famous painters from Three-Nation-State, 222 to 265 A. D., to the Nan Chih dynasty, graded their work, and pointed out their characteristics and shortcomings. This contribution to fine art criticism is held in the highest regard by all students of Chinese Painting. Supported by productive professional achievements, he presented a carefully crafted and significantly meaningful theory of Chinese painting. His six-method theory (Yu, 1987, pp. 54-61) outlines six criteria for judging a qualified work. The six criteria are: vigorous atmosphere, painting style and brush application, image to actual contour, color application, thoughtful layout, and imitative depiction. Those six criteria are the basis for the most important guide in criticism of Chinese painting. For more than one thousand years, fine art professionals have followed those six criteria when instructing learners in Chinese Painting. 
Before presenting his six-method theory, Hsieh said, "Although there are six criteria, it will not be easy for every individual painter to meet all of them"; he goes further, "Every work has its uniqueness"(Feng, 1988, p. 149). These statements exhibit Hsieh's objectivity. A painter who is able to achieve any one item of these criteria can earn himself on honorable reputation. These six criteria are simply criteria, not guides, for verifying the quality of a work. Their descriptions are very concrete and clear. Among these six criteria, the criterion of "vigorous atmosphere" is controversial because there are different interpretations of this; the other five criteria are commonly agreed by all schools.

A brief description of the six-method theory follows:

1. Vigorous atmosphere. It is the image drawing of an actual object. It gives a painting its life. If a painter wants to produce an authentic work, he needs to exhibit this characteristics in his work and to demonstrate it lively and naturally. Hsieh emphasized that this is the most important standard of Chinese painting because it is here where one finds the spirit of the work.

2. Painting style and brush application. For a good work, the brush application is appropriately light, heavy, slow, and/or speedy as needed, weighs both solidness and softness; and puts ink adequately, dense, light, dry, wet, or dark. This represents the central skill needed for Chinese painting.

3. Image drawing of actual objects. A painting has to be valid to the contour of its original object. This means a work must be realistic. 
4. Color application in view of a category. The color of an object differs according to its category. There are specific colors for different object categories. A qualified painter ought to learn this custom.

5. Thoughtful layout. The objects in a good work are placed appropriately. It is a matter of organization.

6. Imitative depiction. It is the duty of a beginner to come to those elegant works produced by previous famous painters as well as to study their brush application, color application, layout, and spiritual atmosphere. The work of the beginner will advance as his knowledge and understanding of previous famous paintings are learned and copied.

Vigorous atmosphere is an artistic effect created by innovative painters. Scholars explain that this criteria points out a talent, not a learned skill.

This researcher believes that there is an organic relationship between these six criteria. The presentation of these criteria is a most valuable contribution made by Hsieh Ho to the field of Chinese paining. The impact of his achievement is seen by studying all works produced by prestigious painters before and after him; collecting and analyzing all attainable related literature, as well as reflecting his own painting expertise. His influence is remarkable as the six-method theory was widely accepted and held in high esteem within the Chinese painting field. The six-method theory is not only the standard for brush manipulation production but also is the standard for criticism of fine art works. 


\section{Course of Chinese Painting}

Junior high schools are mainly established and operated by country/city and municipal governments. Since the nine-year fundamental (compulsory) education system was launched in 1968 , anyone who graduated from the elementary school (normally with age 12 or over) may be admitted to the junior high school without the requirement to pass any examination. A diploma is conferred on students upon graduation (Ministry of Education, 1995, p. 18).

Out of 716 junior high schools, only nine are run by private operators and the rest are under the jurisdiction of the government. Since the nine-year fundamental (compulsory) education program was launched in the school year 1968, the number of junior high schools has increased dramatically. Private junior high schools may continue their operation but are required to use the same curriculum and teaching materials as those of the public institutions. The ratio of students to teachers is $21: 1$ (Ministry of Education, 1995, p. 35).

The Goals of The Standards of Fine Arts Programs in Junior High School in Taiwan which are still in effect today are (Ministry of Education, 1983, pp. 160-162): To satisfy students' physical and mental development, to assist and guide their various activities of fine art, in order to cultivate students' independent thinking and creativity. To cultivate students' insights, imaginations, and the delight of self-fulfillment is accomplished through the fine arts education activities. Taking related daily life objects to mold students' character and beautify living habits through aesthetic 
creativity and appreciation is a goal. To encourage and guide students to recognize the outstanding tradition of Chinese arts in order to improve national spirit and consciousness, and increase the interests to enhance tradition is another goal. Using Fine Arts education to nourish morality education, intellect education, physical education, and social life education, and to advance students physical and mental balance and development, to enable them have harmonious, optimistic, reinvigorating, and enterprising lives is the overall purpose of the fine arts program in Junior High School in Taiwan.

\section{The Allocation of Teaching Hours}

The teaching hours for the first, second, and third grades of the Junior High School are one hour per week (basically arranged as two continual classes). These were established by the Ministry of Education in 1983 and continue to date. The categories of teaching content, grade and teaching hours are as follows (Ministry of Education): 
Table 1

Teaching Content and Hours

\begin{tabular}{|c|c|c|c|c|c|c|}
\hline \multicolumn{3}{|c|}{ Teaching Content } & \multicolumn{3}{|c|}{ Hours of Teaching } & \multirow[t]{2}{*}{ Note } \\
\hline & & & $\begin{array}{l}\text { First } \\
\text { Grade }\end{array}$ & $\begin{array}{l}\text { Second } \\
\text { Grade }\end{array}$ & $\begin{array}{l}\text { Third } \\
\text { Grade }\end{array}$ & \\
\hline & & $\begin{array}{l}\text { Chinese } \\
\text { Painting }\end{array}$ & 4 & 6 & 6 & \\
\hline & & $\begin{array}{l}\text { Water } \\
\text { color } \\
\text { Painting }\end{array}$ & 8 & 6 & 4 & $\begin{array}{l}\text { 1. To calculate, taking } 18 \\
\text { weeks per semester, the }\end{array}$ \\
\hline \multirow[t]{4}{*}{ Display } & Planes & $\begin{array}{l}\text { Sketch } \\
\text { Drawing }\end{array}$ & 4 & 4 & 0 & hours per year. \\
\hline & & $\begin{array}{l}\text { Engraved } \\
\text { Plate } \\
\text { Printing }\end{array}$ & 4 & 4 & 4 & \multirow{2}{*}{$\begin{array}{l}\text { 2. Arrange } 2 \text { continual classes } \\
\text { for every } 2 \text { weeks } \\
\text { as a principle. }\end{array}$} \\
\hline & & Design & 6 & 4 & 6 & \\
\hline & $\begin{array}{l}3- \\
\text { Dimen- } \\
\text { sions }\end{array}$ & $\begin{array}{l}\text { Sculpture } \\
\text { 3D } \\
\text { Forma- } \\
\text { tion }\end{array}$ & 4 & 4 & 6 & \\
\hline \multicolumn{3}{|c|}{ Appreciation } & 6 & 8 & 10 & \\
\hline
\end{tabular}


Table 2

The Outline of Teaching Content: First Grade*

\begin{tabular}{|l|l|l|l|}
\hline Categories & $\begin{array}{l}\text { Teaching } \\
\text { Content }\end{array}$ & Main Themes for Guidance & $\begin{array}{l}\text { Teach- } \\
\text { ing } \\
\text { Hours }\end{array}$ \\
\hline $\begin{array}{l}\text { Painting } \\
\text { Panes } \\
\text { 2. Ink } \\
\text { Colors }\end{array}$ & $\begin{array}{l}\text { 1. Drawing } \\
\text { painting. } \\
\text { 2. Use Chinese traditional brushes, ink, and } \\
\text { cotton paper as materials; inspire the students } \\
\text { to apply basic techniques, enable them to } \\
\text { realize the effects of ink, including dry and } \\
\text { wet, dark and light, spotty and spread; allow } \\
\text { them to have relaxed, vivid, and free mood to } \\
\text { learn Chinese painting. } \\
\text { 3. Use daily lives motion or static objects as } \\
\text { subjects to guide the students to observe and } \\
\text { research, practice the paintings from life, and } \\
\text { enjoy applying simple drawings of brushes and } \\
\text { ink to summarize presenting objects. }\end{array}$ & 4 & \\
\hline $\begin{array}{l}\text { Apprecia- } \\
\text { tion }\end{array}$ & $\begin{array}{l}\text { 1. At anytime pay attention to the beauty of } \\
\text { the nature and human bodies formation, enable } \\
\text { the students to realize the beautiful styles of } \\
\text { contrast, harmony, pace, portion, repetition, } \\
\text { color increasing, symmetry, balance, unity, } \\
\text { and pure. Furthermore, inspire their passion of } \\
\text { painting. } \\
\text { 2. Appreciate the works from Chinese and } \\
\text { foreign junior high school. Enable the students } \\
\text { to realize every work reflects its own unique } \\
\text { nationalism in order to establish the students' } \\
\text { accurate aesthetical concepts. } \\
\text { 3. Introduce modern themes and new } \\
\text { techniques of Chinese painting, enable the } \\
\text { students to understand the extensions of } \\
\text { traditional Chinese painting and its } \\
\text { combination with the modern spirit. }\end{array}$ & 28 & \\
\hline
\end{tabular}

*(Ministry of Education, 1983, p. 165) 
Table 3

The Outline of Teaching Content: Second Grade*

\begin{tabular}{|l|l|l|l|}
\hline Categories & $\begin{array}{l}\text { Teaching } \\
\text { Content }\end{array}$ & Main Themes for Guidance & $\begin{array}{l}\text { Teach- } \\
\text { ing } \\
\text { Hours }\end{array}$ \\
\hline $\begin{array}{l}\text { Chinese } \\
\text { Painting }\end{array}$ & $\begin{array}{l}\text { 1. Painting } \\
\text { Techniques } \\
\text { 2. Color } \\
\text { 3. Layout }\end{array}$ & $\begin{array}{l}\text { 1. Briefly introduce the applying nature of the } \\
\text { colors of Chinese painting. } \\
\text { 2. Guide the students to learn the traditional } \\
\text { techniques of painting and color mixing; } \\
\text { understand the basic concepts of Chinese } \\
\text { painting. Under Chine painting's sincere and } \\
\text { pure atmosphere, control theme and simplify } \\
\text { background, and introduce the general rules } \\
\text { for layout. } \\
\text { 3. Use daily lives objects to present a theme. } \\
\text { Watercolor for setting is allowed, but make } \\
\text { sure it goes with the basic ink, not being too } \\
\text { exaggerated or too colorful. }\end{array}$ & 6 \\
\hline Appreciat- \\
ion & $\begin{array}{l}\text { 1. Compare the color and formations between } \\
\text { nature and artificial objects. Use the realization } \\
\text { as a reference for creativity. } \\
\text { 2. Enable the students to realize the feelings of } \\
\text { different materials, and their effects on vision } \\
\text { and tangibility. } \\
\text { 3. Introduce the character and different kinds } \\
\text { of Chinese painting. } \\
\text { 4. Introduce the works from different periods, } \\
\text { different main artists, and their relationships } \\
\text { with contemporary background(Mainly focus } \\
\text { on Modern period, the Chin Dynasty, and the } \\
\text { Min Dynasty). } \\
\text { 5. Introduce the art works and the main artists } \\
\text { of the post-impressionist school of fine art. } \\
\text { 6. Introduce the works of the main Western } \\
\text { fine arts schools, and their relationships with } \\
\text { their contemporary background (After 20th } \\
\text { century). }\end{array}$ & 8 & \\
\hline
\end{tabular}

*(Ministry of Education, 1983, p. 168) 
Table 4

The Outline of Teaching Content: Third Grade*

\begin{tabular}{|l|l|l|l|}
\hline Categories & $\begin{array}{l}\text { Teaching } \\
\text { Content }\end{array}$ & Main Themes for Guidance & $\begin{array}{l}\text { Teach- } \\
\text { ing } \\
\text { Hours }\end{array}$ \\
\hline $\begin{array}{l}\text { Chinese } \\
\text { Painting }\end{array}$ & $\begin{array}{l}\text { Landscape } \\
\text { Painting } \\
\text { 2. Figure } \\
\text { Painting }\end{array}$ & $\begin{array}{l}\text { 1. Recognize and practice the Chinese painting } \\
\text { techniques by drawing trees and stones. } \\
\text { Furthermore, combine them as a landscape } \\
\text { painting. } \\
\text { 2. Take park or suburb views, apply subjective } \\
\text { artistic conceptions to create a landscape } \\
\text { painting. }\end{array}$ & 6 \\
$\begin{array}{l}\text { 3. Observe modern person or an actor's } \\
\text { dressing and appearances to represent the } \\
\text { significance and delight of the painting. }\end{array}$ & $\begin{array}{l}\text { 1 Introduce the appreciation of several } \\
\text { comfortable and beautiful interior designs. } \\
\text { 2. Introduce the applications of brush, ink, } \\
\text { color, title writing, chop application, mount, } \\
\text { and preservations of Chinese painting. } \\
\text { 3. Introduce the works from different periods, } \\
\text { different main artists, and their relationships } \\
\text { with their contemporary background (Mainly } \\
\text { focus on the Yen Dynasty, the Song Dynasty, } \\
\text { and the Tang Dynasty). } \\
\text { 4. Introduce the art works and the main artists } \\
\text { of the pre-impressionist school. } \\
\text { 5. Introduce the works of western fine arts, } \\
\text { and the relationships with contemporary } \\
\text { background } \\
\text { (Before 20th Century.) }\end{array}$ & 10 \\
\hline
\end{tabular}

*(Ministry of Education, 1983, p. 170)

The teaching principles for Chinese painting (Ministry of Education, 1983) were that the selection of teaching materials should be according to the students' physical and 
mental development as well as the needs of the age and locality, and match with other teaching subjects and activities in order to cultivate students' confidence and interests in fine art works. The teaching materials for appreciation classes should be prepared in advance, including lantern slides as well as the duplicates of Chinese and Western famous paintings, in order to evoke the students' interest through the representations of the visual and audio equipment, such as a slide projector or magic lantern.

The teaching evaluations for learning Chinese painting include the scope and content for evaluation of the representing works; it's representing works occupy $50 \%$ of the grade; knowledge of fine art occupies $30 \%$ of the grade, and learning attitude occupies $20 \%$ of the grade.

Evaluation Methods for Chinese painting include three points. First, the representing works are evaluated by dividing works into several degrees, comparing the same degree works, and so on. Second, knowledge of fine arts are evaluated by question answering, discussions, appreciation during the teaching, and by tests and questionnaires after the teaching. Third, the learning attitudes are evaluated by observing the students' reaction and recording them anytime before the teaching, during the teaching, and after teaching (Ministry of Education, 1983, pp. 175-176).

\section{Summary}

Art education is aimed at cultivating and promoting students' ability in art appreciation. It is regretful that in the past art creation was too much emphasized to 
the neglect of the advantages and value of art appreciation. Art education is a part of regular education which should not focus on the cultivation of artists. Because only few students will choose being an artist as a career there are a large number who are interested in better understanding and appreciation of art culture. Therefore, to enforce the ability of art appreciation not only meets the requirement of the education standards for the majority of people, but satisfies the need for social development.

Art education at junior high schools in Taiwan include Chinese painting, water painting, sketching, panel drawing, designing, sculpture designing and three-dimension designing as well as appreciation. The teaching materials are many, and the teaching methods match the various content. Since art education is so comprehensive the researcher prefers "Chinese painting" as a theme of instruction within art education.

Chinese Painting is one of the traditional art forms. It can be traced from ancient Chinese society. To specify the theme of the content of their work, an artist might choose people, landscapes, animals, flowers, fruits, feathers, animals and insects or fish. The skills, taught are "GongBi" and "XieYi". The former includes coloring and dotting the flowers or leaves; the latter includes MoGu which means stemless, and PoMo or ink-dipping.

The research does not cover Chinese Calligraphy due to time constraints, and instruments are unavailable. Therefore, this research includes the "MoGu" skill for painting fruits over eight weeks as a vehicle to promote art appreciation, cognition of students, painting skills and learning attitudes (Chen, 1989, pp. 3-13). 


\section{CHAPTER THREE}

\section{METHODOLOGY}

This chapter describes the sampling method used to select subjects for this study, the research design, the research procedures, and the data analysis procedures.

\section{The Subjects}

For this experiment, the subjects were junior high school students. In order to obtain a representative sample of Taiwan junior high school students, the northern part, southern, and eastern part of Taiwan were stratified. Because of the significant differences among schools, the researcher did not include those schools whose student populations were small in number or those that were reluctant to participate in the experiment. In order to acquire regional representation, three schools were randomly selected for the experiment, one school from each region. The three schools selected were as follows: from the northern part of Taiwan, Taipei Jin-Hwa Junior High school, from the southern part, Min-Yi Junior High School, and from the eastern part, Don-Hai Junior High School.

A total of 254 students, made up of six classes, were included in the study. The sample was selected to represent the school samples in Taiwan, and included Taipei Jin-Hwa Junior High School in Northern Taiwan, Kaohsiung Min-Yi Junior High School in Southern Taiwan, and Taidon Don-Hai Junior High School in Eastern 
Taiwan. These three schools randomly placed students into classes. The researcher randomly selected two classes from each school with one class assigned as the experimental group and the other as the control group. The experimental group received art appreciation education, while the control group received technical art creativity education. The distribution of students was as follows:

Taidon Don-Hai Junior High School (School E) consisted of thirteen (13) seventh grade classes. Taipei Jin-Hwa Junior High School (School K) and Kaohsiung Min-Yi Junior High School (School M) each had thirty-six (36) and sixteen (16) seventh grade classes respectively. One experimental and one control group was randomly selected from each school site (see Table 5).

Table 5

Students' Distribution of Each Group

\begin{tabular}{|l|l|l|l|}
\hline & School E & School K & School M \\
\hline Experimental & 1 & 1 & 1 \\
\hline Control & 1 & 1 & 1 \\
\hline Other & 11 & 34 & 14 \\
\hline Total & 13 & 36 & 16 \\
\hline
\end{tabular}

The gender composition for experimental and control groups from each school $(\mathrm{E}, \mathrm{K}$, and $\mathrm{M})$ are depicted in Table 6. As shown, each group consisted of a relatively equal balance by gender. In addition, class sizes were approximately 
comparable for both experimental and control groups for each school. In school E, experimental and control groups each consisted of forty-five $(n=45)$ subjects. School K had forty $(n=40)$ in the control group and thirty-nine $(n=39)$ in the experimental group. The experimental and control group for school $M$ had forty-one $(n=41)$ and forty-two $(n=42)$, respectively. Finally, all students were junior high seventh grade students, aged 13 to 14 , who did not have prior instruction in Chinese Painting.

Table 6

Analysis of Number of Students

\begin{tabular}{|l|l|l|l|l|l|l|l|}
\hline School & \multicolumn{4}{|l}{ Experimental } & \multicolumn{2}{l|}{ Control } & Total \\
\hline & $\begin{array}{l}\text { Male } \\
\%\end{array}$ & $\begin{array}{l}\text { Female } \\
\%\end{array}$ & $\begin{array}{l}\text { Subtotal } \\
\%\end{array}$ & $\begin{array}{l}\text { Male } \\
\%\end{array}$ & $\begin{array}{l}\text { Female } \\
\%\end{array}$ & $\begin{array}{l}\text { Subtotal } \\
\%\end{array}$ & \\
\hline E & 23 & 22 & 45 & 25 & 20 & 45 & 90 \\
& $26 \%$ & $24 \%$ & $50 \%$ & $28 \%$ & $22 \%$ & $50 \%$ & \\
\hline K & 19 & 20 & 39 & 20 & 20 & 40 & 79 \\
& $24.1 \%$ & $25.3 \%$ & $49.4 \%$ & $25.3 \%$ & $25.3 \%$ & $50.6 \%$ & \\
\hline M & 20 & 22 & 42 & 20 & 21 & 41 & 83 \\
& $24.1 \%$ & $26.5 \%$ & $50.6 \%$ & $24.1 \%$ & $25.3 \%$ & $49.4 \%$ & \\
\hline Total & 62 & 64 & 126 & 65 & 61 & 126 & 252 \\
& $24.6 \%$ & $25.4 \%$ & $50 \%$ & $25.8 \%$ & $24.2 \%$ & $50 \%$ & $100 \%$ \\
\hline
\end{tabular}

The study involved a total of 127 males (50.4\%) and 125 females (49.6\%). The experimental group represented $50 \%$ of the population while the control group the other $50 \%$. 


\section{Instrumentation and Data Collection}

\section{Evaluations of Art Work}

The study utilized a pretest-posttest non-equivalent control group design on creativity in traditional Chinese Painting. The pretest of student art work was administered before instruction implementation. Posttests of students' art work, knowledge and attitude toward art were administered at the end of the semester. Students completed examples of art work using the ancient Chinese techniques both prior to art instruction and at the end of the term. These works were evaluated by three art experts after the completion of the instructional aspect of the study. This was a special characteristic of this study. The pretest and posttest of combined art works (pretest and posttests) were reviewed at the same time by the experts in order to control for reviewer bias, therefore, there was no influence on grade by the reviewer for the novice student. The experts were professional artists, two were also art instructors. Each of the artists were recognized evaluators for fine art exhibitions (See Appendix E for Biographical Summaries).

A rating of "Excellent," "Good," "Fair," and "Poor" was used to grade the works by the experts. In order to maintain the integrity of the review, the researcher presented both the pretest works and the posttest works together to the expert raters in a meeting room at National Taiwan Normal University (NTNU). The three invited experts evaluated each piece of student art work according to established scales of 
Excellent, Good, Fair or Poor. The rank was marked on each work and recorded by the researcher as Excellent $=\mathrm{A}$, Good $=\mathrm{B}$, Fair $=\mathrm{C}$, and Poor $=\mathrm{D}($ See Appendix F).

\section{Cognitive Test}

The content of the questions for the cognitive test were extracted and edited from the Chinese painting part of the Junior High School Fine Art Textbook Verified by the Ministry of Education. This test included 20 questions. All the items were in the fill in the blank question format. The format was designed to avoid students' predications of the answers, and to increase the degree of accuracy in the aspects of art recognition.

Although reliability measures were not available, the test was accepted as possessing control validity for the Chinese Painting aspect of the curriculum. There is no standardized curriulum in Chinese Painting in Taiwan. The test was based on textbook content on Chinese Painting and was constructed by a professional artist and art professor.

\section{Learning Attitude Test}

The Learning Attitude Questionnaire (Lai, 1993) is a widely applied measurement for learning attitude in Taiwan. The questionnaire has both validity and reliability measures (Lai, 1993). In a survey of seventh grade students at Gia-Yi Junior High School, Gia-Yi Country, Taiwan, the split-half reliability coefficient on the eight 
items was 0.52 to 0.88 . For the purposes of this study, the questionnaire was accepted as reliable.

Questionnaire validity according to Gay (1996) points out:

That content validity is determined by expert judgment. There is no formula by which it can be computed and there is no way to express it quantitatively. Usually experts in the area covered by the test are asked to assess its content validity. These experts carefully review the process used in developing the test as well as the test itself and make a judgment concerning how well items represent the intended content area (Gay, 1996, p.140). The validity of the Learning Attitude Test was established through expert development utilizing theoretical foundations in the establishment of the eight areas and therefore is considered to possess content validity.

The Test of Learning Attitude is based on the Learning Psychological Principles, the teaching situations in Taiwan schools, the students learning situations, and the test preparation methods. This test emphasizes both theory and practice. Learning attitudes are divided into eight items: Learning Method, Learning Plan, Learning Habit, Learning Environment, Learning Desires, Learning Process, Preparation for Examination, and Techniques for Examination. There are three purposes for using this test. The first purpose is to improve the students' studying 
habits. The second purpose is to diagnose the causes for learning problems, and the third is to assist students to cultivate a good learning attitude (Lai, 1993, p. 3).

According to Lai (1993), learning attitudes are divided into eight items. This test is classified into eight items, each is composed of ten subitems of questions, for a total of eighty subitems. The content of each item on the test is listed as follows:

(1) Learning Method: Knowing whether the learning method meets the theories of psychology or not. Is time used effectively and efficiently? and so on.

(2) Learning Plan: Knowing whether students learn on a schedule.

Will they make a learning schedule at the beginning of every semester? and so on.

(3) Learning Habit: Knowing their study habits. Do they study while they are eating or do they lie on their bed? Do they scribble their exercise book? Do they prepare learning tools sufficiently? and so on. (4) Learning Environment: Knowing the advantage or dis advantage of place for learning. If the learning environment is quiet? and so on.

(5) Learning Desire: Knowing whether learning desire is strong or weak. Is their learning interest strong or weak? Do students do other homework besides teacher's assignment? and so on.

(6) Learning Process: Knowing the attentiveness of students in the class.

Do they take note or underline the paragraphs? and so on. 
(7) Prepare for Examination: Knowing whether they sufficiently prepare before the test. Is their way of preparing proper? and so on.

(8) Technique for Examination: Knowing students' psychological condition during and after the test. Are they able to fully show their abilities in the test or do they become nervous? Do they answer the easier questions first then the difficult ones? Are failures and successes on the test analyzed to remodel methods for the future (Lai, 1993, pp. 1-2)? In this study the students in both experimental and control groups filled out the questionnaire one week before classes ended.

\section{Procedures}

The researcher first randomly assigned treatments to the experimental and control groups. This process resulted in one experimental and one control group in each of the three schools participating in the study. The experimental group received the traditional art appreciation education of Chinese painting instructional strategy, while the control group received traditional Chinese painting and technical creativity education strategy. The teaching content was entirely based on the Junior High School Fine Art Textbook currently in use in Taiwan. The teaching material for Chinese painting and appreciation was also compiled from the textbook. In order to reduce the disruption of the school teaching environments, the researcher took intact classes as a 
unit for both experimental and control groups and adopted the non-equivalent-control group design (Guo, 1986). The experimental model is illustrated in Figure 2. Through this design, the researcher investigated influences of art appreciation education on creativity in traditional Chinese painting of Junior High School Students.

\begin{tabular}{|l|l|l|l|}
\hline & & Experimental & Control \\
\hline & & 3 classes & 3 classes \\
\hline Art Works & Pretest & $\mathrm{X}$ & $\mathrm{X}$ \\
\hline & Posttest & $\mathrm{X}$ & $\mathrm{X}$ \\
\hline Knowledge & Posttest & $\mathrm{X}$ & $\mathrm{X}$ \\
\hline Emotion & Posttest & $\mathrm{X}$ & $\mathrm{X}$ \\
\hline
\end{tabular}

Figure 2. Designed Experimental Model

Through the model, the researcher studied the effects of both appreciation instruction and traditional creation techniques on the work, knowledge, and students' attitude toward art. Posttest only information was collected for both learning attitude and for cognitive (knowledge) understanding. 


\section{Experimental Procedures}

The procedures for both experimental group and control group were divided into several stages: preparation stage, administrative coordination and pre-learning test stage, experimental process, and the post-learning test stage.

\section{Preparation Stages}

Since the research theme was The Effects of Chinese Painting Appreciation Education on the Artistic Achievement of Junior High School Students According to Ancient Chinese Teachings in Taiwan, Republic of China, the researcher reviewed the literature related to the theoretical foundation of conducting research in the Junior High School setting. This review produced a knowledge base covering the effects of traditional Chinese painting education with junior high school students.

\section{Administrative Coordination and Pre-Learning Tests}

In January 1995, the researcher randomly selected one junior high school each from Northern Taiwan, Southern Taiwan, and Eastern Taiwan. The researcher also obtained permission from each school to implement the study. The study was conducted with the seventh grade classes of Taipei Jin-Hwa Junior High School, Kaohsiung Min-Yi Junior High School, Taidon Don-Hai Junior High School. The researcher discussed the details of the experiment with the fine art teachers and the manager of teaching administration of each school. It was decided to provide the 
treatment once every two weeks for two hours duration (arranged by the three schools). All the teaching material and students' painting tools and paper were supplied by the researcher.

The same pretest of art work was administered to the experimental and control groups in each school in March, 1995. The same posttest of art work, learning attitude test, and knowledge test were administered to both the experimental and control groups in each school in June, 1995 following the completion of the instruction phase.

\section{Experiment in Process}

The eight week experiment was conducted from March 6th, 1995 through June, 1995. The instruction was given in the original fine art program regularly scheduled classes for both the experimental and control groups.

The experimental groups' instruction was based on the researcher's art appreciation teaching content, while the control groups' instruction was based on technical creativity teaching content (See Figure 3). In order to minimize the experimental errors, the following principles were applied:

1. The teaching outlines and the items were the same. The researcher planned the instructional content and the items for the experimental group (See Appendix C) and the control groups (See Appendix A and B).

2. For conformity, the teaching schedules were the same for each group (See Figure 3).

3. The teaching hours were also the same for each group (see Figure 3). 
4. During instruction, teaching was performed by the researcher. All of the tools, materials, paper, etc, were newly supplied by the researcher. Therefore, the researcher bought new brush, ink, cotton paper, and related materials for every student to paint.

5. Formative evaluation was part of the instruction during weeks two through seven. Prior to the end of class, the researcher collected, displayed, and critiqued the student art work, reteaching the concepts for ten minutes.

6. Summative evaluation took place for all groups during week eight and included the posttest for art work knowledge and attitude.

\section{Post-Learning Tests}

The class for the experimental classes ended on June 17, 1996. The knowledge, attitude and art work posttest was completed during the week from June 11 th to 17 th (See Figure 3). Time requirements for the knowledge test was 30 minutes, the attitude test was 30 minutes, and the posttest work was 40 minutes. After the posttest, the researcher maintained records of the tests as shown in Appendix F. 


\begin{tabular}{|c|c|c|c|c|c|}
\hline & \multicolumn{3}{|c|}{ Groups } & \multirow{2}{*}{$\begin{array}{l}\text { Experimental } \\
\text { Group } \\
\text { Teaching Content }\end{array}$} & \multirow{2}{*}{$\begin{array}{l}\text { Control Group } \\
\text { Teaching Content }\end{array}$} \\
\hline & Week & Dates & $\begin{array}{l}\text { Time } \\
\text { (Min.) }\end{array}$ & & \\
\hline & 1 & $\begin{array}{l}\text { Mar. } \\
5-11\end{array}$ & & $\begin{array}{l}\text { Pre-learning } \\
\text { Tests of art work }\end{array}$ & $\begin{array}{l}\text { Pre-learning } \\
\text { Tests of art work }\end{array}$ \\
\hline Formative & 2 & $\begin{array}{l}\text { Mar. } \\
19-25\end{array}$ & 100 & Chinese Painting & Flowers and Birds \\
\hline \multirow[t]{5}{*}{ Evaluation } & 3 & $\begin{array}{l}\text { Apr. } \\
9-15\end{array}$ & 100 & form, set up, pen & Climbing plants \\
\hline & 4 & $\begin{array}{l}\text { Apr. } \\
16-22\end{array}$ & 100 & \multirow[t]{4}{*}{ stroke and color } & \multirow[t]{4}{*}{$\begin{array}{l}\text { fruits and } \\
\text { vegetables }\end{array}$} \\
\hline & 5 & $\begin{array}{l}\text { May 1- } \\
6\end{array}$ & 100 & & \\
\hline & 6 & $\begin{array}{l}\text { May } \\
15-20\end{array}$ & 100 & & \\
\hline & 7 & $\begin{array}{l}\text { May } \\
20- \\
\text { Jun. } 3\end{array}$ & 100 & & \\
\hline $\begin{array}{l}\text { Summative } \\
\text { Evaluation }\end{array}$ & 8 & $\begin{array}{l}\text { Jun. } \\
11-1\end{array}$ & 100 & $\begin{array}{l}\text { Post-learning tests: } \\
\text { Posttest of art } \\
\text { works, knowledge } \\
\text { and attitude. }\end{array}$ & $\begin{array}{l}\text { Post-learning tests: } \\
\text { Posttest of art } \\
\text { works, knowledge } \\
\text { and attitude. }\end{array}$ \\
\hline
\end{tabular}

Figure 3. The Teaching Schedules for Each Group

\section{Summary}

The study attempted to determine the effects of Chinese art appreciation education versus technical art creativity education on the art work of seventh grade students. In addition, measures of knowledge (cognitive) and Learning Attitude were 
generated for comparison. A pretest-posttest for nonequivalent groups design was utilized to test the primary hypothesis. A posttest only element was included for knowledge and learning attitudes. 


\section{CHAPTER FOUR}

\section{RESULTS}

\section{INTRODUCTION}

This study sought to investigate the following hypotheses:

1. There will be a significant difference in the art work (painting works) produced by Taiwan Junior High School students who received instruction in Chinese painting appreciation as compared with students who did not receive this instruction.

2. There will be no significant differences in art achievement(knowledge) between Taiwan Junior High school students who receive instruction in Chinese painting appreciation as compared with students who do not receive this instruction.

3. There will be no significant differences in the attitude toward art between Taiwan Junior High School students who receive instruction in Chinese painting appreciation as compared with students who do not receive this instruction.

To address the first research hypothesis a non-equivalent control group design was used. The students in the treatment and control groups were required to produce art work samples as pretests and posttests.

The pretest sample of students' art work was collected during the first class period. The difficulty of the pretest was according to student age and standards of curriculum established by the researcher who had twenty years experience. To grade the test, the researcher used a four-level-grading method: excellent, good, fair, and 
poor. The researcher marked the grade and hid it so that it would not influence the results of the posttest.

Pretest and posttest art work were used to determine the effect of Chinese art appreciation the artistic ability of the students.

\section{Results of the Pretest and Posttest of Student Art Work}

\section{Pretest Art Work Result}

Before instruction, all students in each group prepared a pretest sample of their art work. In order to control for potential rater bias, the pretest painting samples were graded by the evaluation committee at the same time as the posttest art work samples.

The pretest results show that the combined mean of the three control

groups (classes) was 1.3, and the standard deviation was 0.6 (See Table 7). The combined mean of the three experimental groups, however, was 1.1 , with a standard deviation of 0.3 . In order to test for statistical significance, a One-Way Analysis of Variance was performed on the results of the pretest sample of art work. This procedure was to determine if the groups were equivalent in their art ability at the beginning of the study. 
Table 7

Means and Standard Deviations -Pretest Art Work

\begin{tabular}{|l|l|l|l|}
\hline Label & Number & Mean & Std. Dev. \\
\hline Control & 126 & 1.3 & .6 \\
\hline School E & 45 & 1.2 & .5 \\
\hline School K & 40 & 1.3 & .8 \\
\hline School M & 41 & 1.4 & .6 \\
\hline Experimental & 126 & 1.1 & .3 \\
\hline School E & 45 & 1.1 & .3 \\
\hline School K & 39 & 1.2 & .4 \\
\hline School M & 42 & 1.1 & .3 \\
\hline
\end{tabular}

The one way analysis of variance results are shown in Table 8.

Table 8

One Way Analysis of Variance - Pretest Score

\begin{tabular}{|l|l|l|l|l|l|}
\hline \multicolumn{3}{|c|}{ Sum of } & Mean & F. \\
Source & D.F. & Squares & Squares & Ratio & $\begin{array}{l}\text { F. } \\
\text { Prob. }\end{array}$ \\
\hline $\begin{array}{l}\text { Between } \\
\text { Groups }\end{array}$ & 1 & 1.5 & 1.5 & 5.79 & .0169 \\
\hline $\begin{array}{l}\text { Within } \\
\text { Groups }\end{array}$ & 249 & 64.5 & .26 & & \\
\hline Total & 250 & 66.0 & & & \\
\hline
\end{tabular}

$p<.05$ 
The results of pretest sample of art work reveals that the groups are not equivalent to begin with, $\underline{F}(1,249)=5.79 \mathrm{p}<0.05$, comparison of the group means reveals that the control group had superior art work compared with students in the experimental group prior to the treatment.

\section{Posttest Art Work Result}

In order to address the research hypothesis one, There will be a significant difference in the art works (painting works) produced by Taiwan Junior High School students who receive instruction in Chinese painting appreciation as compared with students who do not receive this instruction, posttest samples of students' art work were examined. As for the posttest art work, the combined mean and standard deviations in the control groups, experimental groups, are displayed in Table 9.

Table 9 shows that the mean and the standard deviation are 1.8 and 0.61 , and the experimental group respectively are 1.9 and 0.57. Factorial Analysis of Covariance was used to test the first research hypothesis. This procedure was used because the results of the pretest revealed that the groups were significantly different in their art work quality before the study began. The students' pretest art work served as the covariate. 
Table 9

Means and Standard Deviations - Posttest Art Work

\begin{tabular}{|l|l|l|l|}
\hline Label & Number & Mean & Std. Dev. \\
\hline Entire Population & 252 & 1.8 & .61 \\
\hline Control & 126 & 1.8 & .64 \\
\hline School E & 45 & 1.6 & .81 \\
\hline School K & 40 & 1.9 & .44 \\
\hline School M & 41 & 1.8 & .56 \\
\hline Experimental & 126 & 1.9 & .57 \\
\hline School E & 45 & 1.7 & .63 \\
\hline School K & 39 & 2.2 & .60 \\
\hline School M & 42 & 1.9 & .33 \\
\hline
\end{tabular}

The Factorial Analysis of Covariance (ANCOVA) performed on the posttest quality of art work results are displayed in Table 10. As shown, there is a significant main effect difference by group, $\underline{\mathrm{F}}(1,249)=5.67, \mathrm{p}<.05$, and by school, $\underline{\mathrm{F}}(2,249)$ $=8.75, \mathrm{p}<.05$. There was no significant interaction effect of group by school $(\underline{F}$ $(2.249)=.58, \mathrm{p}>.05)$. Therefore, the first null hypothesis was rejected, the experimental groups had significantly better quality of posttest art work compared with that of the control group. Comparison of the posttest means, adjusted for pretest scores as a covariate, reveal that the experimental group did not differ significantly between art work on the posttest compared with the control group. 
Table 10

Factorial Analysis of Covariance- Quality of Art Work Posttest

\begin{tabular}{|l|l|l|l|l|l|}
\hline $\begin{array}{l}\text { Source of } \\
\text { Variation }\end{array}$ & SS & DF & MS & F & Sig of F \\
\hline $\begin{array}{l}\text { Within }+ \\
\text { Residual }\end{array}$ & 83.5 & 243 & .3 & & \\
\hline $\begin{array}{l}\text { Pretest } \\
\text { Covariate }\end{array}$ & .4 & 1 & .4 & 1.05 & .306 \\
\hline Group & 2.0 & 1 & 2.0 & 5.67 & .018 \\
\hline School & 6.0 & 2 & 3.0 & 8.75 & .000 \\
\hline $\begin{array}{l}\text { Group by } \\
\text { School }\end{array}$ & .4 & 2 & .2 & .58 & .560 \\
\hline (Model) & 8.8 & 6 & 1.5 & 4.25 & .000 \\
\hline (Total) & 92.3 & 249 & .4 & & \\
\hline
\end{tabular}

$\mathrm{p}<.05$

In order to examine the main effects by schools, the researcher performed

Tukey's HSD Multiple Comparison Test (See Table 11). Based upon the results of a Tukey HSD post hoc comparison, the only significant difference between schools was found with school $\mathrm{K}$ versus school E. As reflected above, the students in School K had significantly high quality art work compared with those students enrolled in school E. 
Table 11

Results of Post Hoc Multiple Comparisons Test on Quality of Art Work Posttest By

School

\begin{tabular}{|l|l|l|l|}
\hline Comparison & Mean Difference & Std. Error & Sign \\
\hline School E vs. K & .39 & .091 & $.000^{*}$ \\
\hline School E vs. M & .20 & .090 & .074 \\
\hline School K vs. M & .20 & .093 & .088 \\
\hline
\end{tabular}

$* \mathrm{p}<.05$

Knowledge Achievement

The second research hypothesis examined in this study was: There will be significant differences in art achievement (knowledge) between Taiwan Junior High School students who receive instruction in Chinese painting appreciation as compared with students who do not receive this instruction. The researcher tested the students' knowledge of art with an art achievement posttest at the end of the study. For knowledge achievement, the means and standard deviations obtained from the control groups and experimental groups by school are shown in Table 12. As shown in Table 12, the combined control group and experimental group mean are 32.3 and 32.4 , respectively, and the standard deviations are 18.8 and 15.4 , respectively. 
Table 12

Means and Standard Deviations of Tests of Knowledge by Group

\begin{tabular}{|l|l|l|l|}
\hline Label & Number & Mean & Std. Dev. \\
\hline Entire Population & 252 & 32.4 & 17.2 \\
\hline Control & 126 & 32.3 & 18.8 \\
\hline School E & 45 & 22.6 & 18.8 \\
\hline School K & 40 & 47.0 & 21.0 \\
\hline School M & 41 & 27.9 & 12.9 \\
\hline Experimental & 126 & 32.4 & 15.4 \\
\hline School E & 45 & 32.5 & 16.5 \\
\hline School K & 39 & 36.6 & 14.7 \\
\hline School M & 42 & 28.3 & 14.0 \\
\hline
\end{tabular}

The results of a Factorial Analysis of Variance, results are shown in Table 13.

After the test, it was found that there were no significant differences in terms of knowledge achievement between the two groups $(\underline{F}(1.243=0.00, p>0.05)$. But there were significant differences in terms of knowledge achievement between the three schools $(\underline{F}(2,243)=21.83, \mathrm{p}<0.01)$. Moreover, the results of the Factorial Analysis of Variance reveals a significant Group by School interaction effect, $\underline{F}(2,243)$ $=8.84, \mathrm{p}<.01$. 
Table 13

Analysis of Variance Tests of Significance for Knowledge Using Unique Sums of

$\underline{\text { Squares }}$

\begin{tabular}{|l|l|l|l|l|l|}
\hline $\begin{array}{l}\text { Source of } \\
\text { Variation }\end{array}$ & SS & DF & MS & F & Sig of F \\
\hline $\begin{array}{l}\text { Within }+ \\
\text { Residual }\end{array}$ & 56851.3 & 238 & 238.8 & & \\
\hline Group & .05 & 1 & .05 & .00 & .988 \\
\hline School & 10426.8 & 2 & 5213.4 & 21.83 & $.000^{*}$ \\
\hline $\begin{array}{l}\text { Group by } \\
\text { School }\end{array}$ & 422.4 & 2 & 211.2 & 8.84 & $.000^{*}$ \\
\hline (Model) & 14768.4 & 5 & 2953.7 & 12.37 & .000 \\
\hline (Total) & 71619.7 & 243 & 294.7 & & \\
\hline
\end{tabular}

$* \mathrm{p}<.005$

The graph of the means (See Figure 4) reveals a significant disordinal interaction effect. As shown, the experimental group outperformed the experimental group in School E and School M, while the control group outperformed the control group in School K. Therefore, the second null hypothesis was rejected. 
Treatment: Control Experimental

Figure 4. Interaction effect on Student Knowledge Group by School

Attitude

The third research hypothesis addressed in this study was: There will be no significant differences in the attitude towards art between Taiwan Junior High School students who receive instruction in Chinese painting appreciation as compared with students who do not receive this instruction.

The main purpose of this section was to analyze the major difference in the attitude of the experimental group and control group after the treatment. The Learning Attitude Questionnaire resulted in categories for "Appreciation," "Fine Art Interest," and "Learning Procedures." The results are summarized in Table 14. 
Table 14

Means and Standard Deviations - Students' Attitude

\begin{tabular}{|l|l|l|l|}
\hline Label & Number & Mean & Std. Dev. \\
\hline Entire Population & 252 & 54.7 & 18.8 \\
\hline Control & 126 & 56.4 & 19.1 \\
\hline School E & 45 & 52.4 & 21.5 \\
\hline School K & 40 & 64.3 & 18.4 \\
\hline School M & 41 & 53.0 & 14.4 \\
\hline Experimental & 126 & 53.0 & 18.4 \\
\hline School E & 45 & 48.0 & 18.8 \\
\hline School K & 39 & 49.6 & 17.2 \\
\hline School M & 42 & 61.8 & 16.2 \\
\hline
\end{tabular}

As shown on the Table 14, the combined means of the control groups and experimental groups are 56.4 and 53.0, respectively, the standard deviations are 19.1 and 18.4 , respectively. In order to test the null hypothesis, the researcher performed a Factorial Analysis of Covariance. The results of the analysis are shown in Table 15. 
Table 15

Analysis of Variance of Students' Attitude Toward Art

\begin{tabular}{|l|l|l|l|l|l|}
\hline $\begin{array}{l}\text { Source of } \\
\text { Variation }\end{array}$ & SS & DF & MS & F & Sig of F \\
\hline $\begin{array}{l}\text { Within }+ \\
\text { Residual }\end{array}$ & 79245.5 & 246 & 322.2 & & \\
\hline Group & 744.1 & 1 & 744.1 & 2.31 & .130 \\
\hline School & 2812.4 & 2 & 1406.2 & 4.36 & $.014^{*}$ \\
\hline $\begin{array}{l}\text { Group by } \\
\text { School }\end{array}$ & 5652.1 & 2 & 2826.0 & 8.77 & $.000^{* *}$ \\
\hline (Model) & 9157.2 & 5 & 1831.5 & 5.68 & .000 \\
\hline (Total) & 88411.9 & 251 & 352.2 & & \\
\hline
\end{tabular}

$* \mathrm{p}<.05 \quad * * \mathrm{p}<.01$

It was found that there was no significant differences in terms of attitude toward art between the two groups $\underline{F}(1,251)=2.31, \mathfrak{p}>0.05$. There is, however, a significant difference in the students' attitude by schools $\underline{\mathrm{F}}(2,251)=4.36, \underline{p}<0.05$. Furthermore, the results of the Factorial Analysis of Variance reveals a significant Group by School interaction effect, $\underline{F}(2,251)=8.77, \mathfrak{p}<.01$. The graph of the means (See Figure 5) reveals significant disordinal interaction. The control group demonstrated a higher attitude for art than the experimental group in both school E and school K. For school M, the experimental group had a higher attitude for art than the control group. Therefore, the null hypothesis was rejected. 
60

50

40

School E

Treatment:
School K

Control
School M

Figure 5. Interaction Effect-Attitude Group by School

\section{Summary}

The results of the pretest of art work show a significant difference between the control group and experimental group with the control group having a higher score prior to treatment. The results of posttest of art work, controlling for the initial pretest differences, show a significant difference between the control group and the experimental groups. Additionally, the results of the knowledge achievement shows that there was a significant school by treatment interaction effect. Finally, the result of the attitude tests also revelas a significant treatment by school interaction effect.

Results of the three posttests (in art work, knowledge achievement, and attitude), are depicted in Table 16. 
Table 16

Results of Three Posttests

\begin{tabular}{|l|l|l|l|}
\hline & Group & Class & Group by Class \\
\hline In Art Work & Significant & Significant & Not Significant \\
\hline $\begin{array}{l}\text { Knowledge } \\
\text { Achievement }\end{array}$ & Not Significant & Significant & Significant \\
\hline Attitude & Not Significant & Significant & Significant \\
\hline
\end{tabular}

From the analysis of the above table, it was found that in art work there was a significant difference between the two groups, but knowledge achievement and attitude did not show a significant difference between the two groups. Further, there was a significant difference between the three classes for posttest art work. There was no significant difference in interaction with the group and class, but knowledge achievement and attitude resulted in a significant difference in interaction with the group and class. 


\section{CHAPTER FIVE \\ CONCLUSIONS AND RECOMMENDATIONS \\ INTRODUCTION}

The purpose of this study was to determine the effects of Chinese Painting Appreciation on the artistic achievement of Junior High School students in Taiwan. The following hypotheses were the focus of the study:

1. There will be a significant difference in the art work (painting works) produced by Taiwan Junior High school students who receive instruction in Chinese painting appreciation as compared with students who do not receive this instruction.

2. There will be significant differences in art achievement (knowledge) between Taiwan Junior High school students who receive instruction in Chinese painting appreciation as compared with students who do not receive this instruction.

3. There will be significant differences in the attitude toward art between Taiwan Junior High School students who receive instruction in Chinese painting appreciation as compared with students who do not receive this instruction.

The researcher has taught Chinese Painting more than twenty-five years, and found that art education advocates the importance of art appreciation education. In Junior High school, art is a required course. Chinese painting emphasizes Chinese art and culture.

In this study, the researcher chose two different teaching methods to teach in Junior High School's in Taiwan. The research design for this study was a non- 
equivalent control group design. The experimental group method was to use art appreciation instruction to teach, and the control group method used traditional instruction.

The psychological aspect and the aesthetic aspect approach to Chinese painting teaching used the famous painting theory of the six methods of Hsieh Ho. Chinese painting was taught in each class at each Junior High School in the sample. An experimental two group design was used in this study. The experimental group was taught by art appreciation instruction, and the control group was taught by traditional instruction. Students had a pretest and a posttest in art work, but only a posttest in knowledge achievement and attitude.

The case study took two sample classes from Jin-Hwa junior High School in Taipei, Taiwan with 79 students, two classes from Ming-Yi Junior High School in Kaohsiung with 83 persons, and another two classes from Don-Hai Junior High School with 90 persons. A total of 252 students were in the experiment. They were taught Chinese Art Appreciation including designing, setting up, exertion of brushes, coloring and so on.

After teaching, a four-level-grading method was used to evaluate the students' art work. Statistical analysis was used to test the data obtained by the Learning Attitude Questionnaire and the knowledge test. 
The results of analysis found the following:

(1). The pretest and posttest of art work showed a significant difference between the two groups. The combined means of the pretest and the posttest for each group was as follows (Table 17):

Table 17

The Combined Mean of Two Tests of Each Group

\begin{tabular}{|l|l|l|}
\hline Group & Pretest & Posttest \\
\hline Experimental Group & 1.1 & 1.9 \\
\hline Control Group & 1.3 & 1.8 \\
\hline
\end{tabular}

Results show that not only both groups benefitted from in the teaching effect, but the experimental group profited more than the control group from the teaching. The net increase for the experimental group was .8 as compared to .5 for the control group, indicating greater growth in art work scores.

(2). The posttest of knowledge achievement showed that there were no significant differences between the two groups, but a significant difference existed between the three schools. The reasons for this are:

A. Drawing is not a required course for the entrance examination, parents and students do not value it, also most students do not learn it without great effort, therefore the scores are very low. 
B. The content of the mid-term and final is designed according to the standardized text book certified by the Ministry of Education. Therefore, students are able to handle only certain levels of textbook work regardless of the nature of the class.

C. Among the six classes, the score of control School K was the highest. It was later discovered that the academic adviser of the class was more rigid and his expectations were higher for the students.

In the experimental group and control group, the score of School K (northern target) was higher than that of any other school, because the academic environments and culture standard of Taipei are higher than those of any other city in Taiwan. Perhaps it was that the high expectations of the students influenced their performance in knowledge achievement.

(3). The posttest of attitude showed that there were no significant differences between the two groups, but there was a significant difference between the three classes. The reasons are as follows:

A. Students learn with a highly curious attitude because they never had contact with ancient Chinese painting before. They learned because of this novelty effect, without any in-depth probe instruction necessary.

B. In the process of instruction, the instructor provided tools and materials for students; in addition, the instructor is a professor with expertise at the university level, therefore every student tried harder to learn and felt motivated by having a university teacher. 
The control group students emphasized more of the analysis of color and lines of particular items, while the experimental group students paid more attention to the whole picture's atmosphere, thus the performance of the experimental group was better than the control group in the aspect of fine art interest.

During each class, the experimental group of students concentrated more, were more willing to express their opinions, and were more relaxed and in a learning mood. On the other hand, the control group students tended to emphasize repetitive practice of drawing lines, which caused more stress and fear of being unable to copy exactly. More emphasis was placed on drawing than teaching. The experimental group's interest was greater than the control group.

In the control group, several students tended to tease one another for their inability to imitate lines properly, thus the learning atmosphere was not very encouraging. On the other hand, the experimental group students were more understanding of each other's works and tended to encourage each other, thus the learning atmosphere was more harmonious. Learning procedures in the experimental group, therefore, were better than in the control group.

\section{Conclusion}

The conclusions of this study are as follows:

(1) Chinese Art Appreciation instruction has positive and significant influences on students' creativity ranging from completing the painting, creative thinking, tactful 
exertion of brushes, designing the arrangement and flexibility in usages as shown in both statistics and in products. Furthermore, with respect to the research, students are influenced in a profitable and positive way in Chinese Painting creative ability through Art Appreciation courses.

(2) In evaluating standards of art creative capability, the research adopted the conclusive evaluative methods to evaluate students' art creativity. Five criteria proposed in the study were: a. The level of completion of the painting. b. Creative thinking or expression in painting. c. Exertion of brushes. d. Designing and arrangement of the settings. e. Color arrangement expression. The evaluator judged and gave scores according to each item. (3) From the experiment, it was apparent students made progress in creativity and art appreciation because of the teaching method of Art Appreciation Teaching. Therefore, art appreciation teaching curriculum is suitable and positive for junior high school students' art creation activities.

\section{Recommendations for Further Study}

The results of this research conclude that as long as students receive well-organized Art Appreciation Courses, they will have great promotion of their creative abilities. As a consequence, teachers should change the way they teach and use Art Appreciation teaching methods. First of all teachers should give the students a complete background of knowledge (including Art History, Art Criticism, and basic knowledge of Art), then encourage students to try to create and paint by themselves. 
Teachers need to supervise and observe whether or not students use what they learned, how many use the techniques, and how they apply their imagination in their works appropriately. Next, teachers should leave opportunities for students to talk about their own creative motivation, ideas, and thoughts and stage analytic discussions about their own work.

Evaluation is rather important in the process, but most art teachers grade art works depending on the entire expression rather than evaluate element by element. Therefore there is no precise way for students to understand thoroughly their own ability in art creativity. The proposed itemized evaluation would meet this requirement and solve the problem while helping the students better understand their own art creativity. With such positive interaction between teachers and students, teachers will improve teaching efficiency.

It is recommended that a standard evaluation design for the artistic creativity of junior high school students be developed. This should be in accordance with the documentation and actual teaching requirement and will be an essential issue in the near future.

The research conducted was limited by time, and did not include subjects such as Chinese calligraphy, carving, sculpture and design, focusing on Chinese Art Appreciation Teaching. Beside Chinese Painting, these other subjects are different in structure and materials that have much appreciation value. The researcher suggests 
adjusting art appreciation teaching according to each of these other subjects. It is also regretful the cases for this research were limited due to practical reasons. Five classes were chosen at three junior high schools from three different areas in Taiwan:

Ging-Hua in Taipei, Ming-Yi in Kaohsiung, and Tong-Hai in Taitung so as to eliminate the limitation of variance of such factors as intelligence, emotions, teachers' concerns, art aptitude, living environments and cultural background.

Future research should focus on these limitations and how to practice Art Appreciation Teaching in not only junior high school students but at different levels. Further, research on creativity development at each age level and the experimental effects of teaching is needed.

The documentation referred to by the researcher in the evaluation tests is in compliance with the requirement of experimental teaching. It will take further efforts to prove if it is also suitable for different age level students' art works. There is no objective evaluation standards for art works. It becomes a crucial tendency to create an appropriate evaluation test for cognition and painting.

The research proved that Chinese Art Appreciation Teaching was positive and promoted junior high school students' abilities. In the future, research should focus on the following questions: Will other subjects help promote students' creative abilities? Will different age level students (ranging from elementary to college) receive benefits from Art Appreciation Courses? The suggestions from the researcher is to establish a 
well-organized art Appreciation Teaching Program for different age level students to prove that the influence of this program is profound and ever lasting. 


\section{REFERENCES}

Armheim, C. F. (1969). Visual thinking. Berkeley \& Los Angeles. CA: University of California Press.

Armheim, C. F. (1968). Art and visual perception. Berkeley \& Los Angeles. CA: Taipei: Ta-Lu Books.

Chao, H. L. (1989). Experiment and research on the effect of combined art history and art critic education method on the appreciative learning of Junior High School students. National Taiwan Normal University Art Research Institute Master of Arts Thesis.

Chen, C. F. (1988). Research of Chinese painting. Taipei City: Tan-Ching Library Publishing Co.

Chen, S. M. (1989). Evaluation of Junior High School art appreciation education evaluation and examples.

China Artistic Dictionary Compiler Committee. (1987). Chinese painting. p. 3.

Efland. A. D. (1979). Conceptions of teaching in art education. Art Education.

Eisner, E. W. (1983). On the relationship of conception to representation. Art Education 3 (2).

Eisner. E. W. (1981). Mind as cultural achievement. Educational Leadership. $38(6)$

Eisner. E. W. (1972). Educating artistic vision, NY: Collier Macmillan. Inc. 
Feldman. E. B. (1970). Becoming human through art. Englewood Cliffs. NJ Prentice-Hall. Inc.

Feng, T. K. (1988). Concepts of Chinese painting: Discussion about the six methods of painting by Yuan Hsing-Wu of Chin. Fu Wen Library Publishing Co., pp. 133-135.

Gay, L. R. (1996). Educational research, Competencies for analysis and application. Fifth Edition. Englewood Cliffs, NJ: Prentice-Hall, Inc.

Good, T. L. \& Brophy, J. E. (1990). Educational psychology. NY: Colliers. Guo, S. Y. (1986). The research of psychology and education. Taipei: ChingHua Books, Inc.

)

Hardiman, G. W. \& Zernich. T. (1981). Curriculum considerations for art education. In G. W. Hardiman \& T. Zernich (Eds). Foundations for curriculum development and evaluation in art education. Champaign, IL: Stipes Publishing Co.

Ho, W. F. (1985). Research on foundation of drawing appreciation education theory, Taipei: National Taiwan Normal University Art Research Institute. Master of Art thesis.

Huang. J. L. (1993). The appreciation of creative theory on children's art teaching. Proceedings for the 1993 International Symposium on Aesthetic Education. Ministry of Education.

Jean, C. F. \& Inhelder. P. B. (1967). The child's conception of space. NY: The Norton Library. 
Kuo, C. H. (1994). Secondaryart education. Taipei: Taiwan Normal University, the Secondary Education Committee.

Lai, P. C. (1993). The test of learning attiude Taipei: The Association of China Behavior Science. Chin-Chang Inc.

Lin, P. S. (1983). The research of creative on art education. Taipei: National Taiwan Normal University Art Research Institute, Master of Art thesis.

Liu, F. R. (1984). Research on Eisner's ars education concept. Taipei. Sui Niu Publishing.

Liu. W. T. (1987). Junior high school art. Books 1, 2. and 3. Instititue of Translation and Compilation. Taipei: Commercial Publishing.

Liu, W. T. (1984). Modern art Taipei: Commercial Publishing.

Ministry of Education (1995). Education statistics of the Republic of China.

Taipei: Jung-Min Publishing Co.

Ministry of Education (1983). The curriculum standarcis of Junior High School. Taipei City: Cheng Chung Books.

Read, H. (1956). Education through art. London: Faber.

Stolnitz. J. (1960). Aestherics and philosophy of art criticism, Boston:

Houghton Mifflin Company.

Wang, H. H. (1992): The research of art criticism appreciation teaching.

Proceedings for International Symposium on School Aesthetic Education. Ministry of Education. 
Wang. H. H. (1990). Fine art and education. Taipei City: Shen-shih Publishing Co. Lid.

Wang. H. H. (1975). The psychology of Junior High School students and an original work of art. Middle Education, 26 (2).

Wang. W. C. (1986). Art appreciation education theory and research: An analysis of the Junior High School art appreciation courses for the past 30 years. National Taiwan Normal University Art Research Institute Master of Arts thesis.

Wang. W. K. (1996). Educational research methods. Taipei: Wu-Nan Publishing Company.

Yang, J. K. (1990). Chinese painting and calligraphy. Shanghai: Shanghai Ku-Chi Publishing Co. Ltd.

Yu. C. H. (1987). The research of Chinese painting Taipei City: Hua-Cheng Books.

Yu. T. T. (1981). Chinese painting in four seasons. NJ: Prentice-Hall, Inc. 


\section{APPENDIX A:}

DESIGN LIST OF TEACHING ACTIVITIES

FOR TRADITIONAL PAINTING SKILLS:

FIRST SCHOOI, YEAR, CONTROL SECTION 
APPENDIX A; Design List of Teaching Activities for Traditional Chinese Painting Skills: First School Year, Control Section

\begin{tabular}{|c|c|}
\hline Name of Unit & The Interest in Pen and Ink \\
\hline Class & First school year of common class \\
\hline Number of Persons & Jing Hua 42 , Ming Yi 42 , Tong Hai 45 \\
\hline Source of Taught & Faine-art textbook of first school year junior high \\
\hline Materials & school \\
\hline Teacher & Chen. Hsiu-Hsiung \\
\hline Time & 100 minutes \\
\hline $\begin{array}{l}\text { Research on Taught } \\
\text { Materials }\end{array}$ & $\begin{array}{l}\text { 1. This unit is the Chinese Painting course the students of junior high } \\
\text { school first attend. The course applies methods to bring out the } \\
\text { students interest } \\
\text { 2. This unit emphasizes enabling the students to understand the } \\
\text { interest of pen and ink and also to use the real objects to practice } \\
\text { the changes of pen and ink. }\end{array}$ \\
\hline $\begin{array}{l}\text { Analysis of student } \\
\text { learning conditions }\end{array}$ & The students have not learned Chinese Painting before. \\
\hline Teaching Method & Combining instructions, demonstrations and analysis. \\
\hline Teaching Source & $\begin{array}{l}\text { (1) The pictures mainly emphasize the changes of "Line" and "Ink } \\
\text { Rhythm" in the Chinese Painting, reference books. and } \\
\text { demonstration books. } \\
\text { (2) Though Chinese Painting supplies such as pen, ink, paper, and } \\
\text { ink-stick the teacher and students will bring together, } \\
\text { newspapers, cloth cushion, dish cloth or tissue papers, textbook, } \\
\text { projector, projective films. }\end{array}$ \\
\hline
\end{tabular}




\begin{tabular}{|c|c|}
\hline \multicolumn{2}{|c|}{ Teaching Goal } \\
\hline Unit Goal & Substantial Goal \\
\hline (A) Knowledge Part & The students \\
\hline $\begin{array}{l}\text { 1. To understand the tools for Chinese } \\
\text { Paintings. }\end{array}$ & $\begin{array}{l}\text { 1. can understand the tools for Chinese } \\
\text { Painting. }\end{array}$ \\
\hline $\begin{array}{l}\text { 2. To understand the characteristics of } \\
\text { "Lines" and "Ink color" in Chinese }\end{array}$ & $\begin{array}{l}\text { 2-1. can understand the special features of } \\
\text { chinese painting. }\end{array}$ \\
\hline (B) Technical Part & $\begin{array}{l}\text { 2-2. can distinguish the delicate } \\
\text { arrangements and coordination of } \\
\text { "Lines" and "Ink" in the Chinese } \\
\text { Painting. }\end{array}$ \\
\hline $\begin{array}{l}\text { 3. To be familiar with the pen and ink } \\
\text { application. }\end{array}$ & $\begin{array}{l}\text { 3-1. can learn the correct way of holding the } \\
\text { pen. }\end{array}$ \\
\hline & $\begin{array}{l}\text { 3-2. can understand the changes of dry, wet, } \\
\text { thick and light lines and ink. }\end{array}$ \\
\hline $\begin{array}{l}\text { 4. To learn the observation and expressing } \\
\text { method. } \\
\text { (C) Emotion Part }\end{array}$ & $\begin{array}{l}\text { 4-1. can demonstrate how to observe. } \\
4-2 \text {. can demonstrate how to use water ink to }\end{array}$ \\
\hline $\begin{array}{l}\text { 5. To cultivate the interest in Chinese } \\
\text { Painting. }\end{array}$ & $\begin{array}{l}\text { 5. can demonstrate an appreciation the pen } \\
\text { meaning and ink interest in the Chinese } \\
\text { Paintings. }\end{array}$ \\
\hline $\begin{array}{l}\text { 6. To cultivate the students concern the } \\
\text { thing surrounding them and to show } \\
\text { their interests. }\end{array}$ & $\begin{array}{l}\text { 6. can find the beauty of the practical objects } \\
\text { in daily life. }\end{array}$ \\
\hline
\end{tabular}

\begin{tabular}{|c|c|l|}
\hline Class & Time & Highlights of teaching \\
\hline 1 & $50 \mathrm{~min}$. & $\begin{array}{l}\text { To introduce and appreciate the toots the changes of "Lines" } \\
\text { and "Ink color" in Chinese painting. }\end{array}$ \\
\hline 2 & $50 \mathrm{~min}$. & $\begin{array}{l}\text { The students start paint themselves and make appraisals of } \\
\text { their work. }\end{array}$ \\
\hline
\end{tabular}




\begin{tabular}{|c|c|c|c|c|}
\hline $\begin{array}{l}\text { Teaching } \\
\text { Goal }\end{array}$ & Teaching Activities & Teaching & Time & Appraisal \\
\hline $2-1$ & $\begin{array}{l}\text { 1. Preparatory Activities: } \\
\text { (1) The teacher prepares the } \\
\text { demonstrated picture mainly } \\
\text { with "lines" and "Ink color". } \\
\text { (2) The teacher prepares the } \\
\text { advantaged and disadvantaged } \\
\text { works from the students of the } \\
\text { same age. } \\
\text { (3) The teacher and students prepare } \\
\text { the painting supplies such as } \\
\text { pen, ink, paper, and ink-stick. } \\
\text { (4) The students bring one favorite } \\
\text { object. } \\
\text { 2. Developing Activities: } \\
\text { (1) To introduce what is Chinese } \\
\text { Painting and western painting } \\
\text { and compare thier differences. } \\
\text { period the Chinese painting ever } \\
\text { modem Chinese Painting. }\end{array}$ & & $10^{\prime}$ & $\begin{array}{l}\text { To be a ble to } \\
\text { prepare the listed } \\
\text { supplies and real } \\
\text { objects } \\
\text { To be able to know } \\
\text { and compare listed } \\
\text { supplies Chinese } \\
\text { painting and } \\
\text { western painting. }\end{array}$ \\
\hline
\end{tabular}




\begin{tabular}{|c|c|c|c|c|}
\hline $2-1$ & $\begin{array}{l}\text { (3) To introduce how a good Chinese } \\
\text { Painting should appear. }\end{array}$ & & & $\begin{array}{l}\text { will demonstrate the ability } \\
\text { to remember the qualities of } \\
\text { good Chinese painting. }\end{array}$ \\
\hline $2-2$ & $\begin{array}{l}\text { (4) To introduce different types of } \\
\text { performances of pen and ink. }\end{array}$ & pictures & & \\
\hline 5 & $\begin{array}{l}\text { (5) To appreciate various } \\
\text { demonstrated works. }\end{array}$ & works & $10^{\prime}$ & Remember \\
\hline 1 & $\begin{array}{l}\text { (6) To introduce Chinese Painting } \\
\text { supplies and its function and and } \\
\text { simple selections and maintenance } \\
\text { method. }\end{array}$ & $\begin{array}{l}\text { Chinese } \\
\text { Painting } \\
\text { supllies }\end{array}$ & $10^{\prime}$ & $\begin{array}{l}\text { To demonstrate knowlege of } \\
\text { suppies and this function }\end{array}$ \\
\hline 5 & $\begin{array}{l}\text { (7) To exhibit various water ink } \\
\text { demonstrated work of Chinese } \\
\text { Painting. }\end{array}$ & student work & & $\begin{array}{l}\text { student will be able to } \\
\text { compare and describe the } \\
\text { advantage and disadvantage } \\
\text { of their work. }\end{array}$ \\
\hline $3-1$ & $\begin{array}{l}\text { (8) To let students experience the } \\
\text { feeling of the pen drawing on the } \\
\text { paper and the variations of thick, } \\
\text { light, dry, and wet colors. }\end{array}$ & & $10^{\prime}$ & $\begin{array}{l}\text { The demonstrate abilities to } \\
\text { paint. }\end{array}$ \\
\hline $4-1$ & $\begin{array}{l}\text { (9) To discuss different qualities of } \\
\text { the still objects, which one shall be } \\
\text { thicker or lighter? Which one shall } \\
\text { be better for "line" performance and } \\
\text { which one shall be suitable for ink } \\
\text { variations? }\end{array}$ & & 51 & $\begin{array}{l}\text { To be able to understand and } \\
\text { to describe }\end{array}$ \\
\hline $4-2,6$ & $\begin{array}{l}\text { (10) To carefully observe the object, } \\
\text { itsshape, quality felling, bringht or } \\
\text { dark tone and consider its } \\
\text { performance method. }\end{array}$ & & $5^{\prime}$ & $\begin{array}{l}\text { To be able to observe and } \\
\text { judge }\end{array}$ \\
\hline $4-3$ & $\begin{array}{l}\text { (11) To guide the students to make a } \\
\text { draft drawing sketch. }\end{array}$ & & & To be draw a sketch. \\
\hline
\end{tabular}




\begin{tabular}{|c|c|c|c|c|}
\hline $4-2$ & $\begin{array}{l}\text { (12) To do Chinese Painting by } \\
\text { covering the painting paper on } \\
\text { manuscript. Using the above } \\
\text { experiance the students start to a paint } \\
\text { but only have todisplay a still object. } \\
\text { (13) The teacher must observe all the } \\
\text { students and give individual } \\
\text { instruction. } \\
\text { 3.Combined Activities: } \\
\text { (1) To exhibit the students' works fror } \\
\text { several separate teams and select one } \\
\text { or two excellent works from all class } \\
\text { works. }\end{array}$ & student work & $35^{\prime}$ & $\begin{array}{l}\text { To demonstrate the ability to } \\
\text { appreciate }\end{array}$ \\
\hline 5.6 & $\begin{array}{l}\text { (2) To exhibit the excellent works } \\
\text { selected from each team and let the } \\
\text { author deliver his/ her own remarks. } \\
\text { (3) The teacher and students discuss } \\
\text { what conditions the excellent works } \\
\text { shall have and give encouragement. } \\
5.6\end{array}$ & & $15^{\prime}$ & $\begin{array}{l}\text { To be able to express his/her } \\
\text { own remarks. } \\
\text { To show appreciation for } \\
\text { excellent works. } \\
\text { To be able to things from } \\
\text { beginning to the end, without } \\
\text { giving up halfway. }\end{array}$ \\
\hline
\end{tabular}




\begin{abstract}
!
APPENDIX B:

DESIGN LIST OF TEACHING ACTIVITIES

FOR TRADITIONAL CHINESE PAINTING:

FIRST SCHOOL YEAR, CONTROL SECTION
\end{abstract}


APPENDIX B: Design List of Teaching Acitivities for Traditional Chinese Painting: First School Year, Control Section

\begin{tabular}{|c|c|}
\hline Name of Unit & Flowers and Birds.....climbing plants fruits and vegetables \\
\hline Class & First School Year of common class \\
\hline $\begin{array}{l}\text { Nummber of } \\
\text { person }\end{array}$ & Jing Hua 42, Ming Yi 41 , Tong Hai 45 \\
\hline $\begin{array}{l}\text { Source of } \\
\text { Taught } \\
\text { Materials }\end{array}$ & Self-compilation \\
\hline Teacher & Chen. Hsiu-Hsiung \\
\hline Time & 600 minutes \\
\hline $\begin{array}{l}\text { Research on } \\
\text { Taught materials }\end{array}$ & $\begin{array}{l}\text { 1. In this unit, grapes, bottle-gourd, sponge-gourd, } \\
\text { pumpkin etc. climbing plants, fruits, and vegetables in the flowers and } \\
\text { birds were introduced. } \\
\text { 2. To enable the students through demonstrations and intructions to } \\
\text { understand how to create a flower and bird painting. }\end{array}$ \\
\hline $\begin{array}{l}\text { Analysis of } \\
\text { student learning } \\
\text { condition }\end{array}$ & To try the unit course for fun of pen and ink. \\
\hline $\begin{array}{l}\text { Teaching } \\
\text { method }\end{array}$ & Combining instructions, demonstrations and analysis. \\
\hline Teaching Source & $\begin{array}{l}\text { Textbook, related pictures, reference works, used papers or cloth cushion, } \\
\text { dish-cloth, tissue papers or a towel, projective film, projector, related } \\
\text { painting books, painting tools. }\end{array}$ \\
\hline
\end{tabular}


A. Knowlege Par:

1. To understand common knowlege of climbing plants fruits and vegetables.

2. To understand the basic concept of composition and layout.

3. To undersand the simple way of commentaries.

B. Technical Part

4. To imitate the demonstrated works or drawings on the pictures through the demonstrated skills of the teachers.

5. To create a flower and bird painting by inferring from what is already known.

6. To be able to select the best place for commentaries in order to enhance the pictures effect and reach the best composition.

C. Emotion Part

7. To cultivate the interest in Chinese Painting.

8. To cultivate, using the special features of the writing brush, in an order understanding of the special features of Chinese Painting.

9. To understand, appreciate, and to continue to create Chinese cultures.
Substantial Goal

1-1. The students can describe the shapes, sponge gourd, pumpkin, and bottle gourd. 1-2. The students can describe the crawling phenomena of the said four plants.

$1-3$. The students can describe the fruits situation of the said four plants.

2. The students can describe at least 5 principles for composition.

3. The students can explain the appropriate position for commentaries.

4-1. The students can paint out the feeling of pen touch and the change of ink color in thickness, thinness, dry, moisture, and withering.

4-2. The students can imitate a simple demonstrated work or picture.

5. The students can imitate the work to paint out a similar work.

6. The students can put commentaries in the appropriate place in the painting.

7. The students will demonstrate a profund understanding of Chinese paintings and find a personal interest and accept once.

8. The students will show interest in the amazing changes of the brush pens and ink colors and to résearch it in order to create wonderful works.

9. The students will show an understanding of the broadness and profoundness of the Chinese culture. 


\begin{tabular}{|c|c|c|c|c|}
\hline$\left\{\begin{array}{l}\text { ouchims } \\
\text { Cioal }\end{array}\right.$ & & Toaching Tools & lime & Appraisal \\
\hline & $\begin{array}{l}\text { A. preparatory activities } \\
\text { 1. Teacher: } \\
\text { (1) Textbooks. } \\
\text { (2) Demonstrated works. } \\
\text { (3) Pictures. } \\
\text { (4) Lantern slide, } \\
\text { slide projector. } \\
\text { (5) Projective film, Transparen } \\
\text { Card } \\
\text { (6) Related picture book. } \\
\text { (7) Painting supplies. } \\
\text { 2. Students: } \\
\text { (1) Textbooks. } \\
\text { 2. Decision for purpose: } \\
\text { After the said studying and } \\
\text { explanations. the Chinese } \\
\text { (2) Used papers, cloth cushion } \\
\text { growing process and making } \\
\text { or dish cloth, tissue paper } \\
\text { (2) To submit pictures for } \\
\text { towel. } \\
\text { (3) Collect related pictures or } \\
\text { painting collections. } \\
\text { (4) Painting supplies. } \\
\text { groveloping Activities: } \\
\text { vegetables, and fruits which } \\
\text { (1) To study the shapes and } \\
\text { (2) life. } \\
\text { (3) names and } \\
\text { (1) have during } \\
\text { (1) }\end{array}$ & $\begin{array}{l}\text { real object } \\
" \\
" \\
" \\
\text { " } \\
\text { " } \\
\text { " } \\
\text { real } \\
\text { object } \\
\text { projector } \\
\text { pictures }\end{array}$ & 10 & \\
\hline
\end{tabular}




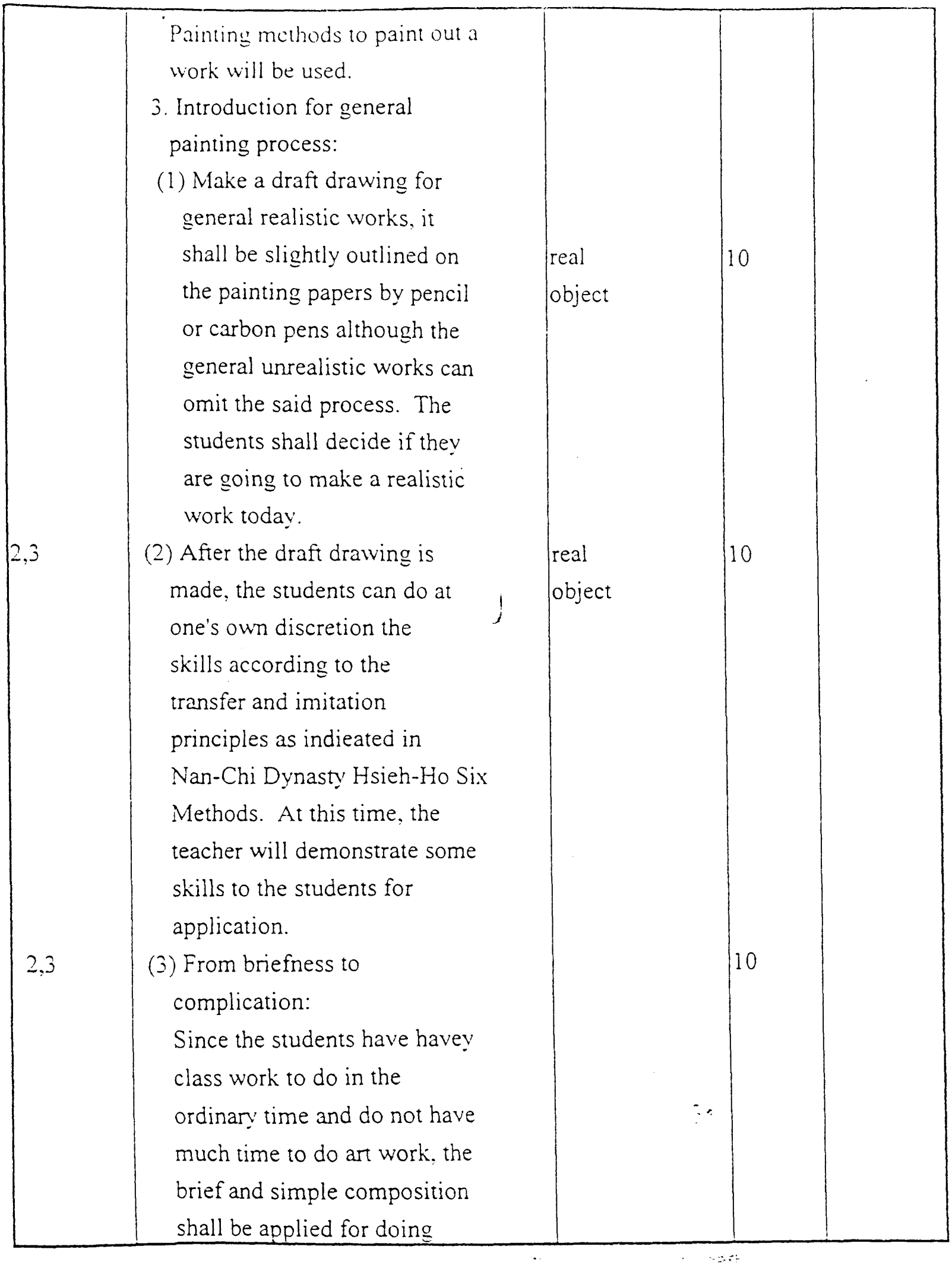


this painting.

(4) Principle of composition:

a. Having ready designs:

Having ready designs in

one.s mind before starting painting.

b. Selecting situations:

There are three kinds of selecting situations--inserting on top, falling domn, and horizontal lying, which shall be decided according to natural ecoloby. In other words, the principle of image shapes or pictographs as indicated in $\mathrm{Han}-\mathrm{Chi}$ Dynasty Hsieh-Ho Six Methods.

c. Make sure the positions for subjective and objective:

- Principally, the objective shall be positioned at the center or the important part of picture. The balance between subjective and objective must be acquired. which is the principle of position managing as indica indicated in Nan-Chi Dynasty Hsieh-Ho Six Methods.

d. Looseness and density: Looseness and density can produce attractive pictures. During painting, you should consider producing a virtual as well as realistic picture at all times.

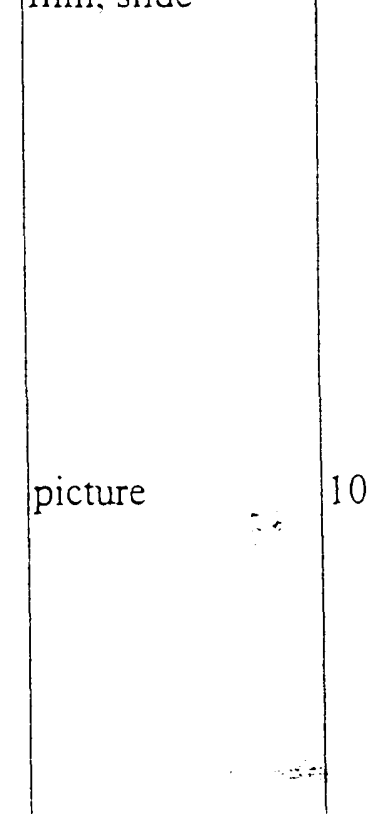




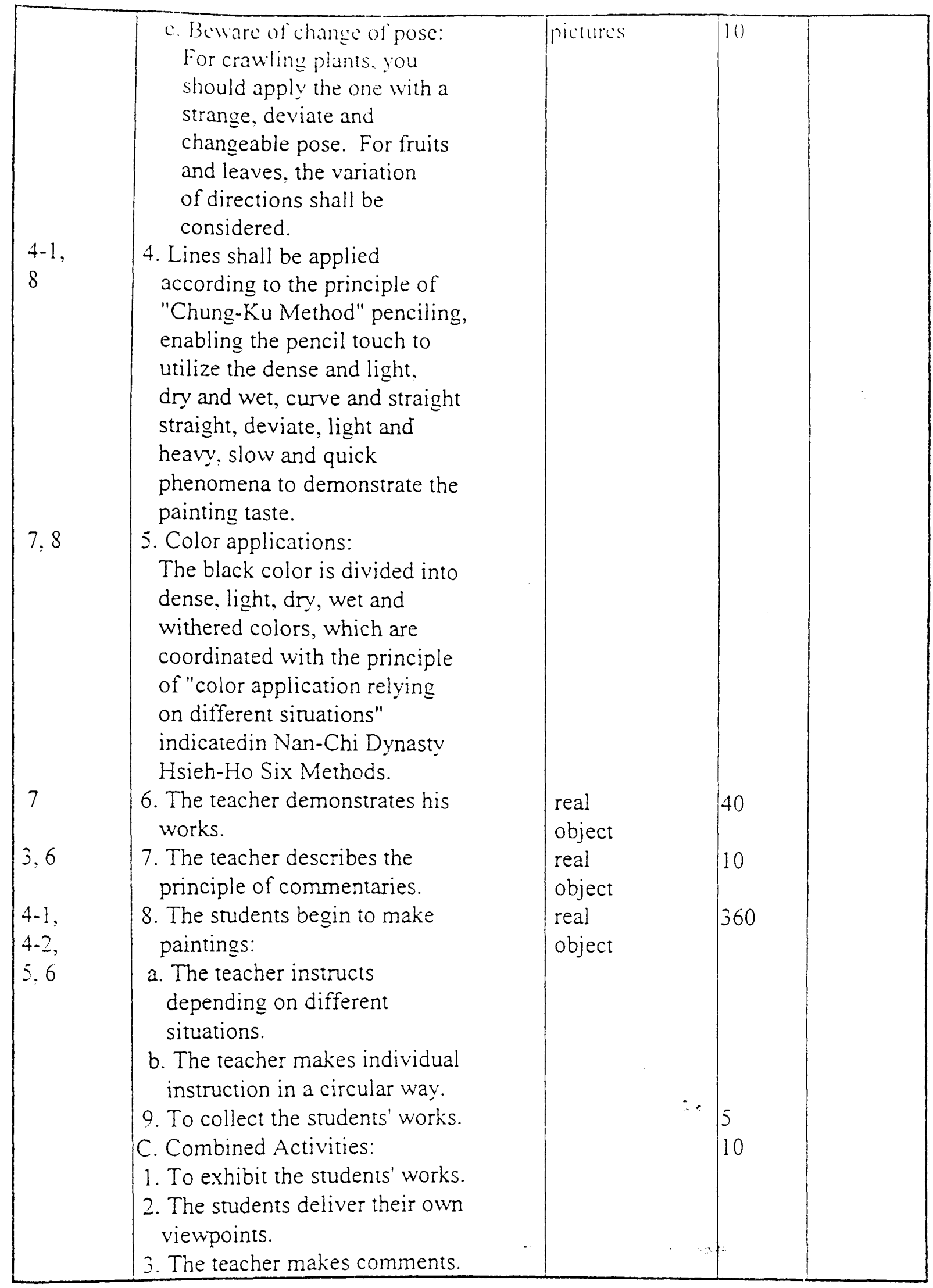




\begin{tabular}{|l|l|l|l|l|}
\hline $\begin{array}{l}\text { 4. The teacher prepares the } \\
\text { guestions to test the related } \\
\text { knowledge the students should } \\
\text { know. } \\
\text {-..--.-This unit is closed---- }\end{array}$ & & & \\
\hline
\end{tabular}




\begin{abstract}
I
APPENDIX C:

ACTIVITY TABLE FOR THE FIRST YEAR STUDENT

IN CHINESE PAINTING APPRECIATION EDUCATION

EXPERIMENTAL GROUP
\end{abstract}


APPENDIX C: Activity Table for the First Year Student in Chinese Painting Appreciation Education, Experimental Group

\begin{tabular}{|c|c|}
\hline Unit: & Chinese painting form, set up, pen stroke and color \\
\hline Class & $\begin{array}{l}\text { Forst school year of common } \\
\text { class }\end{array}$ \\
\hline Source of person & $\begin{array}{l}\text { Jing Hud } 39 \\
\text { Ming Yi } 42 \\
\text { Tong Hdi } 45\end{array}$ \\
\hline $\begin{array}{l}\text { Source of Taught } \\
\text { meterial }\end{array}$ & Self-Compilation \\
\hline Teacher & Shen, Hsiu Hsiung \\
\hline Object: & Junior High School student in ordinary class \\
\hline Material Research: & $\begin{array}{l}\text { (1) Understand the theoretical foundation of form, set } \\
\text { up, pen stroke and color in Chinese painting. (2) Know } \\
\text { the symbolic traditional and modern artists, and their } \\
\text { important works. (3) Judge the works. (4) Learn the } \\
\text { special characteristics of Chinese painting tools. } \\
\text { (5) Know the different Chinese painting themes and its } \\
\text { presentation techniques. }\end{array}$ \\
\hline $\begin{array}{l}\text { Teaching Method: } \\
\text { Teaching Resources: }\end{array}$ & $\begin{array}{l}\text { Lecture, appreciation, examples, presentation, exchange } \\
\text { of views, comparison, and discussion. } \\
\text { (1) Slides, (2) transparencies, (3)drawings, books, } \\
\text { (4) enlarged pictures, (5) self-made drawings, cards, } \\
\text { (6) books. (7) blackboards. chalk }\end{array}$ \\
\hline
\end{tabular}




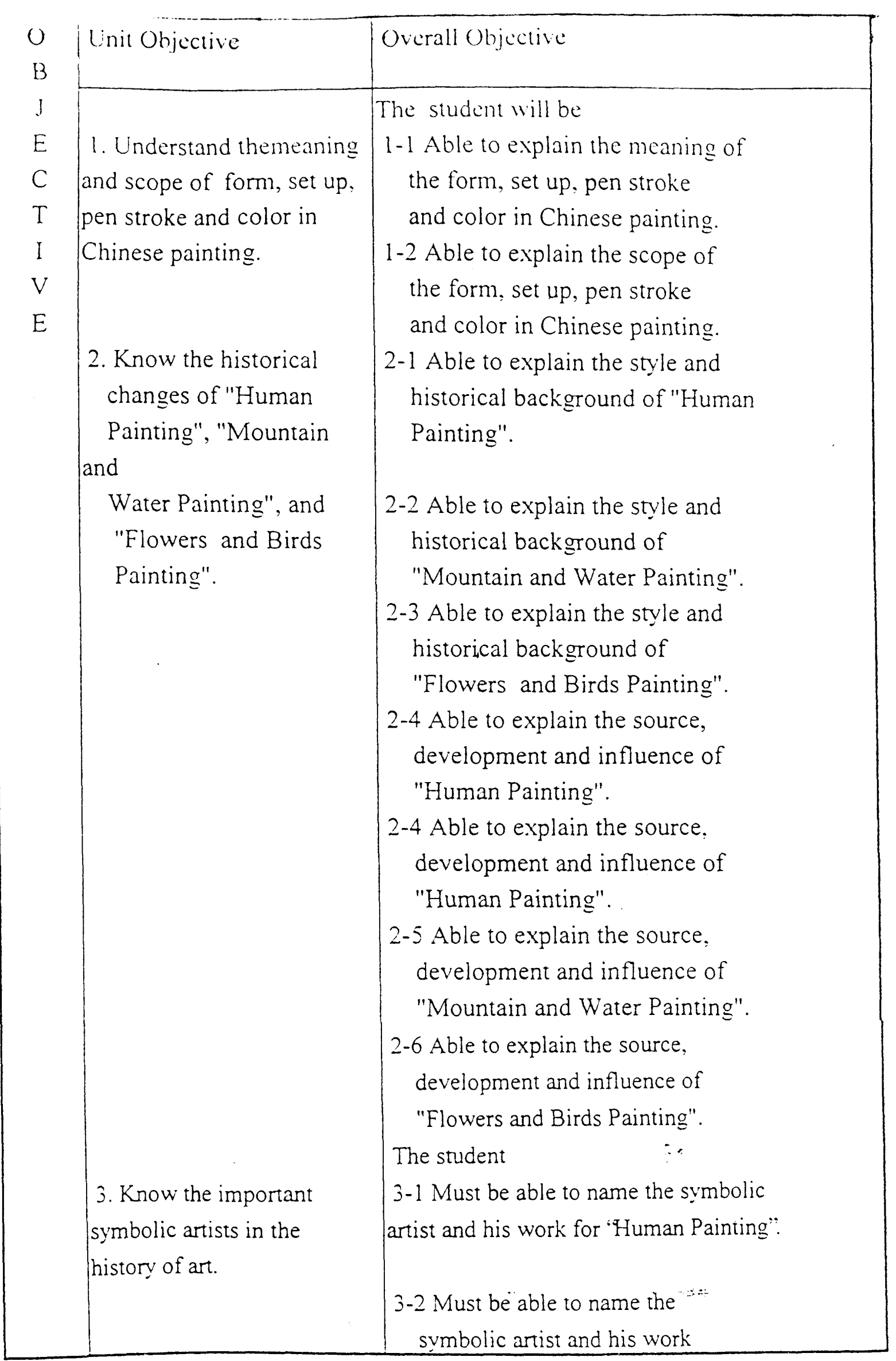




\begin{tabular}{|c|c|}
\hline $\begin{array}{l}\text { 5. Understand the relation } \\
\text { between the artist and the } \\
\text { historical background at } \\
\text { that time. } \\
\text { 6. Know the theme and } \\
\text { objects depicted by the work. }\end{array}$ & $\begin{array}{l}\text { for "Mountain and Water } \\
\text { Painting." } \\
\text { 3-3 Must be able to name the } \\
\text { symbolic artist and his work } \\
\text { for "Flowers and Birds } \\
\text { Painting". } \\
\text { 4-1 Can tell what Name the artist } \\
\text { of an object. } \\
\text { 4-2 Can differentiate the special } \\
\text { styles of different artists. } \\
\text { 4-3 Can tell the characteristics of } \\
\text { different human paintings. } \\
\text { 4-4 Can tell the characteristics of } \\
\text { different mountain and water } \\
\text { paintings. } \\
\text { 4-5 Can tell the characteristics of } \\
\text { different flowers and birds } \\
\text { paintings. } \\
\text { 5-1 Must be able to explain the } \\
\text { influence of the historical } \\
\text { background on the works of the } \\
\text { artist. } \\
\text { 5-2 Must be able to explain the } \\
\text { influence of the artist on the } \\
\text { painting scene at that time and } \\
\text { after. } \\
\text { 6-1 Can tell the theme of the work. } \\
\text { 6-2 Can tell the objects depicted } \\
\text { in the work. }\end{array}$ \\
\hline
\end{tabular}


7. Know the form. set up, pen strokes,black ink and color used in the work.

8. Understand the concept, feeling and meaning of works

9. Judge the artistic value of works, give his own comments.

10. Know the types, characteristics, functions of Chinese paintings.

11. Know the 5 basic expression techniques.
7-1 Able to explain the drawing styles of different works.

7-2 Able to explain the set up styles of different works.

7-3 Able to explain use of pen strokes in different works.

7-4 Able to explain use of inks and colors in different works.

8-1 Able to explain the concept of the artist in creating his work.

8-2 Able to explain the feeling in the whole work.

8-3 Able to explain the meaning expressed by the artist in his work.

8-4 Able to appropriate words to describe the feelings toward the work.

9-1 Able to express personal comments on the artistic value of works and the reasons.

9-2 Able to about personal favorite works and reasons for liking them.

10-1 Able to the different types, characteristics and functions of Chinese paintings.

11-1 Able to Name the expression techniques for different works.

11-2 Able to tell the effect created by different techniques. 


\begin{tabular}{|c|c|c|c|c|c|}
\hline $\begin{array}{l}\text { objec- } \\
\text { tive }\end{array}$ & Teacherstetivilies & $\begin{array}{l}\text { Sudents' } \\
\text { Activities }\end{array}$ & $\begin{array}{l}\text { Maching } \\
\text { Material }\end{array}$ & Time & $\begin{array}{l}\text { Evaluatiest } \\
\text { and Remarks }\end{array}$ \\
\hline & $\begin{array}{l}\text { I. Preparation: } \\
\text { 1. Collect relevant } \\
\text { data on form,set } \\
\text { up. pen strokes. } \\
\text { and color. } \\
\text { 2. Make slides and } \\
\text { prepare the } \\
\text { projector. } \\
\text { 3. Enlarge figures } \\
\text { and drawings } \\
\text { of works. } \\
\text { 4. Make transparen } \\
\text { cies and prepare } \\
\text { the projector. } \\
\text { 5. Prepare Chinese } \\
\text { painting tools. } \\
\text { these themes. } \\
\text { 2. Introduce the } \\
\text { contents and } \\
\text { Introduction: } \\
\text { 1. Ask if the } \\
\text { students had } \\
\text { attended Chinese } \\
\text { painting classes } \\
\text { before, and which } \\
\text { theme they like } \\
\text { best(mountain and } \\
\text { water,flowers } \\
\text { and birds, people } \\
\text { or others). Ask }\end{array}$ & $\begin{array}{l}\text { Bring notebook } \\
\text { for taking } \\
\text { notes starting } \\
\text { from the first } \\
\text { class session. } \\
\text { Collect relevant } \\
\text { books and } \\
\text { figures. } \\
\text { kaise the hand } \\
\text { for expressing } \\
\text { comments, } \\
\text { then describe } \\
\text { the views, } \\
\text { knowledge } \\
\text { and concepts. }\end{array}$ & $\begin{array}{l}\text { black=- } \\
\text { board. }\end{array}$ & $\begin{array}{l}B \\
c \\
r \\
p\end{array}$ & $\begin{array}{l}\text { Bring and } \\
\text { collect } \\
\text { relevant } \\
\text { pictures. }\end{array}$ \\
\hline
\end{tabular}




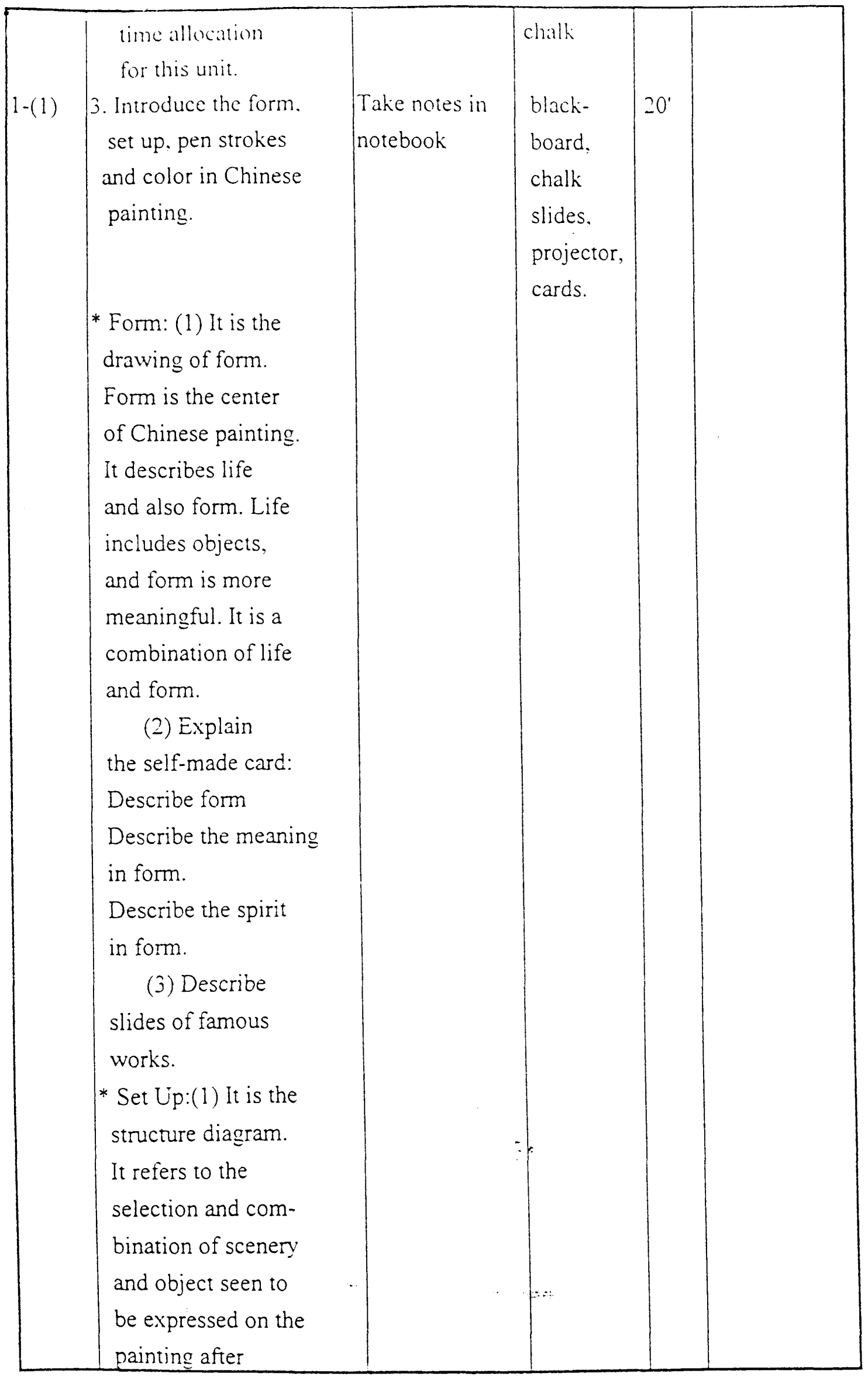




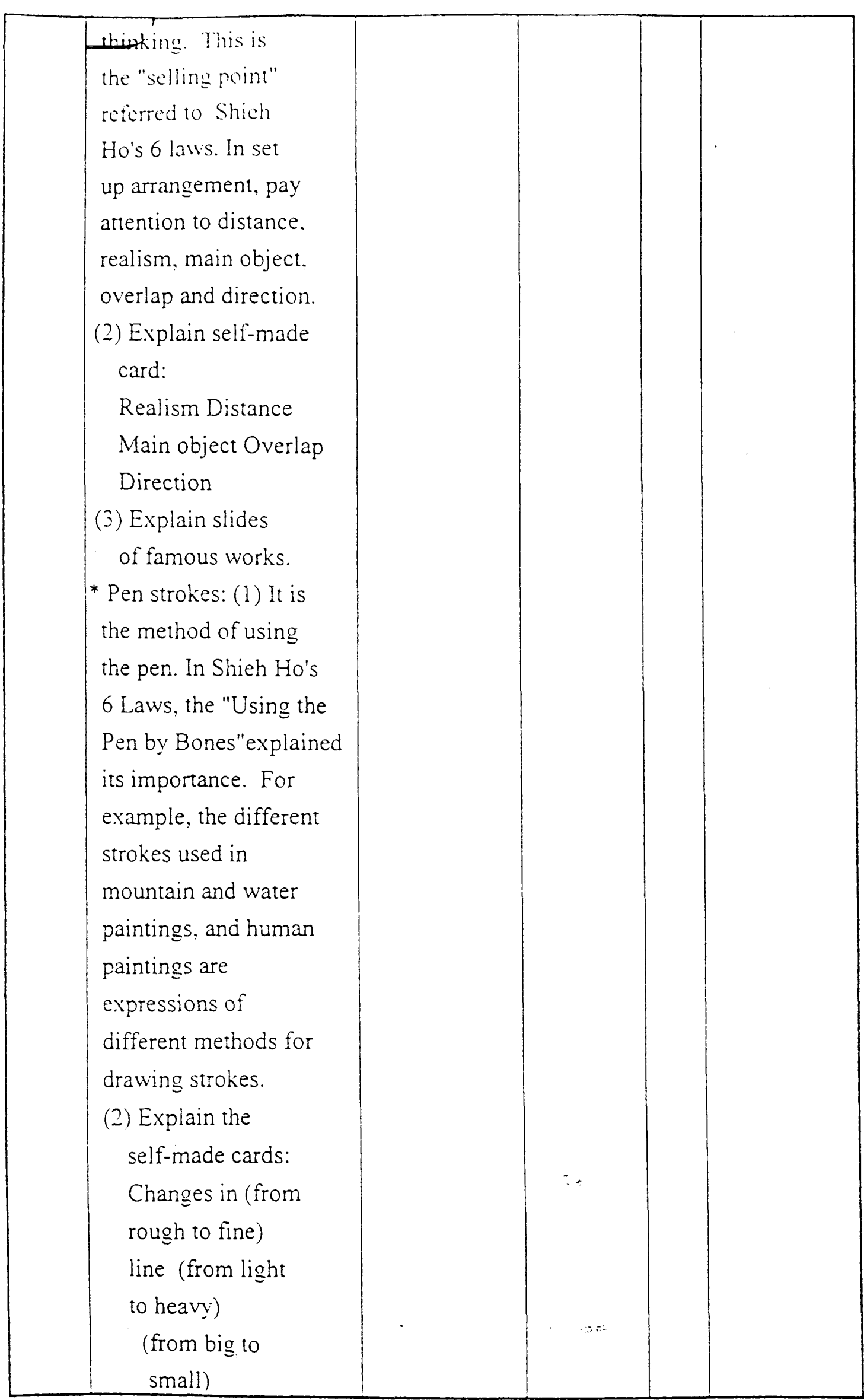


(3) Explain the slides of famous works.

* Color:

(1) It is the meaning of coloring or dyeing colors. In Chinese painting, colors are usually based on natural sceneries and objects. This is what one of Shieh Ho's 6 Laws mean by "Follow the type in giving color". The color in Chinese painting is based on black ink. Black ink can be dry, wet, dark, light or black. There is a great variety of color. These colors can be mixed using water or resin on the brush or palette.

(2) Explain the self-made cards:

Changes in black ink:

A. from dark to light.

B. from dry to wet.

C. from fast to slow. Changes in color: hematite vellow. 


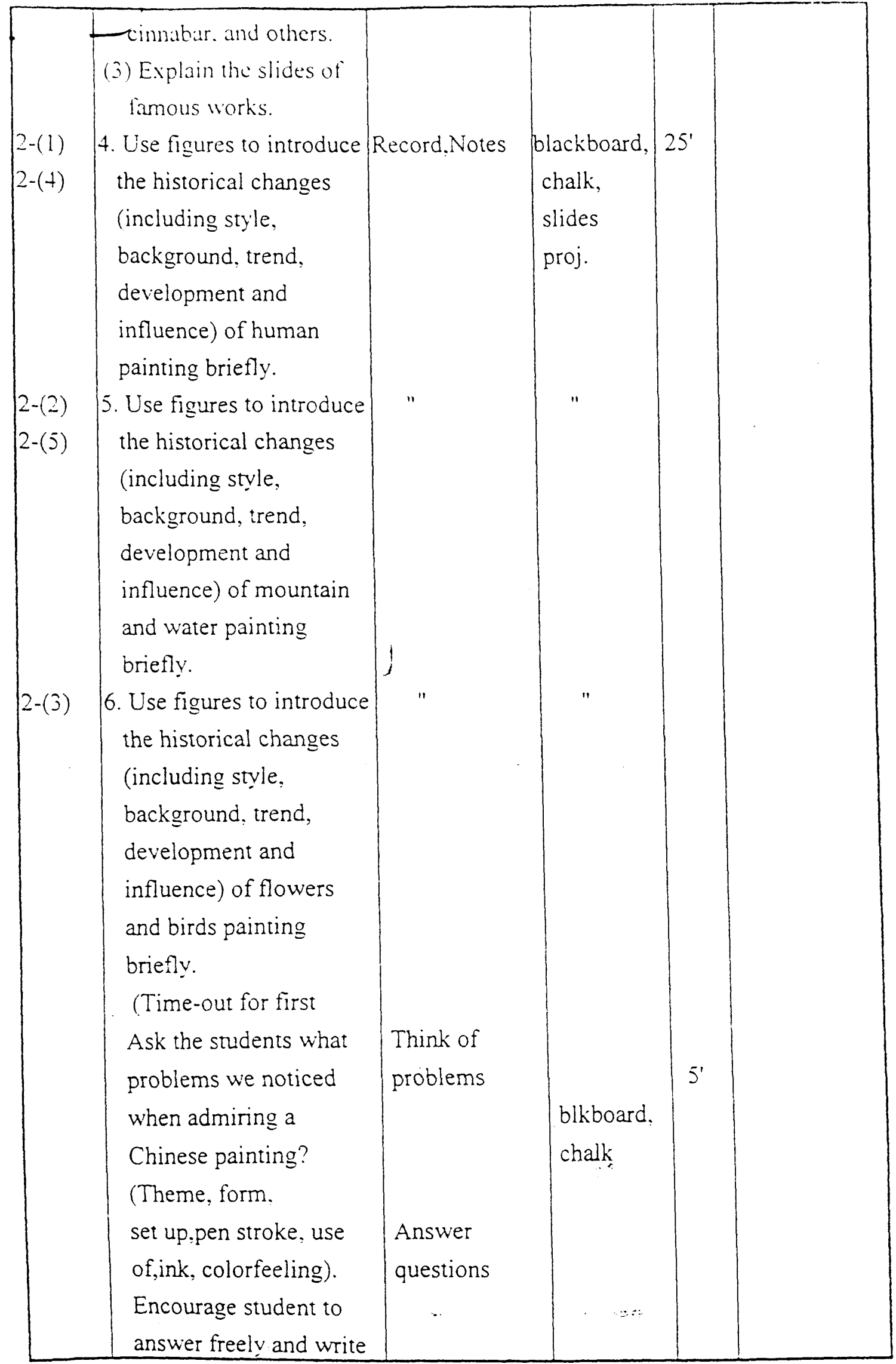




\begin{tabular}{|c|c|c|c|c|c|}
\hline$\left\{\begin{array}{l}7-(2) \\
7-(3) \\
8-(1)\end{array}\right.$ & $\begin{array}{l}\text { the answicrs on the } \\
\text { blackboard Check and } \\
\text { teach the correct } \\
\text { terminology. } \\
\text { III. Warm-up activity: } \\
\text { (1) Human painting } \\
\text { 1. Brief introduction of } \\
\text { symboic artists and } \\
\text { their works. } \\
\text { 2. Show slides of symbol } \\
\text { human painting artists } \\
\text { and lead the students } \\
\text { to judge the work by } \\
\text { exchanging views. } \\
\\
\text { Example: painting of a } \\
\text { woman } \\
\text { (1) What is the theme? } \\
\text { (beautiful woman) } \\
\text { (2) Describe what this } \\
\text { painting is } \\
\text { expressing. } \\
\text { (3) How are the crises in } \\
\text { the woman's robe } \\
\text { expressed? } \\
\text { (4) What are the hidden } \\
\text { meanings that the } \\
\text { artist is trying to } \\
\text { tell us? } \\
\text { (5) Describe your feelings this a good or bad } \\
\text { t6 why? }\end{array}$ & $\begin{array}{l}\text { Carefully } \\
\text { view each } \\
\text { part of the } \\
\text { work, and } \\
\text { express } \\
\text { personal } \\
\text { ppinions. }\end{array}$ & $\begin{array}{l}\text { blkboard, } \\
\text { chalk, } \\
\text { slides, } \\
\text { proj. }\end{array}$ & $20^{\prime}$ & $\begin{array}{l}\text { Encourage } \\
\text { students to } \\
\text { observe } \\
\text { work and } \\
\text { give } \\
\text { opinions. } \\
\text { Do not or } \\
\text { comment or } \\
\text { correct the } \\
\text { opinions. } \\
\\
\text { The teacher } \\
\text { gives the } \\
\text { appropriate } \\
\text { terminology } \\
\text { at certain } \\
\text { conditions } \\
\text { to lead the } \\
\text { students to } \\
\text { describe. }\end{array}$ \\
\hline
\end{tabular}




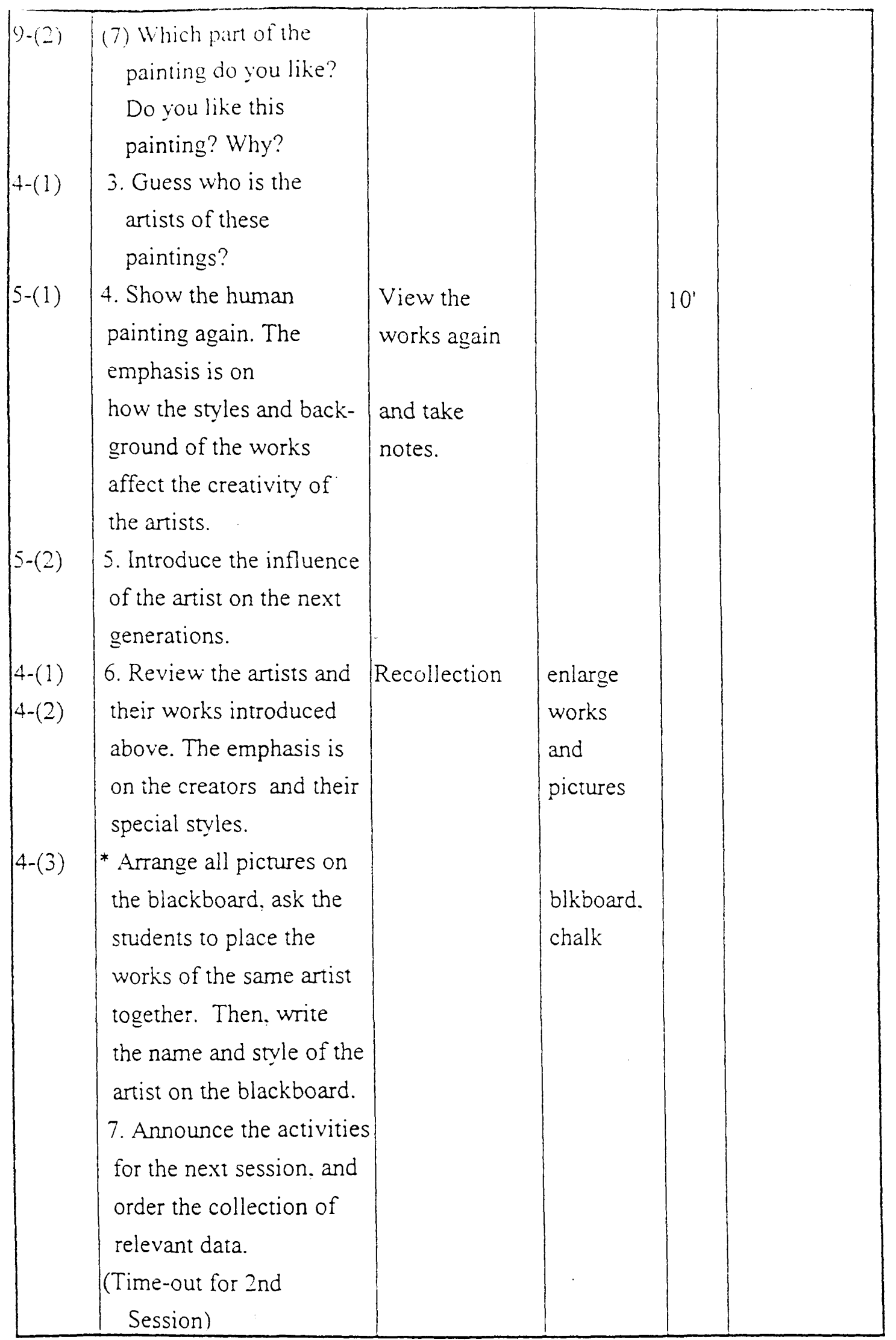




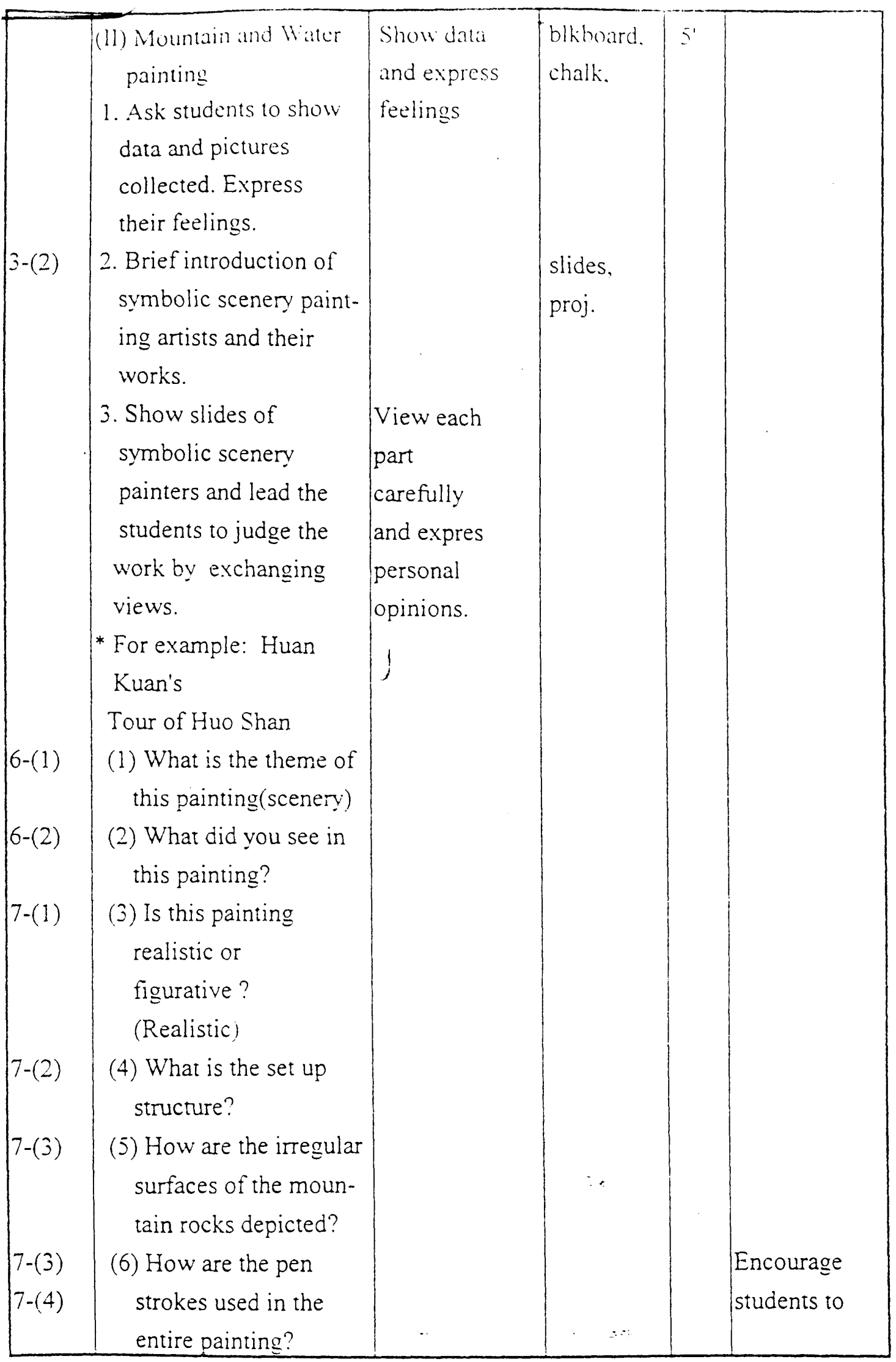




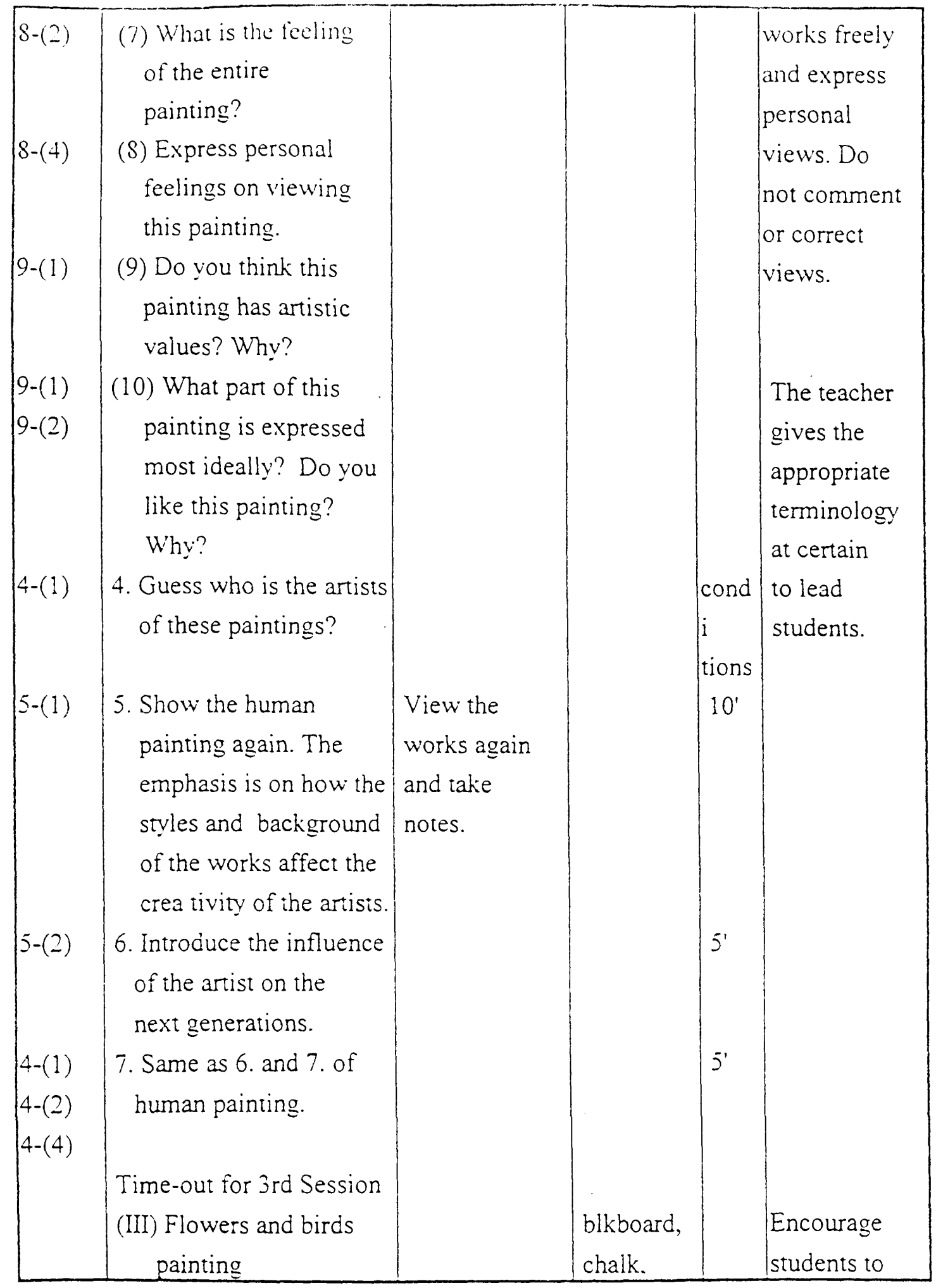




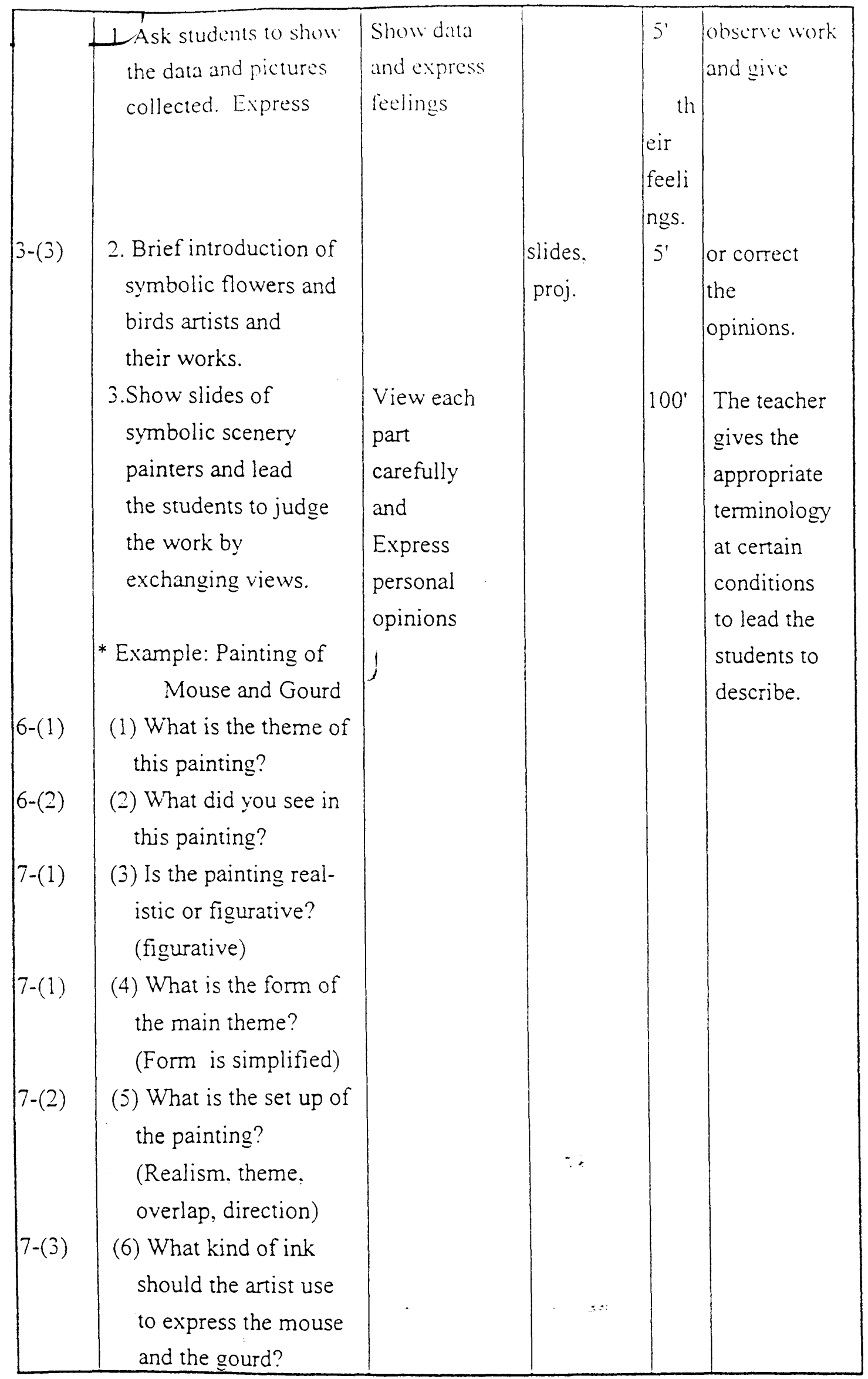




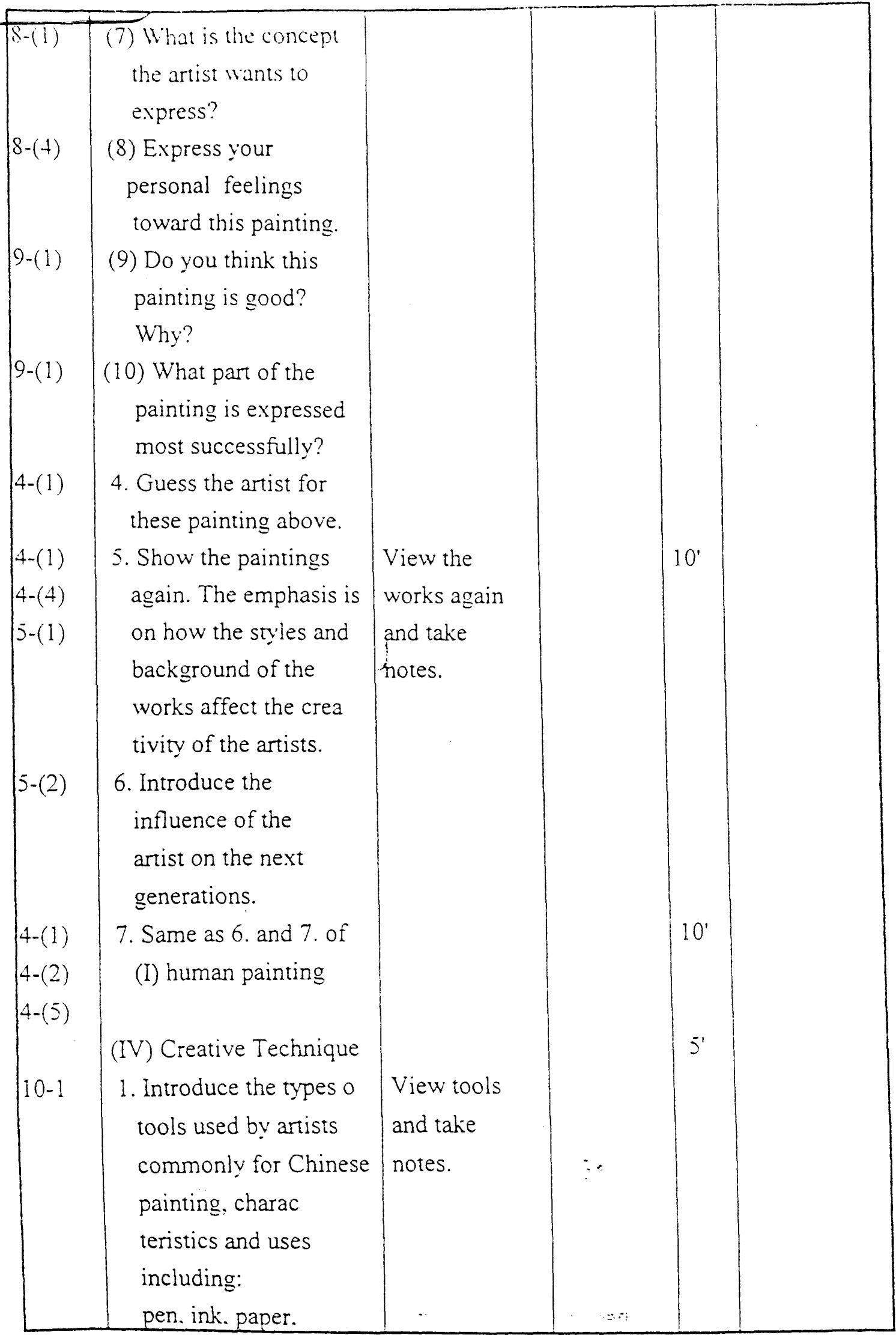




\begin{tabular}{|c|c|c|c|c|c|}
\hline $11-(1)$ & 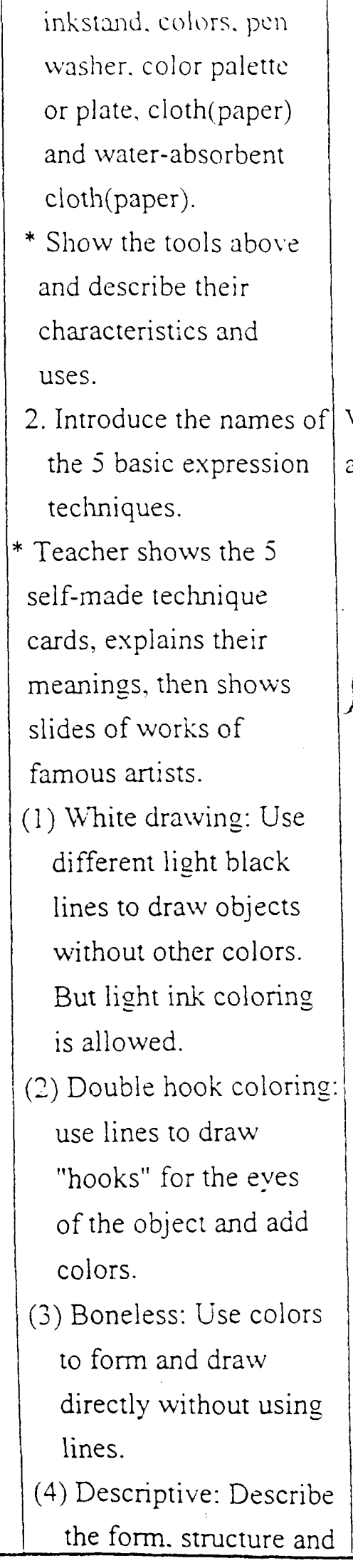 & $\begin{array}{l}\text { View cards } \\
\text { and slides } \\
\text { a }\end{array}$ & $\begin{array}{l}\text { blkboard, } \\
\text { chalk, } \\
\text { slides. } \\
\text { proj. }\end{array}$ & $20^{\prime}$ & $\begin{array}{l}\text { Name and } \\
\text { identify } \\
\text { effects } \\
\text { created by } \\
\text { the } \\
\text { different } \\
\text { techniques. }\end{array}$ \\
\hline
\end{tabular}




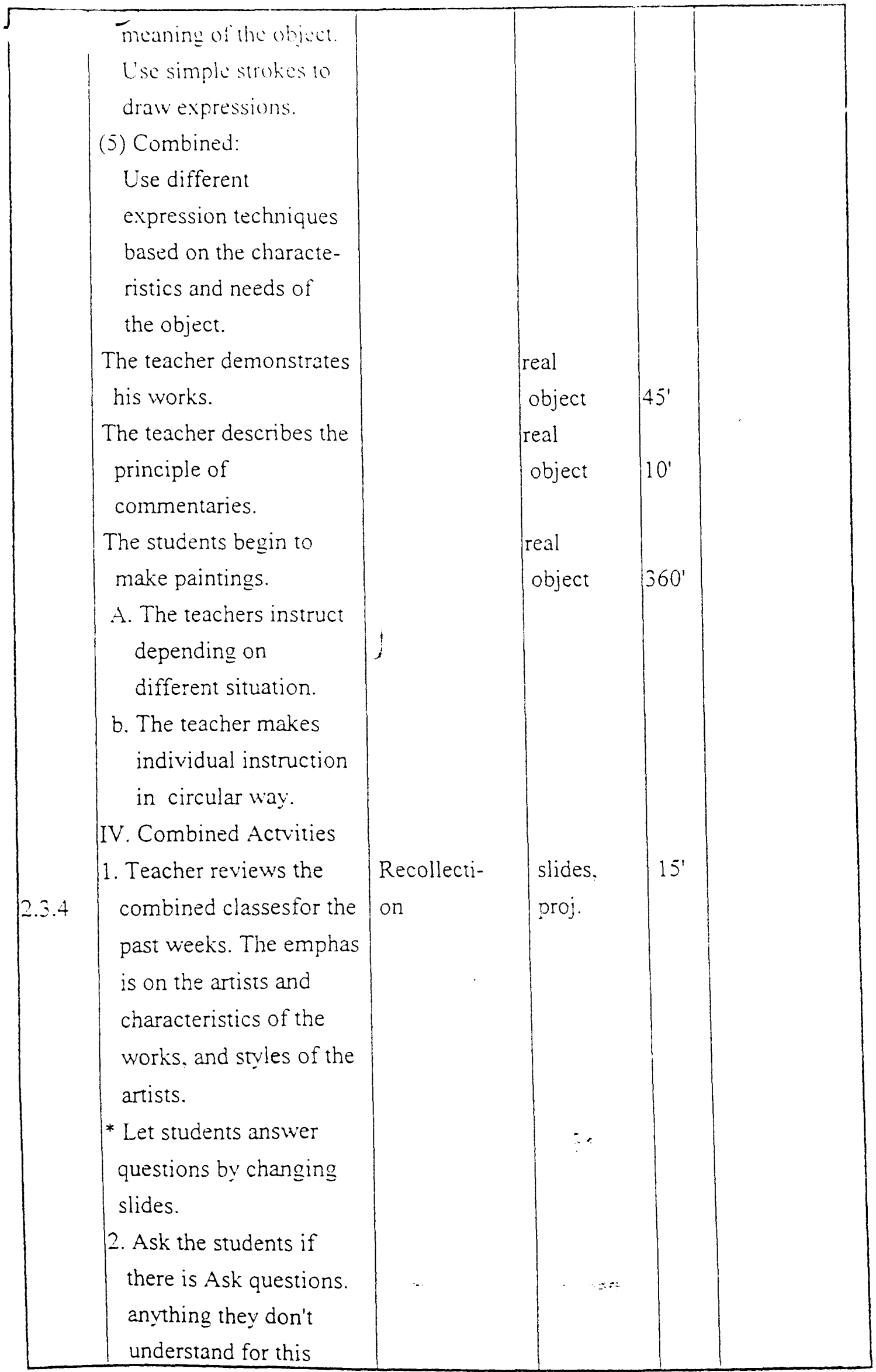




\begin{tabular}{|c|c|c|}
\hline $\begin{array}{l}\text { unit? Tell students to } \\
\text { ask questions. } \\
\text { 3. Is there any feelings } \\
\text { after weeks of classes? } \\
\text { What are the } \\
\text { difficulties? What did } \\
\text { they learn? Express } \\
\text { feelings. } \\
\text {-This unit is closed- }\end{array}$ & $\begin{array}{l}\text { Express } \\
\text { feelings }\end{array}$ & $\begin{array}{l}\text { Express } \\
\text { personal } \\
\text { feelings. } \\
\text { difficulties } \\
\text { and } \\
\text { achievements } \\
\text { from } \\
\text { attending } \\
\text { this class. }\end{array}$ \\
\hline
\end{tabular}


J

APPENDIX D:

THE POSTTEST OF KNOWLEDGE 
APPENDIX D: The Posttest of Knowledge

Directions: Fill in the blanks.

1. Chinese painting's main stream is the (monochrome ink painting).

2. The art of using lines made by movements of a brush to describe objects is called (brush technique or stroke art).

3. The four precious things in the chinese studios are and (brushes, ink, paper and ink slabs).

4. The wall painting of Dun Huang began in the period called Southern, and Northern Dynasties), and won fame throughout the world.

5. Among the color substances used for Chinese painting, those which are exracted from minerals are: (coffee, orange, light blue, light green, red and white), from plants: (vermillion red or scarelt red. blue and yellow), and from animals (white powder).

6. That which is written on a painting to indicate the author's real mane, alternative name, studio name, and the date and hour of the painting is called (autograph and data).

7. A piece of poem or lyric handwritten on a calligraphic work or painting as a complimentary close or heading is called (inscription).

8. Seals are classified according to their contencs into five types. namely: (name seal. origin seal. studio seal. good omen deal. and appreciative seal).

9. A painting that is mounted for hanging on the wall is called a scroll).

10. A painting that can be placed on a table and unrolled as one is appreciating it is called a (hand scroll or long scroll).

11. The four binging types of albums are: (single leaf binding, double leaf binding, top binding. and multi-fold binding). 
12. The , and (Tang. Sung, and Yuan) Dynasties are the most flowery periods in Chinese painting history. Paintings of the three dynasties are delicate, refined, and abundant.

13. The Sung Dynasty is more oriented to literary pursuits and less 10 military interests. Paintings of the Sung Dynasty are not only looking for also in quest of (vivid air) and (profundity). (likeness), but

14. The Yuan Dynasty is more oriented to military interests and less to literary pursuits. Artists of the Yuan Dynasty very often use (brush and ink) to express their feelings. As a result, their paintings are not at all looking for brush and ink). (likeness), but only in earnest quest of the (the charm of the

15. (Landscape) is the leading type of painting in Chinese painting history. and has become an art that expresses the spirit of the Chinese national culture.

16. history. (Figure) painting is the earliest form developed in Chinese painting

17. (Gonbi) figure painting describes the objects in an elaborate style.

18. (Xieyi) figure painting describes the objects in a flowing impressionistic style, giving great importance to (the tone and atmosphere) and (the charm of the brush and ink).

19. Please give three names of artists of the Tang Dynasty: (Yen Li-Ben: Han Gan; Li Shi-Shun: Zhou Fang; Bian Ruan; Jing Hao: Guan Chuan; Dong Yuan: Ju Ran: Huang Chuan: and Shu Shi).

20. Please give three names of artists of the Sung Dynasty: (Mi Fei: Fan Kuan: Ma Yuan: Li Tang: Sha Gui: Zhao Chang; Li Gong-Ling; and Su Han-Chen). 


\section{l \\ APPENDIX E: \\ BACKGROUND INFORMATION ABOUT THREE EXPERTS}


APPENDIX L: Background Information about Three Experts

1. Yo-Wu Fu, Professor, Chinese Painting Sub-Division, NTNU; Evaluation committee member of the most famous Fine Arts exhibition.

2. Fan Low, Professor. Chinese Painting Sub Divisio, NTNU; Evaluation committee member of the most famous Fine Arts exhibition.

3. Jan-Chan Mai Fine Arts Teacher, Taipei Municipal Jin-Hwa Junior High School; 25 years in Fine Arts instruction; Evaluation committee member of the most famous Fine Arts exhibition. 
APPENDIX F:

SCORES 
APPENDIX F: Scores

\begin{tabular}{|c|c|c|c|c|c|c|c|c|}
\hline no. & namc & 代 竖 & $\begin{array}{c}\text { pre.t.s. } \\
\text { scorc }\end{array}$ & 代 沙衣 & $\begin{array}{c}\text { pos. n'.s. } \\
\text { scorce }\end{array}$ & $\begin{array}{c}\text { cmotion } \\
\text { score }\end{array}$ & knowleg & total \\
\hline 1 & 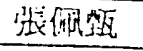 & $\mathrm{K} 1 \mathrm{AO1}$ & D & $\mathrm{K} 1 \mathrm{BO}$ & C & 61 & 40 & \\
\hline 2 & 故雅管 & $\mathrm{K} 1 \wedge 02$ & D & $\mathrm{K} 1 \mathrm{~B} 02$ & $C$ & 79 & 72 & \\
\hline 3 & 際汀吉 & $\mathrm{K} 1 \wedge 03$ & D & $\mathrm{K}] \mathrm{BO} 3$ & $B$ & 60 & 12 & \\
\hline 4 & 張已㼛 & $\mathrm{K} 1 \mathrm{AO4}$ & D & $\mathrm{K} 1 \mathrm{BO} 4$ & $\mathrm{C}$ & 56 & 64 & \\
\hline 5 & 宫秉港 & $\mathrm{K} 1 \wedge 05$ & D & $\mathrm{K} 1 \mathrm{BO} 5$ & $A$ & 63 & 54 & \\
\hline 6 & 姜怡悹 & $\mathrm{K} 1 \mathrm{AO} 6$ & D & $\mathrm{K} 1 \mathrm{BO} 6$ & $B$ & 70 & 56 & \\
\hline 7 & 許佳㻦 & $\mathrm{K} 1 \mathrm{AO} 07$ & D & $\mathrm{K} 1 \mathrm{BO}$ & B & 73 & 34 & \\
\hline 8 & 黃于芝 & $\mathrm{K} 1 \mathrm{AO} 8$ & C & $\mathrm{K} 1 \mathrm{BO} 8$ & $\mathrm{C}$ & 72 & 30 & \\
\hline 9 & 黃子倫 & $\mathrm{K} 1 \mathrm{AO} 9$ & $D$ & $\mathrm{~K} 1 \mathrm{BO} 9$ & $\mathrm{C}$ & 67 & 46 & \\
\hline 10 & 張零書 & $\mathrm{K} 1 \mathrm{~A} 10$ & $\mathrm{D}$ & $\mathrm{K} 1 \mathrm{~B} 10$ & $\mathrm{C}$ & 55 & 46 & \\
\hline 11 & 巫郁玫 & $\mathrm{K} 1 \mathrm{~A} \perp 1$ & C & $\mathrm{K} 1 \mathrm{~B} 11$ & $\mathrm{C}$ & 53 & 36 & \\
\hline 12 & 翁椯祀 & $K \perp A 12$ & ! & $\mathrm{K} 1 \mathrm{~B} 12$ & $i$ & & 1 & \\
\hline 13 & 赖思穎 & $\mathrm{K} \perp \mathrm{A} \perp 3$ & D & $\mathrm{K} 1 \mathrm{~B} 13$ & $\mathrm{C}$ & 67 & 42 & \\
\hline 14 & 鄭浩云 & $\mathrm{K} \perp \wedge 14$ & C & $\mathrm{K} 1 \mathrm{~B} \perp 4$ & $B$ & 50 & 20 & \\
\hline 15 & 李巂微 & $\mathrm{K} 1 \mathrm{~A} 15$ & D & $\mathrm{K} 1 \mathrm{~B} 15$ & $\mathrm{~B}$ & 33 & 38 & \\
\hline 16 & 陳方佩 & $\mathrm{K} 1 \mathrm{~A} 16$ & D & $\mathrm{K} \perp \mathrm{B} 16$ & $\mathrm{C}$ & 73 & 52 & \\
\hline 17 & 施秀英 & $K \perp A 17$ & D & $\mathrm{K} \perp \mathrm{B} \perp 7$ & $\mathrm{C}$ & 61 & 16 & \\
\hline 18 & 夈明怔 & $K \perp \wedge 18$ & D & $\mathrm{K} 1 \mathrm{~B} 18$ & $B$ & 73 & 48 & \\
\hline 19 & 林培珊 & $\mathrm{K} 1 \mathrm{~A} 19$ & D & $\mathrm{K} \perp \mathrm{B} \perp 9$ & $\mathrm{C}$ & 65 & 34 & \\
\hline 20 & 林家宏 & $\mathrm{K} 1 \mathrm{~A} 20$ & 1 & $\mathrm{~K} \perp \mathrm{B} 20$ & 1 & & $!$ & \\
\hline 21 & 辟覀志 & $\mathrm{K} 1 \mathrm{~A} 21$ & $\mathrm{D}$ & $\mathrm{K} 1 \mathrm{~B} 21$ & $\mathrm{C}$ & 50 & 32 & \\
\hline 22 & 榢志維 & $\mathrm{K} 1 \mathrm{~A} 22$ & $\mathrm{C}$ & $\mathrm{K} 1 \mathrm{~B} 22$ & $\mathrm{C}$ & 59 & 54 & \\
\hline 23 & 呉宗迪 & $\mathrm{K} 1 \mathrm{~A} 23$ & D & $\mathrm{K} 1 \mathrm{~B} 23$ & $\mathrm{C}$ & 45 & 52 & \\
\hline 24 & 紀明估 & $\mathrm{K} 1 \mathrm{~A} 24$ & D & $\mathrm{K} 1 \mathrm{~B} 24$ & C & 24 & 16 & \\
\hline 25 & 歌寻銘 & $\mathrm{KI} A 25$ & $D$ & $\mathrm{~K} 1 \mathrm{B2} 5$ & B & 50 & 46 & \\
\hline 26 & 撙鲄超 & $\mathrm{K} 1 \mathrm{~A} 26$ & D & $\mathrm{K} 1 \mathrm{~B} 26$ & $D$ & 57 & 32 & \\
\hline 27 & 䧅交䔉 & $\mathrm{K} 1 \mathrm{~A} 27$ & D & $\mathrm{H} 1 \mathrm{~B} 27$ & $C$ & 56 & 31 & \\
\hline 28 & 社士㑨 & $K 1 A 28$ & D & $\mathrm{K} 1 \mathrm{~B} 28$ & $C$ & 76 & 40 & \\
\hline 29 & 涱家言 & $K \perp \wedge 29$ & $\mathrm{D}$ & $\mathrm{K} 1 \mathrm{~B} 29$ & $C$ & 47 & 38 & \\
\hline 30 & 商奕豪 & $\mathrm{K} 1 \mathrm{~A} 30$ & $D$ & $\mathrm{~K} 1 \mathrm{~B} 30$ & $\mathrm{~B}$ & 68 & 52 & \\
\hline 31 & 李冠緯 & $\mathrm{K} 1 \mathrm{~A} 31$ & $\mathrm{C}$ & $\mathrm{K} 1 \mathrm{~B} 31$ & C & 27 & 14 & \\
\hline 32 & 蔣寽蛋 & $\mathrm{K} 1 \mathrm{~A} 32$ & D & $\mathrm{K} 1 \mathrm{~B} 32$ & D & 70 & 18 & \\
\hline 33 & 方致文 & $\mathrm{K} 1 \mathrm{~A} 33$ & $C$ & $\mathrm{~K} 1 \mathrm{~B} 33$ & C & 76 & 26 & \\
\hline 34 & 梁浩涁 & $\mathrm{K} 1 \mathrm{A34}$ & D & K 1 B 34 & $\mathrm{C}$ & 46 & 26 & \\
\hline 35 & 岳鈺斌 & $\mathrm{K} 1 \mathrm{~A} 35$ & D & $\mathrm{K} 1 \mathrm{~B} 35$ & C & 43 & 28 & \\
\hline 36 & 嚴智弘 & $\mathrm{K} 1 \mathrm{~A} 36$ & $\mathrm{C}$ & $\mathrm{K} 1 \mathrm{~B} 36$ & $\mathrm{C}$ & 54 & 36 & \\
\hline 37 & 鐵介介䁑 & $K 1 A 37$ & D & $\mathrm{K} 1 \mathrm{~B} 37$ & $\mathrm{C}$ & 51 & 22 & \\
\hline 38 & 镜守禮 & $\mathrm{K} \perp \mathrm{A} 38$ & D & K $1 B 38$ & D & 38 & 24 & \\
\hline 39 & 江南逻 & $\mathrm{K} 1 \mathrm{~A} 39$ & D & $\mathrm{K} 1 \mathrm{~B} 39$ & $C$ & 60 & 6 & \\
\hline 40 & 羅互寧 & $\mathrm{K} 1 \mathrm{~A} 40$ & D & $\mathrm{K} \perp \mathrm{B} \triangle 0$ & $\mathrm{C}$ & 90 & 24 & \\
\hline 41 & 管交迪 & $\mathrm{K} 1 \mathrm{~A} 41$ & $\mathrm{D}$ & $\mathrm{K} 1 \mathrm{~B} 41$ & $\mathrm{C}$ & 49 & 1 & \\
\hline
\end{tabular}




\begin{tabular}{|c|c|c|c|c|c|c|c|c|}
\hline (10). & आis,.. & $12 \quad \cdots$ & $\begin{array}{l}\text { mens } \\
\text { score }\end{array}$ & 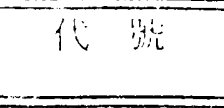 & $\begin{array}{c}\text { pos } w s \\
\text { score }\end{array}$ & $\begin{array}{l}\text { emretion } \\
\text { score }\end{array}$ & hnowledge & tolal \\
\hline 1 & inding & 12101 & D & $\mathrm{K} 2 \mathrm{BO} 1$ & $C$ & 76 & 70 & \\
\hline 2 & 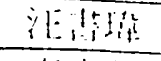 & $\mathrm{h} 2 \wedge 02$ & $\mathrm{D}$ & $\mathrm{k} 2 \mathrm{BO} 2$ & D & 33 & 72 & \\
\hline 3 & 李亩挹 & $K 2 A 03$ & $\mathrm{D}$ & $\mathrm{K} 2 \mathrm{BO}$ & C & 81 & 76 & \\
\hline 4 & 惏文喻 & $K 2 A 04$ & $\mathrm{~B}$ & $\mathrm{~K} 2 \mathrm{BO}$ & $C$ & 72 & 42 & \\
\hline 5 & 张雅酒 & $\mathrm{K} 2 \mathrm{A05}$ & $\mathrm{D}$ & $\mathrm{K} 2 \mathrm{BO} 5$ & C & 84 & 48 & \\
\hline 6 & 林泟如 & $\mathrm{K} 2 \mathrm{AO} 6$ & $\mathrm{D}$ & $\mathrm{K} 2 \mathrm{BO}$ & $\mathrm{C}$ & 82 & 44 & \\
\hline 7 & 谢们国师 & $\mathrm{K} 2 \mathrm{AO}$ & $\mathrm{D}$ & $\mathrm{K} 2 \mathrm{BO} 07$ & $\mathrm{~B}$ & 71 & 68 & \\
\hline 8 & 陳㞺犖获 & $\mathrm{K} 2 \mathrm{AO} 08$ & D & $\mathrm{K} 2 \mathrm{BO} 0$ & $\mathrm{C}$ & 67 & 60 & \\
\hline 9 & 获玉琪 & $\mathrm{K} 2 \mathrm{AO} 9$ & D & $\mathrm{K} 2 \mathrm{BO} 9$ & $\mathrm{C}$ & 45 & 46 & \\
\hline 10 & 朱郁婷 & $\mathrm{K} 2 \mathrm{~A} 10$ & $\mathrm{D}$ & $\mathrm{K} 2 \mathrm{~B} 10$ & $\mathrm{C}$ & 77 & 34 & \\
\hline 11 & 王瑋佯 & $\mathrm{K} 2 \mathrm{A1} 1$ & $B$ & $\mathrm{~K} 2 \mathrm{~B} 11$ & $\mathrm{C}$ & 73 & 32 & \\
\hline 12 & 陳䫓如 & $\mathrm{K} 2 \mathrm{~A} 12$ & $\mathrm{D}$ & $\mathrm{K} 2 \mathrm{~B} \mathrm{I} 2$ & $C$ & 63 & 24 & \\
\hline 13 & 徐琶雯 & $\mathrm{K} 2 \mathrm{~A} 13$ & $C$ & $\mathrm{~K} 2 \mathrm{~B} 13$ & $\mathrm{C}$ & 94 & 56 & \\
\hline 14 & 許靜茲 & $\mathrm{K} 2 \mathrm{~A} 14$ & $\mathrm{D}$ & K2B 14 & $\mathrm{C}$ & 50 & 29 & \\
\hline 15 & 錢怡君 & $\mathrm{K} 2 \mathrm{~A} 15$ & $\mathrm{D}$ & $\mathrm{KcB} 15$ & C & 77 & 54 & \\
\hline 16 & 期若蓄 & $\mathrm{K} 2 \mathrm{~A} 16$ & $\mathrm{D}$ & $\mathrm{K} 2 \mathrm{~B} 16$ & C & 79 & 16 & \\
\hline 17 & 龍永潔 & $K 2 A 17$ & D & $\mathrm{K} 2 \mathrm{~B} 17$ & $\mathrm{C}$ & 82 & 60 & \\
\hline 18 & 羅映琁 & $\mathrm{K} 2 \mathrm{~A} 18$ & A & $\mathrm{K} 2 \mathrm{~B} 18$ & $\mathrm{C}$ & 65 & 86 & \\
\hline 19 & 廖婉君 & K2A 19 & D & K 2 B 19 & $\mathrm{~B}$ & 48 & 38 & \\
\hline 20 & 㲔倍伸 & $\mathrm{K} 2 \mathrm{~A} 20$ & B & $\mathrm{K} 2 \mathrm{B2} 20$ & C & 87 & 78 & \\
\hline 21 & 薛弘奮 & $K 2 A 21$ & $\mathrm{D}$ & $\mathrm{K} 2 \mathrm{~B} 21$ & $\mathrm{C}$ & 80 & 74 & \\
\hline 22 & 誹宇程 & K 2 A 22 & $\mathrm{D}$ & K2B 22 & $\mathrm{C}$ & 51 & 76 & \\
\hline 23 & 㓻元鈞 & $\mathrm{K} 2 \mathrm{~A} 23$ & $\mathrm{D}$ & $\mathrm{K} 2 \mathrm{~B} 23$ & $\mathrm{C}$ & 79 & 66 & \\
\hline 24 & 陳建綸 & $\mathrm{K} 2 \mathrm{~A} 24$ & $\mathrm{D}$ & $\mathrm{K} 2 \mathrm{~B} 24$ & $\mathrm{C}$ & 69 & 74 & \\
\hline 25 & 葉中本 & $\mathrm{K} 2 \mathrm{~A} 25$ & $\bar{D}$ & $\mathrm{~K} 2 \mathrm{~B} 25$ & C & 54 & 40 & \\
\hline 26 & 唐雍焉 & K 2 A 26 & $\mathrm{D}$ & K2B 26 & $\mathrm{C}$ & 83 & 70 & \\
\hline 27 & 倪紹恩 & $\mathrm{K} 2 \mathrm{~A} 27$ & $\mathrm{D}$ & $\mathrm{K} 2 \mathrm{~B} 27$ & $D$ & 1 & 28 & \\
\hline 28 & 䔡擢凯 & $K 2 A 28$ & B & $\mathrm{K} 2 \mathrm{~B} 28$ & $\mathrm{D}$ & 90 & 72 & \\
\hline 29 & 高偉蜜 & $\mathrm{K} 2 \mathrm{~A} 29$ & $\bar{D}$ & $\mathrm{~K} 2 \mathrm{~B} 29$ & $\mathrm{D}$ & 51 & 38 & \\
\hline 30 & 謝㗐儒 & $\mathrm{K} 2 \mathrm{A3O}$ & D & $\mathrm{K} 2 \mathrm{~B} 30$ & $\mathrm{C}$ & 75 & 34 & \\
\hline 31 & 杜健瑋 & $\mathrm{K} 2 \mathrm{~A} 31$ & D & $\mathrm{K} 2 \mathrm{~B} 31$ & $\mathrm{C}$ & 63 & 28 & \\
\hline 32 & 吳品宣 & K2A 32 & $\mathrm{D}$ & $\mathrm{K} 2 \mathrm{~B} 32$ & $\mathrm{C}$ & 56 & 24 & \\
\hline 33 & 陳昭融 & $\mathrm{K} 2 \mathrm{A3} 3$ & D & $\mathrm{K} 2 \mathrm{~B} 33$ & $\mathrm{D}$ & 44 & 40 & \\
\hline 34 & 許博閞 & $\mathrm{K} 2 \mathrm{~A} 34$ & $\bar{D}$ & $\mathrm{~K} 2 \mathrm{~B} 34$ & $\mathrm{C}$ & 64 & 32 & \\
\hline 35 & 薛炳瞰 & $K 2 A 35$ & $\bar{D}$ & K2B35 & $\mathrm{C}$ & $Y$ & 22 & \\
\hline 36 & 申振 & $\mathrm{K} 2 \mathrm{~A} 36$ & D & $\mathrm{K} 2 \mathrm{~B} 36$ & $\mathrm{C}$ & 71 & 12 & \\
\hline 37 & 黃権儀 & $\mathrm{K} 2 \mathrm{~A} 37$ & $\mathrm{D}$ & $\mathrm{K} 2 \mathrm{~B} 37$ & D & 53 & 36 & \\
\hline 38 & 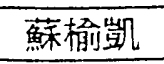 & $\mathrm{K} 2 \mathrm{~A} 38$ & $\bar{D}$ & $\mathrm{~K} 2 \mathrm{~B} 38$ & $\mathrm{D}$ & 64 & 8 & \\
\hline 39 & 侯仲発 & $K 2 A 39$ & D & $\mathrm{K} 2 \mathrm{~B} 39$ & $\mathrm{C}$ & 77 & 18 & \\
\hline 40 & 䓫了明維 & $\mathrm{K} 2 \mathrm{~A} 40$ & D & $\mathrm{K} 2 \mathrm{~B} 40$ & C & 95 & 44 & \\
\hline 41 & 林芳慈 & $\mathrm{K} 2 \mathrm{~A} 41$ & $\mathrm{D}$ & $\mathrm{K} 2 \mathrm{~B} 41$ & $\mathrm{C}$ & 71 & 30 & \\
\hline 12 & 陳㭆国 & $k 2 \wedge 42$ & $D$ & $\mathrm{~K} 2 \mathrm{~B} 42$ & $C$ & 66 & 32 & \\
\hline
\end{tabular}




\begin{tabular}{|c|c|c|c|c|c|c|c|c|}
\hline$: \because n$ & $\ldots \ldots \ldots$ & 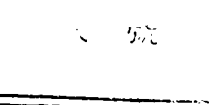 & $\begin{array}{c}\text { pre.h.s } \\
\text { seonec }\end{array}$ & $\therefore$ 然 & $\begin{array}{c}\text { pus.4.s. } \\
s(1) \cdots 6 \\
\end{array}$ & $\begin{array}{l}\text { conolion } \\
\text { scourc }\end{array}$ & huchlate & $i w i a !$ \\
\hline 1 & $\because \quad \therefore$ & $111 \therefore 01$ & 1) & $M 1 \mathrm{~B} O 1$ & C & 37 & 10 & \\
\hline 2 & 少少星 & M1 $\triangle 02$ & 1) & $M 1 \mathrm{BO}$ & i) & 61 & 28 & \\
\hline 3 & 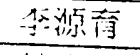 & $M 1 \wedge 03$ & D) & $M 1 B 03$ & $C$ & 79 & 31 & \\
\hline 4 & 梦志傩 & $M 1 \mathrm{AO4}$ & D & $M] B O 4$ & $\mathrm{C}$ & 65 & 28 & \\
\hline 5 & 酏整欽 & $M 1 \mathrm{AO} 5$ & $\mathrm{C}$ & $M 1 B 05$ & $C$ & 50 & 38 & \\
\hline 6 & 洪交財 & $M 1 A 06$ & D & $M 1 B 06$ & D & 58 & 12 & \\
\hline 7 & 隹振方 & M]AOT & D & $M 1 B 07$ & C & 69 & 1 & \\
\hline 8 & 張家焉 & $M] A 08$ & D) & $\mathrm{M}] \mathrm{BO} 8$ & $C$ & 67 & 68 & \\
\hline 9 & 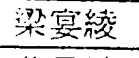 & $M 1 \wedge 09$ & D) & $M 1 B 09$ & $\mathrm{C}$ & 72 & 16 & \\
\hline 10 & 莊丞坤 & $M 1 \mathrm{~A} 10$ & $D$ & $\mathrm{M} 1 \mathrm{~B}] \mathrm{O}$ & $\mathrm{C}$ & 67 & 22 & \\
\hline 11 & 陣明彣 & $M 1 A 11$ & D & M1B 11 & C & 81 & 18 & \\
\hline 12 & 陳智裹 & $M 1 A] 2$ & $D$ & $M 1 B 12$ & C & 61 & 34 & \\
\hline 13 & 陳福智 & $M 1 A 13$ & D & $M 1 B 13$ & $\mathrm{C}$ & 74 & 18 & \\
\hline 14 & 筫建交 & MIA 14 & D & $M 1 B] 4$ & D & 73 & 20 & \\
\hline 15 & 黃健隹 & $M 1 \mathrm{~A} 15$ & D & $M 1 B 15$ & C & 73 & 14 & \\
\hline 16 & 黄管榮 & $M 1 A 16$ & D & $M 1 B 16$ & $\mathrm{C}$ & 43 & 24 & \\
\hline 17 & 劉大僥 & MIAI 1 & D & $M 1 B \perp 7$ & $\mathrm{C}$ & 75 & 24 & \\
\hline 18 & 謝聰民 & $M 1 A 18$ & D & $M 1 B 18$ & $\mathrm{C}$ & 73 & 22 & \\
\hline 19 & 蘇信在 & $M 1 A 19$ & D & $M 1 B 19$ & $\mathrm{C}$ & 79 & 26 & \\
\hline 20 & 蘇俊生 & $M 1.120$ & D & $\mathrm{MIB} 20$ & $\mathrm{C}$ & 65 & 40 & \\
\hline 21 & 方婷瑢 & M1A21 & D & $M 1 B 21$ & $C$ & 60 & 21 & \\
\hline 22 & 王黛陸 & $M 1 \mathrm{~A} 22$ & C & M1B 22 & $C$ & 46 & 22 & \\
\hline 23 & 哭幸虹 & $M 1 \mathrm{~A} 23$ & D & $M 1 B 23$ & D & & 1 & \\
\hline 24 & 谷怡菸 & $\mathrm{M} 1 \mathrm{~A} 24$ & D & M 1 B 24 & C & 78 & 28 & \\
\hline 25 & 器婉儀 & MIA 25 & D & $M 1 B 25$ & $\mathrm{C}$ & & 1 & \\
\hline 26 & 沈嘉雯 & $M 1 A 26$ & D & M1B 26 & $C$ & 35 & 10 & \\
\hline 27 & 林俐君 & $M 1 \mathrm{~A} 27$ & $C$ & $M 1 B 27$ & $C$ & 59 & 34 & \\
\hline 28 & 亦不静君 & $M 1 A 28$ & D & $M 1 B 28$ & $C$ & 75 & 50 & \\
\hline 29 & 洪顷婷 & M1A 29 & D & M1B29 & C & 72 & 18 & \\
\hline 30 & 洪智卿 & $M 1430$ & D) & M1B 30 & $C$ & 80 & 26 & \\
\hline 31 & 洪智華 & MIA3I & D & M1B.31 & D) & 66 & 28 & \\
\hline 32 & 張䨪心 & M1A 32 & 1) & M] B 32 & $D$ & 85 & 28 & \\
\hline 33 & 梁三瑨 & $M 1$ A 33 & 1) & $M 1 B 33$ & $C$ & 51 & 36 & \\
\hline 34 & 梁美珆 & MIA 34 & $D$ & $M 1 B 34$ & $C$ & 79 & 12 & \\
\hline 35 & 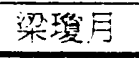 & M1A35 & D) & MIB 35 & C & 74 & 10 & \\
\hline 36 & 許理之 & M1 $A 36$ & D & $M 1 B 36$ & $C$ & 39 & 14 & \\
\hline 37 & 陳龺伶 & M1A37 & D) & $M 1 B 37$ & $C$ & 82 & 50 & \\
\hline 38 & 萝㘬萑華 & $M 1 A 38$ & D & $M 1 B 38$ & $C$ & 55 & 18 & \\
\hline 39 & 䍒釭婷 & M1A39 & $D$ & M1 B 39 & $C$ & 68 & 68 & \\
\hline 40 & 黃交慧 & $\mathrm{M} 1 \mathrm{A40}$ & $D$ & $\mathrm{MIB} 40$ & $C$ & 87 & 46 & \\
\hline 41 & 茠橖慧 & $M 1 A 41$ & D & $\mathrm{M} 1 \mathrm{~B} 4 \mathrm{I}$ & C & 72 & 38 & \\
\hline 42 & 黃鈺婷 & M]A42 & D & $M \perp B A 2$ & $\mathrm{C}$ & 75 & 16 & \\
\hline 43 & 祭宣娟 & $M] \wedge 43$ & D & $M 1 B 43$ & $\mathrm{C}$ & 86 & 34 & \\
\hline 44 & 塸次诒浔 & $\mathrm{M} 1 \mathrm{~A} 4 \mathrm{~A}$ & 1) & $M] \wedge 44$ & $\mathrm{C}$ & & 24 & \\
\hline
\end{tabular}




\begin{tabular}{|c|c|c|c|c|c|c|c|c|}
\hline :o. & '....m & $\therefore \quad \%$ & 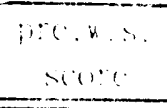 & $\therefore: t$ & $\begin{array}{l}\text { iks.u.s. } \\
\text { scoise }\end{array}$ & $\begin{array}{l}\text { cmisison } \\
\text { scome }\end{array}$ & helokicus & bia: \\
\hline 1 & 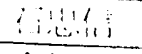 & M2AO1 & 1) & $M 2 B O 1$ & [) & 60 & 1 & \\
\hline 2 & 方惟侣 & $M 2 \wedge 02$ & 1) & $M 2 B O 2$ & C & 66 & 18 & \\
\hline 3 & 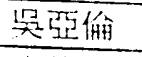 & $M 2 \wedge 03$ & $\mathrm{C}$ & $M 2 B 03$ & C & 72 & 44 & \\
\hline 4 & 李俊僮 & $M 2 \wedge 04$ & I) & $\mathrm{M} 2 \mathrm{BO}$ & I) & 60 & 22 & \\
\hline 5 & 周聖唓 & $M 2 \wedge 05$ & D) & M2BO5 & ]) & 44 & 18 & \\
\hline 6 & 氾忠誠 & M2^06 & 1) & M 2 B 06 & $\mathrm{C}$ & & $i$ & \\
\hline 7 & 梁炘鈺 & M2A0T & D) & $\mathrm{M} 2 \mathrm{BO}$ & 1) & 65 & 34 & \\
\hline 8 & 許建杽 & $M 2 A 08$ & D) & $\mathrm{M} 2 \mathrm{BO} 8$ & C & 55 & 22 & \\
\hline 9 & 許智淵 & M2A09 & C & $\mathrm{M} 2 \mathrm{BO} 9$ & $C$ & 64 & 28 & \\
\hline 10 & 陳旺磷 & M2A] & $\mathrm{D}$ & $\mathrm{M} 2 \mathrm{B10}$ & $\mathrm{C}$ & 31 & 14 & \\
\hline 11 & 鄋建生 & $M 2 A 11$ & D & $\mathrm{M} 2 \mathrm{~B} 1 \mathrm{~J}$ & $D$ & 47 & 10 & \\
\hline 12 & 陳逸帆 & $M 2 A 12$ & D & $M 2 B 12$ & $\mathrm{C}$ & 59 & 26 & \\
\hline 13 & 陸俊考 & $M 2 A 13$ & D & $M 2 B 13$ & $\mathrm{C}$ & 62 & 38 & \\
\hline 14 & 黄敬中 & $M 2 A 14$ & D & M2B 14 & D & 58 & 8 & \\
\hline 15 & 黃道战粦 & M2A 15 & D & M2B 15 & D & 76 & 26 & \\
\hline 16 & 劉俊佶 & $M 2 A 16$ & D & M2B 16 & D & 60 & 10 & \\
\hline 17 & 察混宏 & $M 2 A 17$ & $\mathrm{C}$ & M2B17 & $\mathrm{C}$ & 78 & 32 & \\
\hline 18 & 鄭智豪 & $M 2 A 18$ & D & M2B 18 & $C$ & 75 & 1 & \\
\hline 19 & 盧俊宏 & $M 2 A 19$ & D & $M 2 B 19$ & D & 75 & 38 & \\
\hline 20 & 賴伸瑋 & M2220 & $!$ & $\mathrm{M} 2 \mathrm{B2} 0$ & $\mathrm{C}$ & & i & \\
\hline 21 & 王壹珊 & $M 2 A 21$ & $B$ & M2B 21 & $\mathrm{C}$ & 44 & 28 & \\
\hline 22 & 利曉雯 & M2A 22 & $D$ & M2B 22 & $C$ & 48 & 1 & \\
\hline 23 & 奂小琪 & $M 2 A 23$ & B & M2B 23 & $\mathrm{C}$ & 65 & 42 & \\
\hline 24 & 丧映瑤 & M2A 24 & D & M2B 24 & D & 94 & 32 & \\
\hline 25 & 策怡君 & M2A 25 & C & $112 \mathrm{~B} 25$ & 1 & 47 & 38 & \\
\hline 26 & 李艾倫 & $\mathrm{M} 2 \mathrm{~A} 26$ & D & M2B 26 & C & 86 & 22 & \\
\hline 27 & 林美惠 & M2A 27 & D & M2B 27 & D & 77 & 14 & \\
\hline 28 & 邱莉敉 & M2A 28 & B & $M 2 B 28$ & $\mathrm{C}$ & 72 & 34 & \\
\hline 29 & 張雅婷 & M2A29 & $\mathrm{C}$ & $M 2 B 29$ & $C$ & 68 & 30 & \\
\hline 30 & 梁叔慧 & $M 2 A 30$ & $\mathrm{C}$ & Ni2B 30 & $\mathrm{C}$ & 73 & 52 & \\
\hline 31 & 梁逸瑋 & M2A 31 & 1) & M2B3I & C & 70 & 24 & \\
\hline 32 & 梁雅婷 & M2A 32 & C & M2B32 & C & 75 & 28 & \\
\hline 33 & 梁媛純 & M2A 33 & $C$ & $\mathrm{M} 2 \mathrm{~B} 33$ & B & 42 & 28 & \\
\hline 34 & 室乃珊足 & M2A34 & C & $M 2 B 3 A$ & $\mathrm{C}$ & 49 & 44 & \\
\hline 35 & 陳姿秀 & M2A35 & $D$ & $M 2 B 35$ & C & 83 & 52 & \\
\hline 36 & 陷慧如 & $M 2 \wedge 36$ & D) & M2B 36 & B & 45 & 16 & \\
\hline 37 & 堇美恵 & $M 2 A 37$ & D & M2B37 & $B$ & 69. & 18 & \\
\hline 38 & 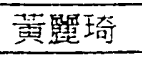 & M2A38 & D) & M2B 38 & C & 67 & 44 & \\
\hline 39 & 翏淑娟 & $M 2 A 39$ & D & M2B 39 & $\mathrm{C}$ & 85 & 28 & \\
\hline 40 & 熊歌香 & $\mathrm{M} 2 \mathrm{~A} 40$ & D) & $\mathrm{M} 2 \mathrm{~B} 40$ & $\mathrm{C}$ & 62 & 14 & \\
\hline 41 & 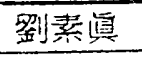 & $\mathrm{M} 2 \mathrm{A1}$ & D) & $\mathrm{M} 2 \mathrm{~B} 41$ & $\mathrm{C}$ & 78 & 26 & \\
\hline 42 & 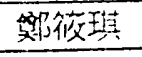 & $M 2 A 42$ & 1) & M2BA2 & C & $68 \therefore$ & 14 & \\
\hline 43 & 陳佁心 & $M 2 A 13$ & D & $M 2 A 43$ & $\mathrm{C}$ & 70 & 10 & \\
\hline 44 & 真承㑷 & $\mathrm{M} 2 \mathrm{A4} 4$ & $D$ & $M 2 A \wedge 1$ & $\mathrm{C}$ & 87 & 52 & \\
\hline
\end{tabular}




\begin{tabular}{|c|c|c|c|c|c|c|c|c|}
\hline no. & $: 1, \ldots \ldots$ & & $\begin{array}{c}\text { 1.re.u.s. } \\
\text { …uns }\end{array}$ & (1) & $\begin{array}{l}\text { pos.k.s. } \\
\text { secose }\end{array}$ & $\begin{array}{c}\text { cmolion } \\
\text { seoro }\end{array}$ & kikulcdse & $101: 1$ \\
\hline 1 & 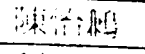 & 11101 & $n$ & $E 1 B O 1$ & Bi & 68 & 46 & \\
\hline 2 & 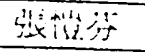 & $1 \leq 1 \wedge 02$ & 1) & $E 1 B 02$ & C & 54 & 36 & \\
\hline 3 & 䌽宜茥 & $E 1 \wedge 03$ & D & E $1 B 03$ & $\mathrm{C}$ & 38 & 46 & \\
\hline 4 & 翁千琇 & E $1 \wedge 01$ & $\mathrm{D}$ & E $1 B 04$ & $\mathrm{C}$ & 71 & 58 & \\
\hline 5 & 白括箈 & $E 1 \wedge 05$ & $D$ & E1BO5 & $\mathrm{C}$ & 73 & 48 & \\
\hline 6 & 萝诒杽 & $E 1 \wedge 06$ & D & E1BO6 & C & 85 & 26 & \\
\hline 7 & 士雅如 & E1 107 & $\mathrm{C}$ & $E 1 B 07$ & $\mathrm{C}$ & 74 & 11 & \\
\hline 8 & 到青㶳 & E1A08 & D & E1BO & C & 55 & 32 & \\
\hline 9 & 洪慧敏 & E1A09 & D & E1BO9 & $\mathrm{C}$ & 50 & 44 & \\
\hline 10 & 蔡欣諭 & E $1 A 10$ & $D$ & E $1 B 10$ & $C$ & 58 & 34 & \\
\hline 11 & 王明乼 & E1A11 & D & $E 1 B 11$ & $B$ & 75 & 36 & \\
\hline 12 & 呉欣茹 & E $1 \mathrm{~A} 12$ & D & E $1 B 12$ & $\mathrm{D}$ & 47 & 58 & \\
\hline 13 & 兽有純 & E 1 A 13 & $\mathrm{C}$ & $E 1 B 13$ & $\mathrm{D}$ & 76 & 10 & \\
\hline 14 & 陳月汝 & E 1 A 14 & $D$ & E 1 B 14 & $\mathrm{D}$ & 67 & 24 & \\
\hline 15 & 李巧文 & E1A15 & 1 & $E 1 B 15$ & D & 77 & 0 & \\
\hline 16 & 林怡至 & E 1 A 16 & D & $E 1 B 16$ & $D$ & 49 & 52 & \\
\hline 17 & 涱筱璇 & $E 1 A 17$ & $D$ & $E 1 B 17$ & D & 84 & 68 & \\
\hline 18 & 李美君 & $E 1 A 18$ & $D$ & $E 1 B 18$ & $D$ & 69 & 12 & \\
\hline 19 & 策蹺㯖 & $E 1 A 19$ & D & E1B 19 & $\mathrm{D}$ & 52 & 24 & \\
\hline 20 & 骓敏貞 & $E 1 A 20$ & D & E1B20 & $D$ & 71 & 44 & \\
\hline 21 & 呉松箖 & $E 1 A 21$ & $\mathrm{C}$ & E 1 B 2 1 & $B$ & 81 & 20 & \\
\hline 22 & 劉育榓 & $E 1$ A 22 & D & E 1 B 22 & $\mathrm{C}$ & 73 & 44 & \\
\hline 23 & 倅芳義 & E1A23 & D & E1B23 & $C$ & 75 & 40 & \\
\hline 24 & 到品亚 & E1A24 & $D$ & E1B 24 & $D$ & 31 & 34 & \\
\hline 25 & 張忠維 & $E 1 A 25$ & D & E1B 25 & $\mathrm{C}$ & 55 & 32 & \\
\hline 26 & 劉昌榮 & E 1 A 26 & D & E $1 B 26$ & D & 78 & 1 & \\
\hline 27 & 何其泰 & E1A27 & D & E $1 B 27$ & $\mathrm{D}$ & 68 & 46 & \\
\hline 28 & 張哲豪 & E1A28 & D & E1B 28 & C & 88 & 36 & \\
\hline 29 & 三交正 & $E] A 29$ & $D$ & E1B29 & C & 51 & 4 & \\
\hline 30 & 蔡正智 & E1A30 & $\mathrm{D}$ & E 1 B 30 & $\mathrm{D}$ & 63 & 52 & \\
\hline 31 & 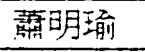 & E1A31 & D & E 1 B 31 & $\mathrm{C}$ & 80 & 60 & \\
\hline 32 & 漂志偉 & E 1 A 32 & D & E 1 B 32 & C & 85 & 34 & \\
\hline 33 & 㴆貴凱 & E1A33 & $D$ & E1B 33 & $D$ & 78 & 24 & \\
\hline 34 & 三丞童 & E1A34 & $D$ & E 1 B 34 & D & 54 & 10 & \\
\hline 35 & 妙建交 & E1A35 & D & E1B35 & $\mathrm{C}$ & 67 & 24 & \\
\hline 36 & 婒正县 & $E 1$ A 36 & D & E1B 36 & $C$ & 61 & 18 & \\
\hline 37 & 潘念 & E1A37 & D & $E 1 B 37$ & $B$ & $6 i$ & 8 & \\
\hline 38 & 部錦省 & $E 1 A 38$ & D & E1B 38 & C & 69 & 12 & \\
\hline 39 & 棵昆韓 & $E 1 A 39$ & D & E1B39 & $C$ & 53 & 46 & \\
\hline 40 & 傅國榮 & $E 1 A 40$ & $\mathrm{C}$ & E $1 B 40$ & $\mathrm{D}$ & 61 & 8 & \\
\hline 41 & 王韋評 & E $1 A 41$ & D & E 1B 41 & $D$ & 71 & 22 & \\
\hline 42 & 賴宸湋 & E $1 A 42$ & $C$ & E1B 42 & $-\mathrm{C}$ & 74 & 30 & \\
\hline 43 & 徐裕翔 & E1A 43 & D & E 1 B 43 & $C$ & 52 & 38 & \\
\hline 44 & 社佳静 & E $1 \mathrm{~A} 44$ & $\mathrm{D}$ & E1B 44 & $C$ & 53 & 38 & \\
\hline 45 & 羅小偷 & $E \perp A 45$ & $D$ & $E 1 B 45$ & C & 45 & 36 & \\
\hline
\end{tabular}




\begin{tabular}{|c|c|c|c|c|c|c|c|c|}
\hline no. & & & $\begin{array}{l}c \overline{w . s .} \\
\text { acio.c. }\end{array}$ & 代 洸 & 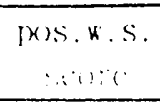 & $\begin{array}{l}\text { cmolion } \\
\text { scourt }\end{array}$ & knowledge & lolit \\
\hline 1 & Sil & 12101 & i) & $52 B 01$ & $i$ & 81 & 30 & \\
\hline 2 & 剔这純 & $E 2 \wedge 02$ & D) & E2B02 & D) & 78 & 10 & \\
\hline 3 & 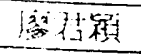 & $52 \wedge 03$ & $D$ & $\mathrm{E} 2 \mathrm{BO} 3$ & D) & 86 & 34 & \\
\hline 4 & 林筩壦 & $E 2 \wedge 01$ & $D$ & $E 2 B 04$ & $\Lambda$ & 84 & 22 & \\
\hline 5 & 眞怡貞 & E2A05 & D & $\mathrm{E} 2 \mathrm{BO} 5$ & D) & 51 & 34 & \\
\hline 6 & 陠怡沼 & $E 2 A 06$ & $D$ & E2B 06 & $D$ & 86 & 16 & \\
\hline 7 & 圈美玲 & $E 2 A 07$ & $\mathrm{D}$ & E 2 B 07 & $C$ & 84 & 46 & \\
\hline 8 & 称椒憶 & $\mathrm{E} 2 \mathrm{A0} 8$ & $D$ & E 2 B 08 & $D$ & 81 & 18 & \\
\hline 9 & 陳宣君 & $\mathrm{E} 2 \mathrm{AO} 9$ & $D$ & E2B09 & D & 91 & 32 & \\
\hline 10 & 張玉慧 & $E 2 A 10$ & D & $\mathrm{E} 2 \mathrm{~B} 10$ & C & 58 & 32 & \\
\hline 11 & 陳怡伶 & E2A11 & $D$ & E 2B 1 1 & $\bar{C}$ & 83 & 24 & \\
\hline 12 & 彭雅鈴 & $E 2 A 12$ & D & $E 2 B 12$ & $\mathrm{C}$ & 84 & 10 & \\
\hline 13 & 林盈如 & $E 2 A 13$ & $\mathrm{D}$ & E 2 B 13 & $A$ & 65 & 16 & \\
\hline 14 & 陳怡利 & E2A14 & $D$ & E 2B 1 4 & D & 90 & 22 & \\
\hline 15 & 林巧芳 & $\mathrm{E} 2 \mathrm{~A} 15$ & D & E 2 B 15 & $D$ & 56 & 10 & \\
\hline 16 & 楊怡珊 & E 2 A 16 & D & E 2 B 16 & C & 78 & 28 & \\
\hline 17 & 嘍辛䝁 & $E 2 \mathrm{~A} 17$ & $D$ & $\mathrm{E} 2 \mathrm{~B} 17$ & $B$ & 70 & 10 & \\
\hline 18 & 踤淑娟 & $E 2 A 18$ & $C$ & $E 2 B 18$ & $B$ & 89 & 16 & \\
\hline 19 & 勀容湘 & $E 2 A 19$ & D & E 2 B 19 & D & 68 & 14 & \\
\hline 20 & 填冠吟 & $E 2 \mathrm{~A} 20$ & $B$ & $E 2$ B 20 & $C$ & 70 & 1 & \\
\hline 21 & 莊宗民 & E2A 21 & $B$ & $E 2 B 21$ & C & 91 & 18 & \\
\hline 22 & 林建志 & E2A22 & $D$ & E 2 B 22 & $D$ & 54 & 28 & \\
\hline 23 & 李宗展 & $E 2 A 23$ & $D$ & E 2 B 23 & $D$ & 94 & 28 & \\
\hline 24 & 林偉政 & $E 2 A 24$ & $\mathrm{C}$ & $E 2 B 24$ & $D$ & 67 & 30 & \\
\hline 25 & 楊仁傑 & E 2A 25 & $D$ & E 2B25 & $D$ & 87 & 48 & \\
\hline 26 & 黃逸仁 & $E 2 A 26$ & D & E 2 B 26 & $D$ & 83 & i & \\
\hline 27 & 廖偉谷 & E2A27 & D & E 2 B 27 & $B$ & 67 & 32 & \\
\hline 28 & 楊凱鍵 & E2A28 & D & E 2 B 28 & D & 63 & 26 & \\
\hline 29 & 羅聖交 & $E 2 A 29$ & $D$ & E 2 B 29 & D & 92 & 28 & \\
\hline 30 & 陳宗義 & E2A30 & D & $E 2 B 30$ & $C$ & 70 & 28 & \\
\hline 31 & 卓明韻 & E2A31 & $D$ & E2B31 & $D$ & 60 & 10 & \\
\hline 32 & 與建隆 & $E 2 \mathrm{~A} 32$ & $D$ & $E 2 B 32$ & D & 70 & 18 & \\
\hline 33 & 洪呁琮 & E2A33 & D & E2B33 & $D$ & 63 & 10 & \\
\hline 34 & 嚴䇥媇 & E2A34 & 1 & E $2 B 34$ & 1 & & 1 & \\
\hline 35 & 羅志偉 & E2A35 & $B$ & $E 2 B 35$ & D & 74 & 14 & \\
\hline 36 & 江佳安 & $E 2 A 36$ & $D$ & $E 2 B 36$ & $C$ & 72 & 12 & \\
\hline 37 & 劉育帆 & E 2 A 37 & $D$ & E 2 B 37 & $D$ & 83 & 1 & \\
\hline 38 & 朱偉仁 & E2A38 & 1 & E 2B38 & 1 & $\therefore$ & $!$ & \\
\hline 39 & 林霞实 & E2A39 & $D$ & E 2B39 & $D$ & 76 & 8 & \\
\hline 40 & 陳㐙國 & $\mathrm{E} 2 \mathrm{A4} 0$ & $\mathrm{D}$ & $E 2 B 40$ & $C$ & 56 & 2 & \\
\hline 41 & 邴建賓 & E2A41 & D & $E 2 B 41$ & $D$ & 58 & 12 & \\
\hline 42 & 䫓明昇 & $E 2 A 42$ & D & E2B 4? & $C$ & 47 & 2 & \\
\hline 43 & 賴韋筓 & E 2 A 43 & $D$ & E2B43 & $D$ & 36 & 10 & \\
\hline 44 & 許順翔 & E $2 A 44$ & $D$ & E2B 44 & $C$ & 35 & 22 & \\
\hline 45 & 鳥硻魚 & $E 2 A 45$ & $D$ & E2B45 & D & 44 & 12 & \\
\hline 46 & 黄復猿 & E2A 16 & D & $E 2546$ & D & 51 & 30 & \\
\hline 47 & 朱富權 & E2A 47 & D & $E 2 \wedge 47$ & $\mathrm{C}$ & 59 & 36 & \\
\hline
\end{tabular}


APPENDIX G:

THE WORKS OF STUDENTS 
APPENDIX G: The Works of Sudents

"Poor" Ratings
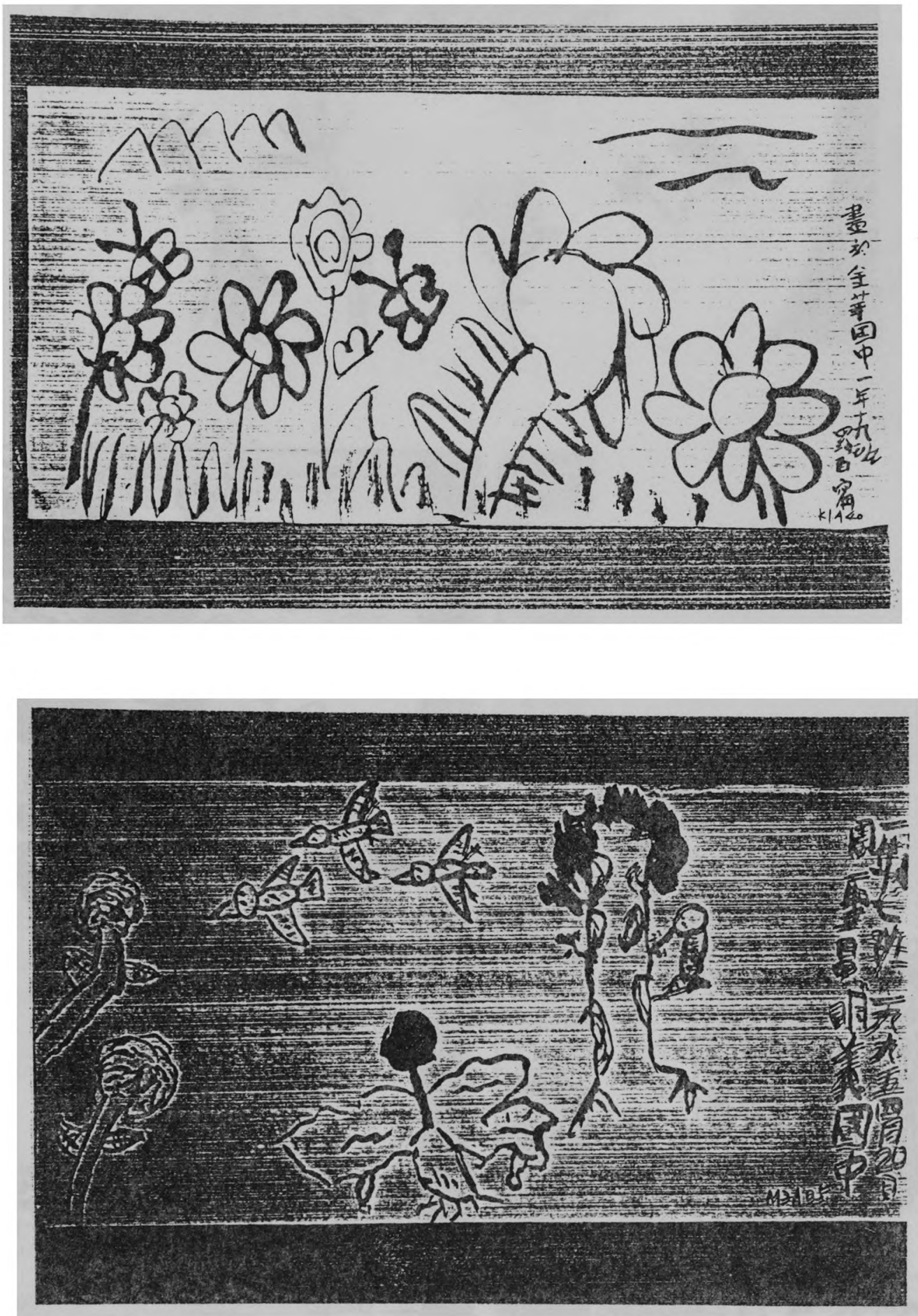


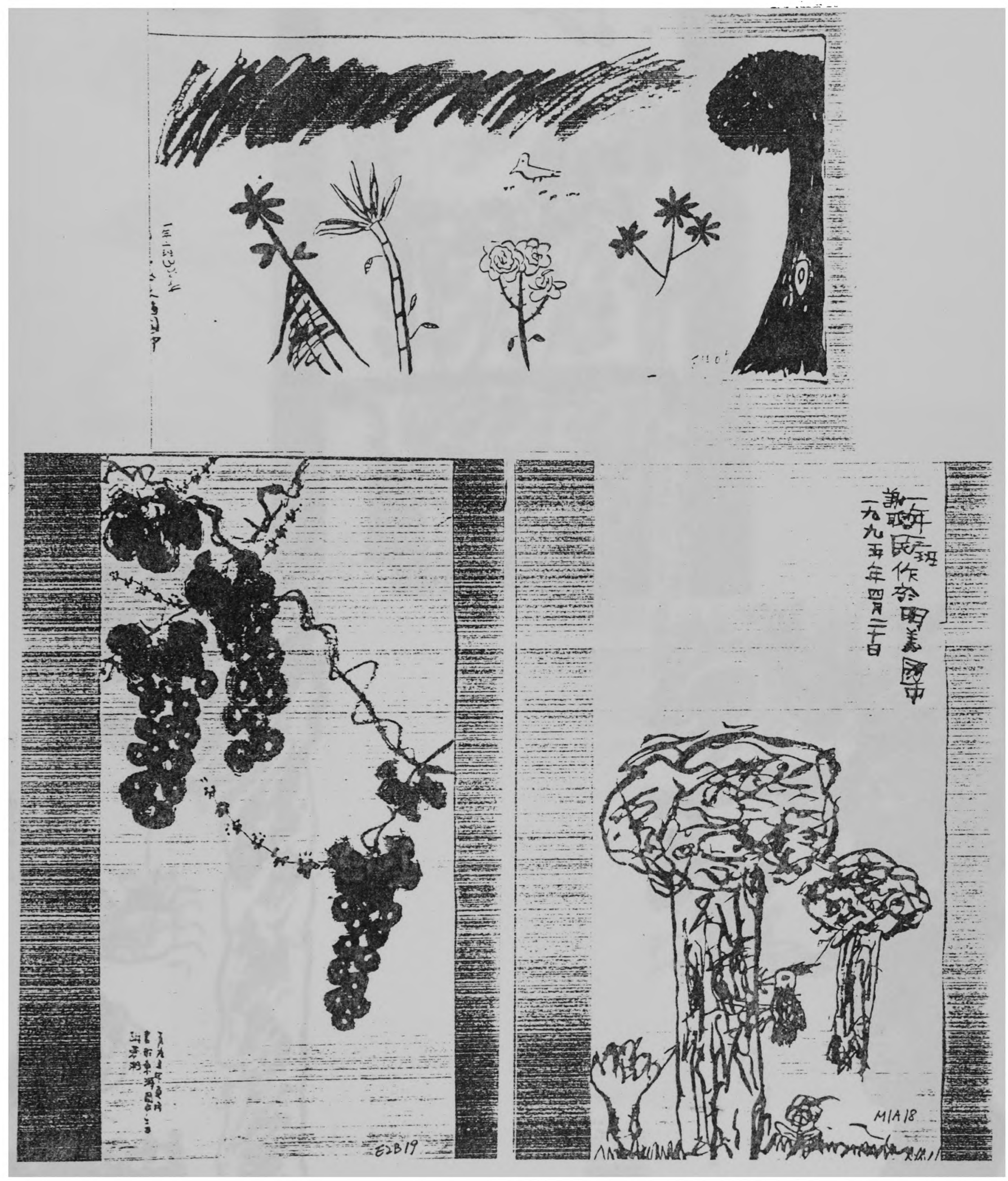




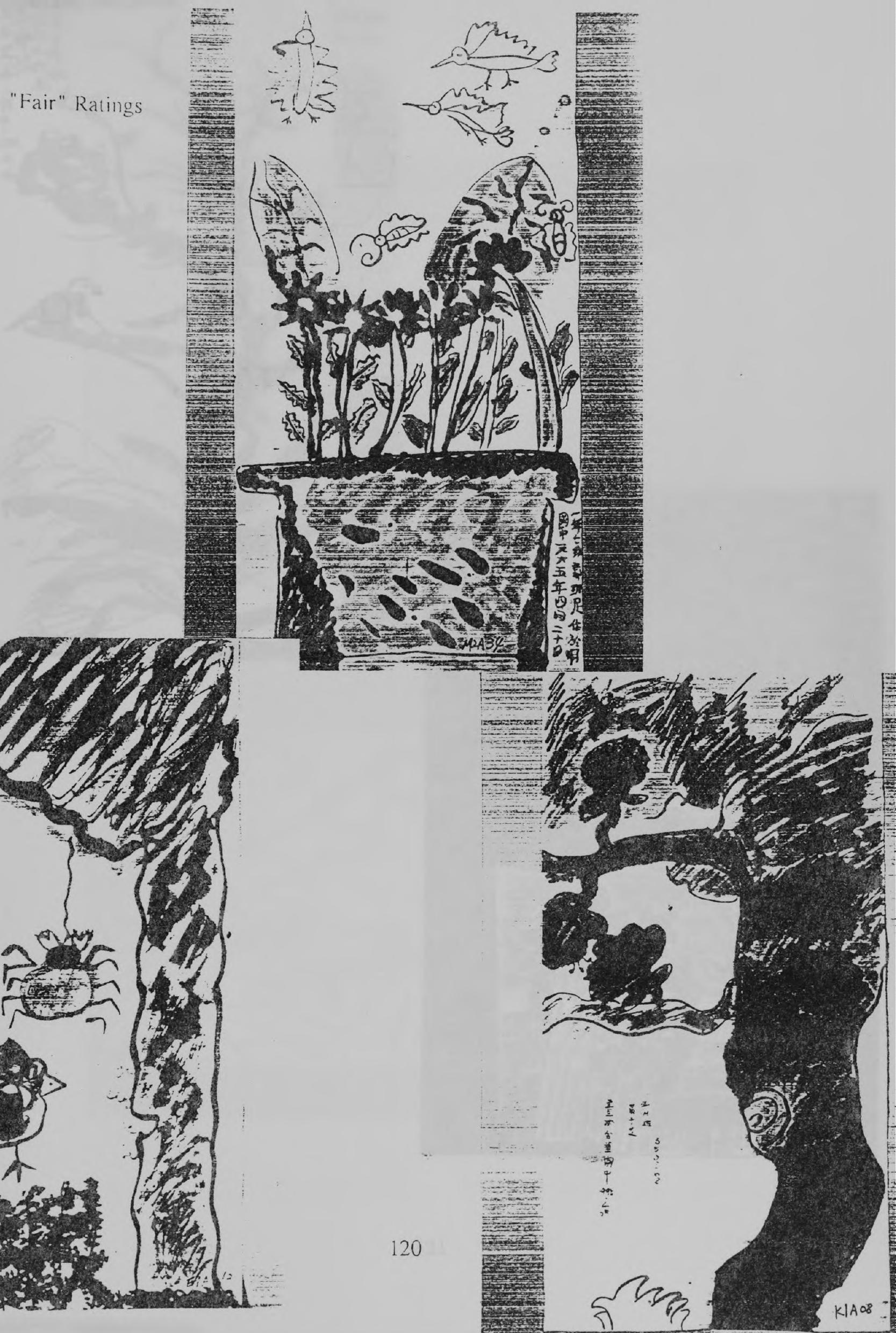



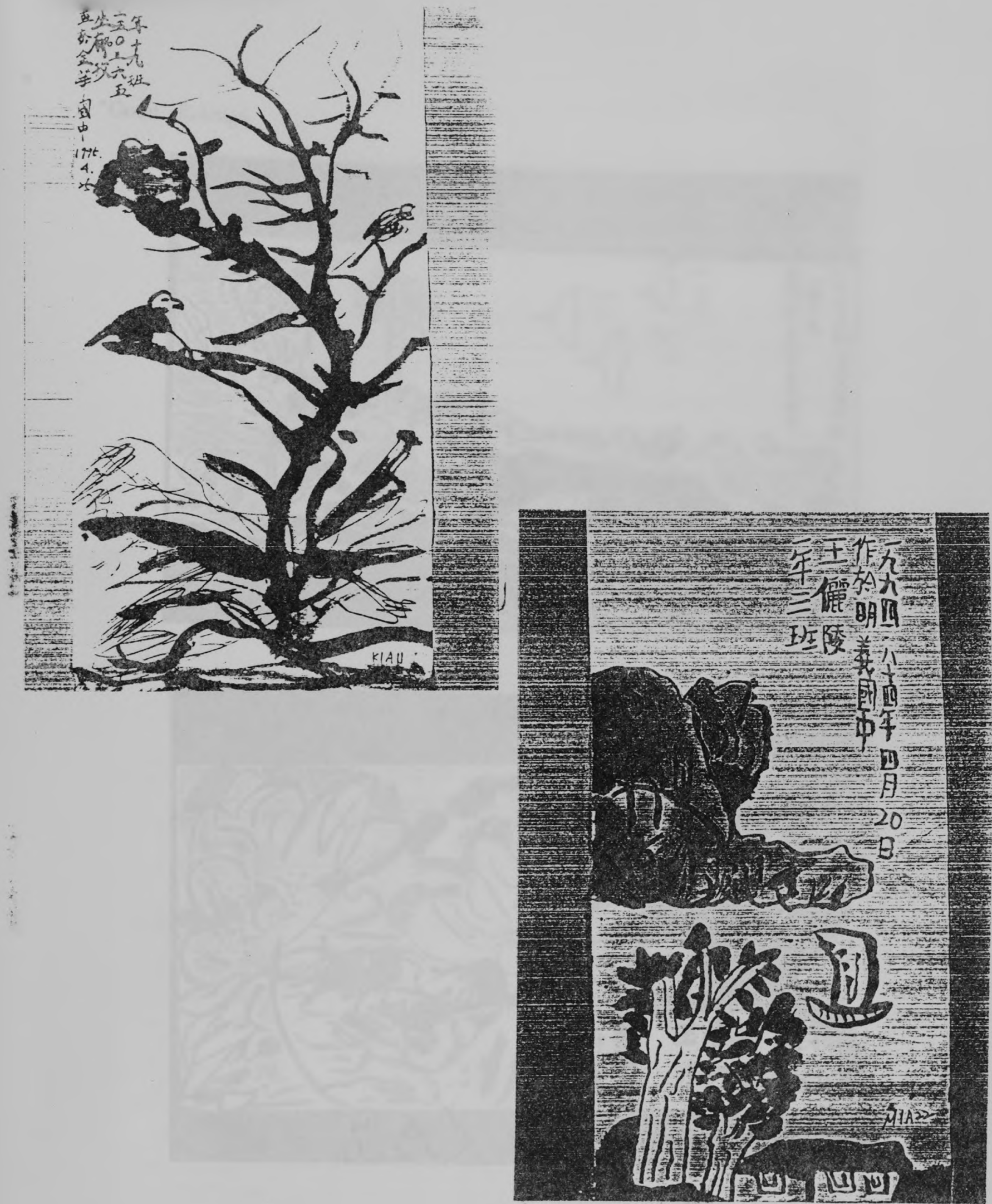
"Good" Ratings
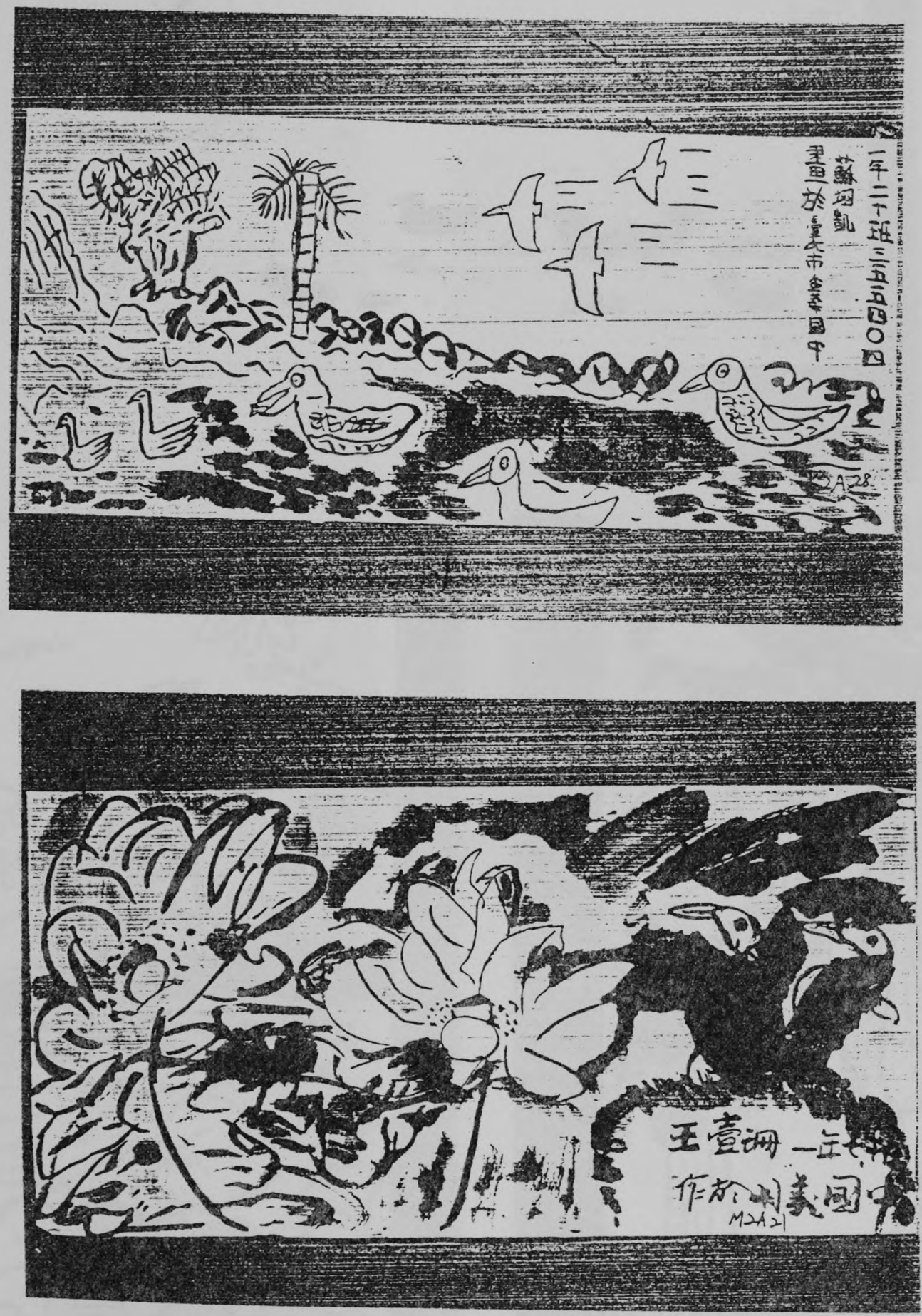

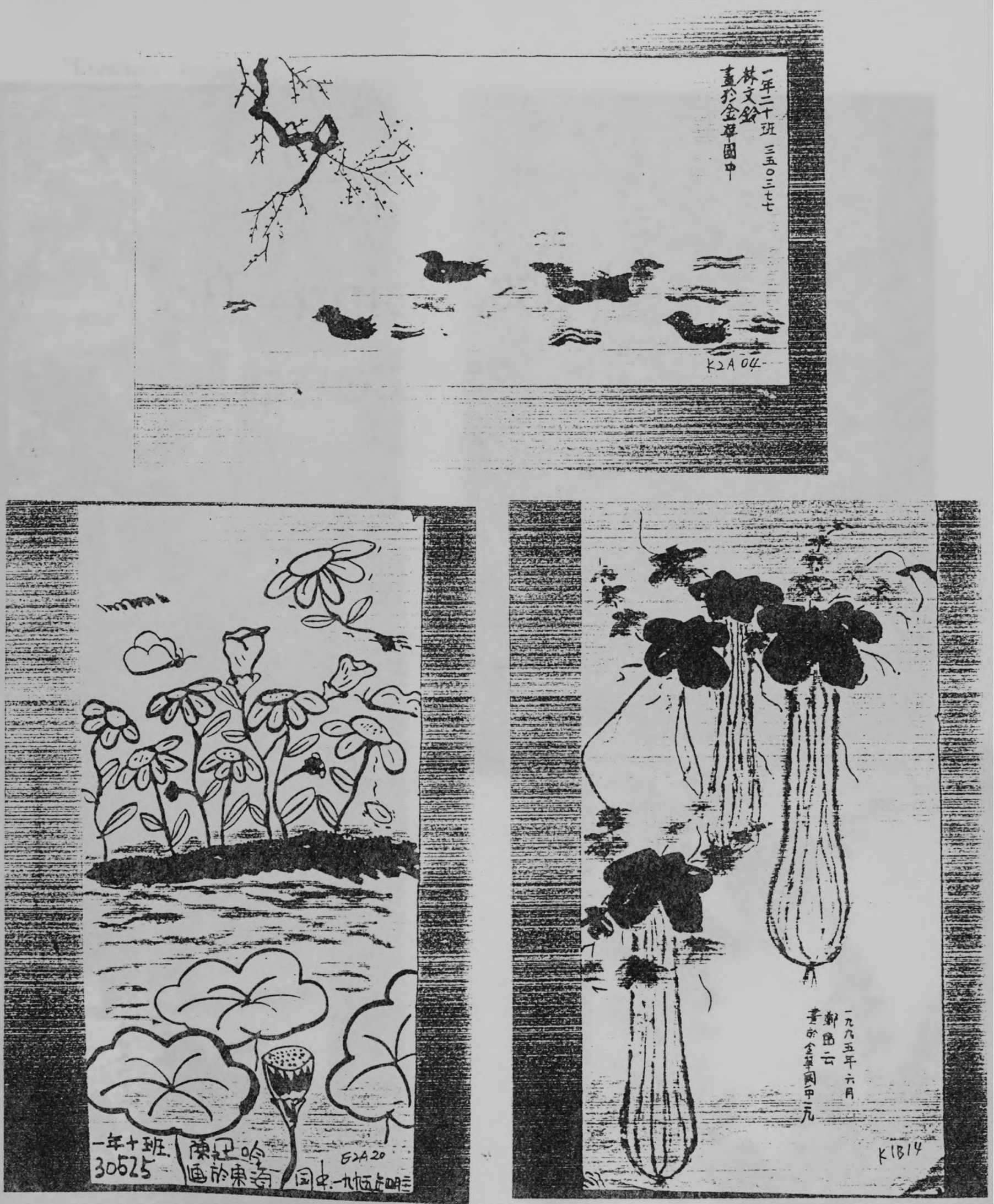

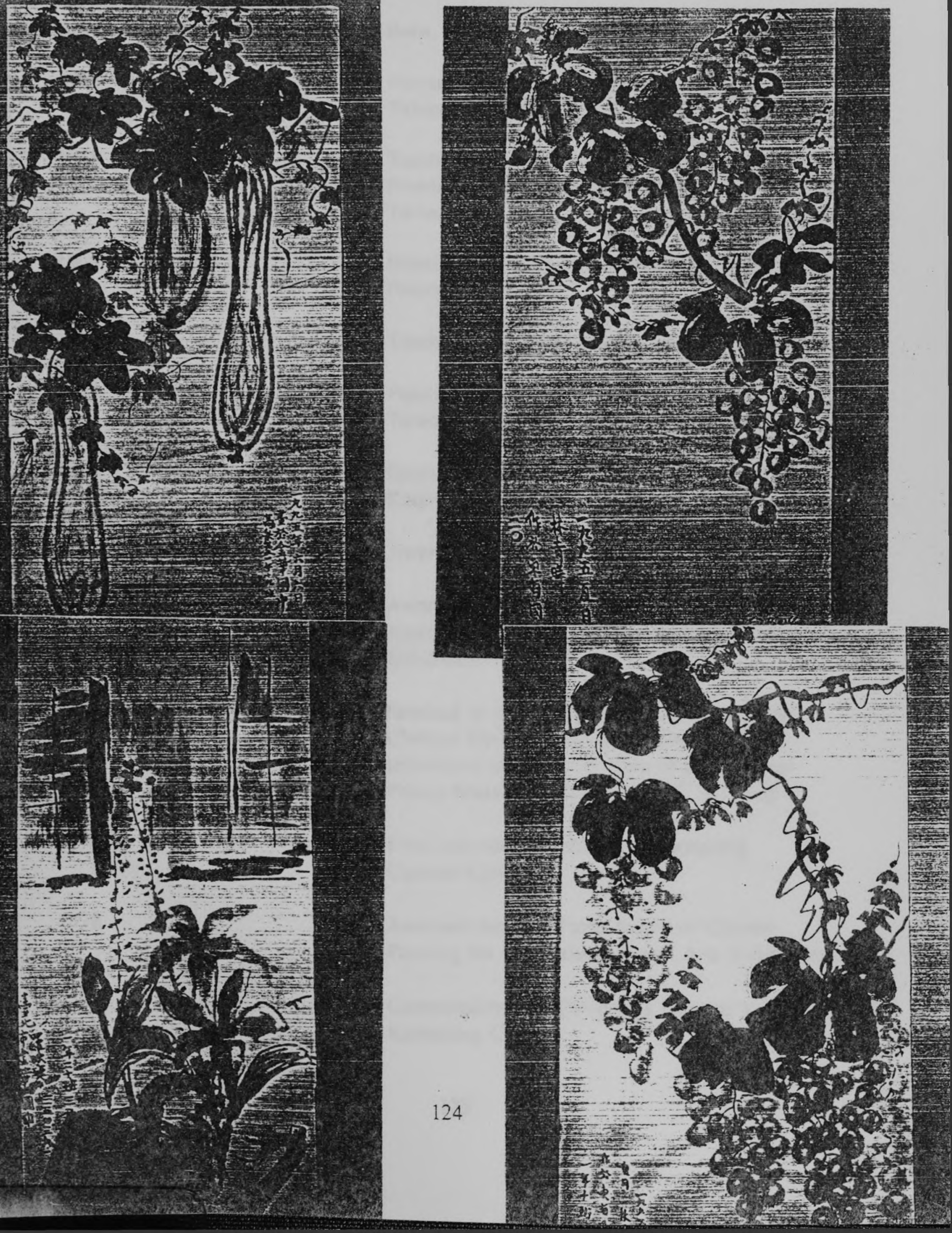
April 1, 1945

1963

1968

1969

1973

1974

1975

1976

1977

1978

Born, Chia-Yi. Taiwan, ROC

Provincial Tainan Teachers Normal School

Tainan, Taiwan

Teachers Department

Provincial Tainan Teacher College

Tainan, Taiwan

Painting selected for First Youth Calligraphy and Painting Exhibition

Teachers' Award in Guiding Children' Painting

Painting selected for the Exhibition at Southern

Taiwap

Special Award for Calligraphy Exhibition in Kaohsiung. Taiwan

Awarded the 1975 Youth Painter award

Awarded the Chinese Painting Award for the SinoJapanese Good-Will Calligraphy and Painting Exhibition

Selected as one of three students to study the Chinese Painting and Calligraphy mounting techniques of Mr. C. J. Chiu of the National Palace Museum with Professor C. B. King

First Individual Exhbition at Kaohsiung Cultural Center

Awarded the Fine Piece Award of Chinese

Painting for the National Youth Arts Exhibition

Commissioner for Children's Painting at Kaohsiung City 
Held the second Individual Exhbition at Kaohsiung Cultural Center

Held the third Individual Exhibition at Missouri

State University

Held the fourth Individual Exhbition at Missouri State University

M.A.

Northeast Missouri State

1986-1991

Director, Office of General Affairs

National Taiwan Normal University

1988

Counselor of the Research Center for Humanities National Taiwan University for charcoal drawing, Chinese landscape, flowers and birds. and pointing mounting

1988-present

Appointed Appraisal Commissioner for books on: Arts and Crafts Materials, Arts and Crafts Design. Basic Theory on Arts and Crafts and the Art of Mounting

1989

Faculty and Staff Leisure Activity Exhbition. Taiwan Normal Univeristy Appointed Counselfor for Dan-Chin Chinese Painting Club, National Chieng-Chi University

1989-1992

Director and Manager of the Commissary National Taiwan Normal" Univeristy

1990

Faculty and Staff Leisure Activity Exhbition Taiwan Normal University. 
Awarded Fine Piece Award for the Internation Chinese Painting Campaign. Canada

Teacher and Students' Painting Exhibition Hsin-Sheng Arts Gallery

Fifth Individual Peony Creation Exhibition Hsin-Sheng Arts Gallery 